\title{
Potential mechanisms linking nutrition and neuroendocrine control of reproduction in the sheep
}

Adam Bradley Dobbins

West Virginia University

Follow this and additional works at: https://researchrepository.wvu.edu/etd

\section{Recommended Citation}

Dobbins, Adam Bradley, "Potential mechanisms linking nutrition and neuroendocrine control of reproduction in the sheep" (2004). Graduate Theses, Dissertations, and Problem Reports. 2028. https://researchrepository.wvu.edu/etd/2028

This Thesis is protected by copyright and/or related rights. It has been brought to you by the The Research Repository @ WVU with permission from the rights-holder(s). You are free to use this Thesis in any way that is permitted by the copyright and related rights legislation that applies to your use. For other uses you must obtain permission from the rights-holder(s) directly, unless additional rights are indicated by a Creative Commons license in the record and/ or on the work itself. This Thesis has been accepted for inclusion in WVU Graduate Theses, Dissertations, and Problem Reports collection by an authorized administrator of The Research Repository @ WVU. For more information, please contact researchrepository@mail.wvu.edu. 


\title{
Potential Mechanisms Linking Nutrition and Neuroendocrine Control of Reproduction in the Sheep
}

\section{Adam Bradley Dobbins}

\author{
Thesis submitted to the \\ School of Medicine at \\ West Virginia University \\ in partial fulfillment of the requirements \\ for the degree of
}
Master of Science
in
Physiology
Dr. Stanley M. Hileman, Ph.D., Chair
Dr. Robert L. Goodman, Ph.D.
Dr. John M. Connors, Ph.D.

Department of Physiology and Pharmacology

\section{Morgantown, WV}

2004

Keywords: Sheep, IGF-1, Thyroid Hormone, Neuropeptide Y, Luteinizing Hormone, Steroid Negative Feedback 


\section{ABSTRACT \\ Potential Mechanisms Linking Nutrition and Neuroendocrine Control of Reproduction in the Sheep}

Adam B. Dobbins

Nutrition and reproduction are linked in that the nutritional status of an individual influences its reproductive performance, i.e. an individual in negative energy balance will have decreased ability to reproduce. The mechanisms in which nutrition influences reproduction are not understood. My data suggest that reductions in lutenizing hormone secretion resulting from photoperiod-induced increases in sensitivity to testosterone negative feedback may be mediated, at least in part, by elevated neuropeptide Y (NPY), a hypothalamic neuropeptide shown to alter gonadotropin releasing hormone release and potently affect food intake. The results from my second study support our hypothesis that the growth hormone mediated hormone, insulin like growth factor-1 (IGF-1) increases thyroid hormone levels during food deprivation. Furthermore, results from these experiments show that food deprivation has a greater impact on males than females and that the thyroid hormone response to IGF-1 during food deprivation is much greater in females. Though there are likely many humoral and neuroendocrine factors that must act together to coordinate the reproductive response to nutrition, our studies with NPY and IGF-1 have begun to examine some potential mechanisms linking nutrition and neuroendocrine control of reproduction in the sheep 


\section{TABLE OF CONTENTS}

\section{Chapter 1: Review of Literature}

1) Seasonality in Female and Male Sheep

a) Reproduction

1. Reproductive Endocrine Axis

2. Seasonal changes in GnRH/LH Release

3. Mechanisms of Steroid Negative Feedback

b) Food Intake

1. Influence of Photoperiod

2. Role of Steroids

2) Influence of Nutrition on Reproduction

a) Puberty, Postpartum Interval, Estrous cycle expression 10

b) Site of Influence 17

c) Male-Female Differences 18

d) Theories concerning the link between nutrition and reproduction 21

3) Potential Metabolic Signals linking Reproduction and Nutrition

a) IGF-1 23

1. IGF-1 and Growth/Nutrition 24

2. IGF-1 and Reproduction 25

b) Insulin $\quad 27$

c) Glucose $\quad 28$

d) Thyroid Hormone $\quad 30$

e) Glucocorticoids $\quad 32$

f) Leptin $\quad 34$

4) Central Integration of Reproductive and Nutritional Cues

a) Hypothalamus 38

1. NPY and Food Intake $\quad 39$

2. NPY and Reproduction $\quad 40$

3. Seasonal Changes in NPY 41

4. Sex Differences 42

b) Brainstem 43

Chapter 2: Neuropeptide Y Gene Expression in Male Sheep: Influence of Photoperiod and Testosterone

1) Abstract 45

2) Introduction 46

3) Materials and Methods $\quad 47$

4) Results $\quad 50$

5) Discussion 51 
Chapter 3: Influence of Insulin-like Growth Factor-1 (IGF-1) on Thyroxine (T4) and Triiodothyronine (T3) in Food-Deprived Male and Female Sheep
1) Abstract
58
2) Introduction
59
3) Materials and Methods
61
4) Results
64
5) Discussion
67

Chapter 4: Literature Cited

81 


\section{CHAPTER 1: REVIEW OF LITERATURE}

\section{1) Seasonality in Female and Male Sheep}

\section{1.a.) Reproduction}

\section{1.a.1.) Reproductive Endocrine Axis}

Control of reproductive function in mammals involves endocrine interactions among the hypothalamus, anterior pituitary, and gonads. Gonadotropin releasing hormone $(\mathrm{GnRH})$ is the primary neurohormone regulating reproductive function. GnRH neurons, derived from the olfactory placode during development, are found spread throughout the preoptic area (POA) and medial basal hypothalamus $(\mathrm{MBH})$ in sheep (14), as well as in rodents (5). These neurons are not located in any one particular nuclear region of the forebrain or hypothalamus. Among various species $40-50 \%$ of GnRH neurons are thought to terminate in the median eminence $(1 ; 3-8)$. With regard to the sheep, the majority of GnRH neurons are found in the medial POA with a significantly greater number of neurons projecting from here to the median eminence than from other areas, indicating that the POA likely gives rise to the majority of GnRH that is released (3). GnRH is released in a pulsatile fashion into hypothalamo-pituitary portal blood leading to the pulsatile release of luteinizing hormone (LH), and a relatively continuous release of follicle stimulating hormone (FSH), from the anterior pituitary gland. Both LH and $\mathrm{FSH}$ are involved in regulating production of gametes and hormones in males and females. The frequency of GnRH pulses, and consequently LH pulses, is the code used by the nervous system to control testicular/ovarian function (9). Due to its rapid breakdown in the peripheral vasculature, GnRH is only measurable in the portal blood, and is therefore very difficult to assess. Thus, LH is often used as a peripheral marker to 
reflect the activity of a neural oscillator, or pulse generator, that produces episodic secretions of GnRH. At least in the sheep, each LH pulse is preceded by a GnRH pulse (10).

Release of GnRH and LH/FSH is impacted greatly by circulating gonadal steroids. Testosterone is predominantly released by the testes and can be converted into dihydrotestosterone (DHT) via the enzyme 5- $\alpha$-reductase, or into estradiol via the enzyme aromatase. DHT and estradiol feed back at the hypothalamus to decrease GnRH release and at the pituitary to decrease the response to GnRH. In the female, LH and FSH stimulate ovarian production of estradiol and progesterone. Progesterone and low levels of estradiol act to inhibit GnRH release and alter pituitary sensitivity to GnRH. However, high levels of estradiol cause the pre-ovulatory GnRH and LH surge. Sensitivity to steroid negative feedback changes throughout the year, so that GnRH and LH secretion is relatively high during the breeding season and decreased during the nonbreeding season.

\section{1.a.2.) Seasonal changes in $\mathrm{GnRH} / \mathrm{LH}$ Release}

Sheep are seasonal breeders with initiation of reproductive activity occurring during the shortening days of late summer and fall, and terminating during the lengthening days of late winter or early spring $(11 ; 12)$. These seasonal swings in reproductive activity are due largely to changes in pulsatile patterns of $\mathrm{GnRH}$, and thus $\mathrm{LH}$, secretion. The alterations in patterns of $\mathrm{GnRH}$ and $\mathrm{LH}$ release are due to an interaction of daylength and steroid negative feedback (13-17). Based on the expression of estrous cycles, female sheep demonstrate an abrupt change from breeding season to non-breeding season. In ewes that have been ovariectomized and implanted with 
estradiol, GnRH and LH secretion exhibit a high frequency pattern of release during the breeding season, whereas during the nonbreeding season, GnRH and LH secretion is characterized by a low-frequency pattern of release. Within the breeding season of ewes, pulses of $\mathrm{LH}$ and $\mathrm{GnRH}$ are infrequent during the luteal phase of the estrous cycle, reported at 0-2 pulses over a 6-hour period (18). This is due to the presence of a progesterone-producing corpus luteum at the site of ovarian rupture. During pregnancy, high progesterone acts as an inhibitor of LH secretion (19;20), inhibiting estrous cycles and allowing the individual to maintain the pregnancy. A low level of estradiol is maintained throughout the luteal phase, which acts to enhance the inhibitory effects of progesterone; estradiol reduces pulse amplitude, while progesterone reduces pulse frequency (21). During the follicular phase, GnRH and LH pulse frequency increases dramatically to 8 pulses per 6 hour period following withdrawal of progesterone during luteolysis (18). During this period, estradiol is a weak inhibitor of LH release and does not suppress LH pulse frequency (13), but rather increases pulse frequency (22). During the anestrous period, however, estradiol is an extremely powerful inhibitor of LH pulse frequency $(23 ; 24)$ and contributes to decreased pulsatile GnRH and LH release (25), which drops to a frequency of 1-2 pulses per 12 hour period (18). These changes in estradiol negative feedback are, in large part, responsible for seasonal variations in LH release.

Males also show seasonal alterations in fertility, though changes among seasons are more gradual than in females. Lincoln (26) reviewed the seasonal changes in reproduction in males of the Soay breed of sheep. There is a seasonal cycle in the blood concentrations of FSH with a marked increase from June to September, consistent with 
its role in stimulating spermatogenesis and growth of the testis. The testes are fully enlarged in October at the beginning of the rut, when most matings occur in the wild. In other, less seasonal breeds, like Hampshire and Suffolk, no seasonal change in LH is reported $(27 ; 28)$. Furthermore, seasonal changes do not occur in the same time frame for males and females. LH concentrations rise earlier in the fall in adult males than in adult females (29), possibly due to differing sensitivity to estradiol and testosterone between the two sexes. Nonetheless, comparable circannual changes in gonadal feedback exist in the male as in the female. Entry into the breeding season is governed by an increase in pulsatile LH secretion as a result of a reduced response to testosterone negative feedback in rams. Testosterone is converted into estradiol via aromatization and into DHT via 5- $\alpha$ reduction and the relative contribution of each of these metabolites for controlling GnRH release is unclear. Estradiol is inhibitory to LH at physiological concentrations in steers (30) as well as sheep $(31 ; 32)$ and blockade of the conversion of testosterone to estradiol increases LH secretion in male sheep (33). Castrated rams given DHT demonstrated a lack of responsiveness of $\mathrm{LH}$ release to exogenous $\mathrm{GnRH}$ when compared to untreated animals (34). DHT appears to be of physiological importance since blocking 5- $\alpha$ reductase activity significantly blunts the ability of testosterone to inhibit pulsatile LH release (35), possibly acting at the pituitary since there is a large amount of 5- $\alpha$-reductase activity (36) and a high number of DHT binding sites (37) in male and female calf pituitary glands.

Photoperiod provides input to control the timing of changes in steroid sensitivity. A switch from long to short days results in a progressive decline in LH concentrations, while a switch back to long days caused the opposite response in LH (17). These 
observations lead to the conclusion that the inhibitory photoperiod of anestrous enables estradiol and/or DHT to act within the brain to depress LH pulse frequency. This action is significantly diminished by the inductive photoperiods of the breeding season (38).

\section{1.a.3.) Mechanisms of Steroid Negative Feedback}

The neural mechanisms that mediate steroid negative feedback on gonadotropin release are not fully understood. In male sheep, testosterone, or its metabolites like DHT and estradiol, acts primarily, although not exclusively, on the brain to suppress GnRH pulse frequency. Specifically, castration leads to an increase in GnRH pulse frequency, yet LH pulse frequency does not increase significantly (39), whereas testosterone replacement reduces GnRH pulse frequency, yet has a marginal effect on pituitary response to exogenous GnRH (40). Evaluation of pituitary responsiveness across various times of the year leads to the conclusion that testosterone does act directly on the pituitary to modulate the response to $\mathrm{GnRH}$, yet since $\mathrm{LH}$ pulses still mirror $\mathrm{GnRH}$ pulses, it is still maintained that shifts in LH pulse frequency reflect parallel changes in GnRH pulse frequency rather than profound changes in pituitary responsiveness to GnRH (27). The neural sensitivity to the negative feedback action of testosterone as well as circulating concentrations of testosterone vary greatly with stage of the annual reproductive cycle (27). Thus it is likely that the relative effect of testosterone on the pituitary versus brain also varies with stage of the annual reproductive cycle (41).

Cells containing estrogen receptors (ER) in the brain of the ewe are distributed throughout many areas of the brain and hypothalamus, including the medial POA, anterior hypothalamic area, ventromedial septum, bed nucleus of the stria terminals (BNST), ventral medial nucleus (VMN), and arcuate nucleus (Arc) (42-44). Similar to 
guinea pigs, but not to rats or monkeys (45), ER-immunoreactive cells have been detected in the supraoptic nucleus (SON) of ewes within its dorsomedial aspect (43). Only very few ER-immunoreactive cells are found in the paraventricular nucleus (PVN). In ewes, the highest density of ER-immunoreactive cells is found in the Arc (42), and ER have been reported in the anterior pituitary gland (46-48). Blache et al. (42) used brain sections from both ovariectomized and estradiol-replaced ovariectomized ewes and found no effect of estradiol on ER-positive cell density in the POA, VMN, or Arc. However, progesterone administration did result in the detection of greater numbers of ERimmunopositive cells in the VMN of ovariectomized ewes (42). In the VMN of male sheep there are substantially fewer ER $\alpha$ containing cells and less ER $\alpha$ mRNA per cell than ewes (49). In addition, a similar finding for the mPOA and VMN has been reported for rats $(50)$. The more recently discovered estrogen receptor- $\beta(\operatorname{ER} \beta)$ is present in the Arc, VMN, POA, SON, and PVN within the hypothalamus (49;51), though its role in mediating various aspects of the GnRH response to estradiol remains unclear (52).

In general, the overall distribution of androgen receptor (AR)-containing cells in males is very similar to that of ER in ewes, with the largest numbers of ARimmunopositive cells found in the medial POA, VMN, and Arc (45). In the VMN, ARpositive cells are located more medially in the dorsomedial division whereas estrogen receptors are not found in this particular subregion (45). AR-positive cells are detected throughout the Arc, but at a much lower density compared to ER-containing cells in ewes (45). A very similar distribution has been shown for AR-containing cells in rat hypothalami (53). 
GnRH neurons in female and male rats do not possess ER $\alpha(54 ; 55)$. Studies with ovariectomized ewes have similarly demonstrated that GnRH neurons throughout the hypothalamus do not display ER immunoreactivity $(43 ; 56)$. Likewise, GnRH neurons of rats do not possess AR (57). A consistent observation from these double-labeling studies is that GnRH neurons are usually surrounded by ER $\alpha$ and AR-immunopositive cells $(45 ; 55 ; 56)$. Based on these studies, it seems likely therefore that steroid-receptive interneuron populations mediate the influences of estradiol and androgens (i.e. testosterone and DHT) upon GnRH neurons.

In the absence of estradiol in the female sheep (58), or in the absence of testosterone in the male sheep $(17 ; 59)$, a relatively small photoperiod-induced decline in LH pulse frequency and an increase in pulse amplitude still occurs when animals are exposed to natural or artificial long-day photoperiods. Larger steroid-independent suppression of circulating gonadotropin concentrations during inhibitory photoperiods are apparent in other species such as red deer hinds (60), and snowshoe hare bucks and does (61). These steroid-independent rhythms are often considered to be the result of variations in an underlying direct photoperiodic drive to gonadotropic output $(58 ; 61)$, which is further modified by steroid negative feedback (38). Lincoln (17) reported similar results for rams under controlled, artificial lighting. Other hormones, such as thyroid hormones (62), may play a role in these steroid independent changes in LH.

\section{1.b) Food Intake}

\section{1.b.1.) Influence of Photoperiod}

Many species living in temperate and cold climates express profound seasonal changes in voluntary food intake (VFI) and body weight. There is evidence that long- 
term cycles in VFI, growth, and pituitary hormone secretion persist in sheep living under constant photoperiod and environmental conditions (63). This supports the view that the seasonal cycle in VFI is generated endogenously. Under natural conditions, the response to the annual cycle in day length acts to entrain the period of endogenous rhythm to a period of exactly 12 months in order to time the anabolic growth phase to summer when food is most abundant and the catabolic anorexic phase to winter when food is scarce $(64 ; 65)$. Artificial conversion from short days to long days provokes an increase in VFI and exposure to alternating 3-6 month periods of long and short days drives the cycle in VFI and body weight (65). These photoperiod-induced changes are controlled, in large part, by mechanisms residing within the hypothalamus.

Many neuropeptides that have been isolated in the hypothalamus are capable of influencing VFI. Orexigenic peptides, such as neuropeptide Y (NPY) and agouti-related peptide (AgRP), are up-regulated under long days in sheep (65) and hamsters (66) in association with an increase in appetite in males. An increase in arcuate NPY has been reported in females on a long day photoperiod (64). Barker-Gibb et al. (67) reported that seasonal changes in NPY in the ewe are not dependent on steroids. In the male, expression of the proopiomelanocortin (POMC) gene is reduced under long days in testosterone-implanted castrate sheep (68) and hamsters (66), while being increased during long days in ovariectomized ewes (64). One potential reason for these differences could be due to gender. Alternatively, NPY and POMC may be regulated differently in the context of season and steroid milieu. Orexigenic melanin concentrating hormone $(\mathrm{MCH})$ is reduced under long days in males, but changes in expression may be linked to its role in regulating the reproductive axis more so than regulating VFI (65). It is 
important to note that POMC serves as a precursor to both anorexic $\alpha$-melanocytestimulating hormone $(\alpha \mathrm{MSH})$ and orexigenic $\beta$-endorphin so its role in controlling food intake is more complicated (69).

\section{1.b.2.) Role of Steroids}

Gonadal hormones are involved in the regulating food intake in rats $(70 ; 71)$, hamsters (72), and mice (73). Androgens generally act as anabolic agents that increase food intake and lean mass, whereas estrogens are catabolic and decrease food intake and body weight. Male rats that are orchiectomized at birth exhibit significant decreases in rate of body weight gain with a slight or no decrease in daily food intake and testosterone administration reverses the effect on body weight (70;73-82). Orchiectomy has no detectable effects on the quantity of food ingested in adult rats until after about 4 weeks of age, by which time lean body mass has also decreased (83). Low dose androgen administration increases food intake in rats, whereas higher doses decrease food intake (83). Treatment with androsta-1,4,6-triene-3,17-dione, an aromatase inhibiter, increased food intake and weight gain when administered with high doses of testosterone (84). This supports the idea that dose dependent effects of testosterone result from the aromatization to estrogens when testosterone is given in high doses.

In the female, estradiol significantly influences energy balance by reducing food intake. Ovariectomy produces an immediate increase in feeding in rats and mice, and estradiol treatment is sufficient to normalize both feeding and body weight (85-88). In postmenopausal women, there is an increase in total percent body fat. Hormone replacement attenuates these fat gains (89). During estrous, ovariectomy eliminates an estrous-induced decrease in food intake (90). Several studies have reported an inhibitory 
effect of estradiol on NPY mRNA or peptide levels in female rats (91-94). Decreasing NPY input could be one mechanism by which estradiol helps to decrease food intake.

NPY levels are higher in males than in females. Sexually dimorphic NPY levels may, at least in part, be due to the metabolism of testosterone to dihydrotestosterone (DHT). While the influence of DHT on NPY has not been directly assessed, like testosterone, DHT prevents cold-induced loss of body weight (95), increases body mass (76), and increases food intake $(70 ; 96)$. This raises the possibility that DHT may mediate, at least in part, metabolic responses involving NPY that are influenced by testosterone. Indirect evidence also indicates that in human subjects some of the effects of gonadal steroids on food intake and body weight may be mediated to some extent by influencing serum leptin levels and hypothalamic leptin receptor gene expression (97).

\section{2) Influence of Nutrition on Reproduction}

Producers have long known the importance of proper nutrition for increasing conception rates and decreasing postpartum intervals. The mechanisms whereby nutrition influences reproduction are not completely understood. In the following section, the influences of nutrition on three hallmarks of reproduction (puberty, postpartum return to breeding, and expression of estrous cycles) will be discussed, along with potential mechanisms that link nutrition and $\mathrm{GnRH} / \mathrm{LH}$ secretion.

\section{2.a.) Nutritional Influences on Puberty, Postpartum Interval, and Estrous Cycle Expression}

Puberty is the time in life when mature gametes are first produced and individuals become capable of reproducing. This is due to an increase in activity from the 
reproductive endocrine axis, i.e. an increase in $\mathrm{GnRH}$ and $\mathrm{LH}$ release. In the sheep this is the result of a decreased responsiveness of the hypothalamus to estradiol negative feedback. As measured by an increase in LH, puberty occurs earlier in the male lamb than in the ovariectomized female lamb. In the immature female, LH pulse frequency is low and increases typically at $25-35$ weeks in spring born lambs (98). LH pulse frequency is also initially low in the male, but increases to near pubertal levels by 9-11 weeks (99). This sex difference is due to an earlier decrease in response to steroid negative feedback in the males (100). Foster et al. (101) failed to find an increase in the frequency of pulsatile LH secretion in ovariectomized lambs at the time when intact lambs began their first reproductive cycles suggesting that steroid-independent mechanisms are likely not overly important. They also ruled out a major influence of photoperiod in ovariectomized lambs as LH pulse frequency was not influenced by a photoperiod treatment known to delay puberty in gonad-intact sheep. However, insufficient nutrition can delay the peripubertal rise in pulsatile LH secretion that normally occurs during the stimulatory daylengths of autumn (102). Still, photoperiod may play a modulatory role in the onset of puberty. In males, a pre-pubertal increase in gonadotropins drives increasing testosterone and spermatogenesis to achieve a level of fertility approximating that of the adult male during the nonbreeding season (103). Once testicular function approaches a level similar to that of the seasonally suppressed adult male, subsequent sexual maturation to reach full fertility is more photoperiod-dependent (104).

In other species, a change in hypothalamic sensitivity to estradiol negative feedback does not seem to be a component of puberty onset. Ojeda et al. (105) has 
reviewed the control of puberty in the female rat. In this model the CNS appears to play a pivotal role. In the time leading up to puberty, there is a centrally driven, gonadalindependent diurnal change in pulsatile LH release. Basal release of LH and the magnitude of LH secretory episodes increase markedly in the afternoon. These changes stimulate the ovary to produce more estradiol which then evokes minisurges of LH secretion that in turn further stimulate ovarian development and steroidogenesis. The increase in ovarian steroids, especially estradiol, helps lead to the preovulatory discharge of $\mathrm{GnRH}$ which directly promotes the first surge of gonadotropins and ovulation.

As with sheep, GnRH neurons in primates appear to be functionally mature well before the onset of puberty in primates $(106 ; 107)$. In fact, following gonadectomy at $1-2$ weeks of age, there is up to 10 weeks of elevated mean LH levels observed in both the male and female monkey, though the increase is more dramatic in the male (108). The postnatal increase in LH release ends due to central inhibition rather than due to steroid negative feedback $(109 ; 110)$. Richter and Terasawa (111) reviewed the mechanisms that are responsible for maintaining gonadotropins at a low level before puberty in the rhesus monkey, and how these inhibitory mechanisms are diminished at puberty. Gammaaminobutyric acid (GABA), an inhibitory neurotransmitter, along with possible involvement from additional factors such as NPY, are involved in inhibiting GnRH release from the hypothalamus. At the onset of puberty in the rhesus monkey there is a postulated decrease in inhibitory GABA input and an increase in levels of the excitatory neurotransmitter glutamate, which allows for an increase in LH pulse frequency and the initiation of estrous. NPY and its role in puberty in primates appears to be sex specific. In the female rhesus monkey there is an increase in NPY mRNA along with the increase 
in GnRH, indicating NPY may be stimulatory to GnRH (111). In the male there is a decrease in NPY mRNA along with an increase in GnRH mRNA suggesting that NPY is inhibiting GnRH (112).

Regardless of the strategy whereby puberty is attained, onset of puberty is delayed in all species whenever a female is in negative energy balance (113). Furthermore, the onset of fertility is also more closely associated with body size and food intake than with chronological age in females whose growth has been retarded by food restriction (114). Foster and Olster (102) demonstrated that ewe lambs fed to maintain their weaning weights were anovulatory at a time when growing lambs became pubertal. McShane and Keisler (115) demonstrated that hourly injections of LH in underfed lambs induced follicular growth, LH surges of normal amplitude, and ovulation, indicating that the hypothalamus is likely involved in decreased reproductive function during times of reduced nutrition. Indeed, GnRH secretion is inhibited in undernourished lambs (116). These studies suggest that undernutrition acts to inhibit the increase in GnRH secretion that is required for puberty to occur. LH pulses and LH surges have been induced in peripubertal female lambs by administration of GnRH (117), showing that the pituitary and the ovary are not limiting in pubertal develment. GnRH neurons also seem mature prior to puberty as evidenced by stimulation of LH release using N-methyl-D-aspartate, a glutamate analog that triggers GnRH release (117). Refeeding is known to increase circulating levels of gonadotropins and trigger onset of puberty and expression of estrous cycles in growth-restricted animals, and exogenous administration of GnRH pulses to growth-restricted prepubertal rats will induce estrous cycles (118). 
Like puberty, the duration of the postpartum interval, or the time period following parturition when reproduction is inhibited, is also influenced by nutrition. Postpartum anestrous is a transition period during which the functional hypothalamic-pituitaryovarian-uterine axis recovers from the previous pregnancy. Time is necessary for uterine involution to begin, for anterior pituitary LH stores to be replenished, and for waves of ovarian follicular growth to resume (119). During pregnancy, high circulating estradiol concentrations inhibit the pulsatile release of GnRH from the hypothalamus. The dramatic fall in circulating estradiol concentrations at the time of parturition leads to an immediate postpartum increase in FSH secretion, which initiates a wave of ovarian follicular growth within two weeks postpartum in cattle (120) and in sheep (121). However, follicle maturation and ovulation do not occur unless there is a concomitant increase in LH pulsatility.

Duration of postpartum anestrous is affected by four major factors: suckling, age, season, and nutrition (119). Suckling increases the duration of postpartum anestrous and old or first pregnancy animals often rebreed more slowly. Restriction of dietary energy late in the prepartum period or early in the postpartum period reduces the number of animals returning to estrus within a well-defined breeding season. These effects are apparently attributed to a failure to develop preovulatory ovarian follicles (122). Most studies examining the postpartum interval have been conducted in cattle. Increasing energy intake after parturition in thin heifers shortened the postpartum interval (123) and increased circulating LH concentrations (124). Body condition score at parturition is positively correlated with follicular development early post partum (125) and pituitary LH content at 30 days postpartum (126). 
Most ewes give birth at the end of their natural breeding season when photoperiod is inhibitory to the reproductive axis, making the postpartum period less of a concern in this species. Nonetheless, a limited body of literature exists concerning postpartum intervals in sheep. Autumn lambing ewes maintain the opportunity to re-breed during the fall breeding season. Economically this could be beneficial if a second lamb crop can be produced in one year, or if the producer has a high priced niche market during the holiday season. Mandiki et al. (121) have shown November lambing ewes have a shorter postpartum interval than July lambing ewes. Lishman et al. (127) did report that restricting food intake for 84 days postpartum in ewes that lambed in the autumn reduced the percentage of ewes returning to estrous. Since dietary energy restriction impairs pulsatile LH secretion in ovariectomized ewes, it seems reasonable to suggest that energy restriction would delay or prevent postpartum re-breeding of ewes via alterations in $\mathrm{GnRH} / \mathrm{LH}$ release.

Similar to puberty and postpartum return to breeding, inadequate nutrtion also inhibits the expression of estrous cycles. For example, severely food deprived rats have lower pituitary, ovarian, and uterine weights (128). Restricted feeding for a prolonged period affects ovulation rate, timing of the estrous cycle, and ability to reproduce in rodents $(128 ; 129)$. Tropp and Markus (130) have shown that in Fischer 344 and Brown Norway rats moderate food restriction (to produce a 15\% drop in body weight) can cause cessation of estrous cycles as early as day one following the onset of food deprivation. Ad libitum feeding restored estrous cycles in these animals within 2-4 days. In this study, Sprague-Dawley and Long-Evans rats were more resistant to the effects of mild 
food restriction than Fischer 344 and Brown Norway rats, indicating that, in rodents, strain-dependent differences in response to food restriction exist.

Restricted feeding and acute fasting in heifers inhibit cyclic ovarian function and expression of estrous, and prolonged restriction of dietary energy results in cessation of estrous cycles in cattle $(131 ; 132)$. Failure to ovulate occurred 32 weeks after initiation of food restriction to cause a $1 \%$ loss of body weight per week $(22 \%$ average weight loss over treatment period was actually achieved) (133). Anovulation was likely due to the observed significant drop in LH and FSH levels. In addition, circulating IGF-1, insulin and glucose levels were reduced in restricted animals. The potential role of these factors in mediating the influences of nutrition on reproduction will be discussed later.

Adult ewes maintained on low planes of nutrition also exhibit reduced ovulation rates (134), a response attributed to reduced ovarian follicular development (135) rather than to alteration of the pre-ovulatory surge of LH. Effects on follicular development could result from disruption of pulsatile LH release, and indeed ovariectomized ewes maintained on a low energy diet exhibit fewer LH pulses and lower mean LH concentrations in serum (136).

Flushing, or increasing energy intake at least one estrous cycle prior to breeding, in ewes with low body condition is one way of increasing conception rates and the number of offspring conceived (134). Ovulation rate in the ewe is influenced by both body condition at mating and the pre-mating level of nutrition $(137 ; 138)$. These two phenomena are clearly related since long-term changes in pre-mating level of nutrition will change the body condition of the ewe at mating (134). The number of eggs ovulated, 
and ultimately the number of lambs born, can be increased in underconditioned ewes by flushing (139).

\section{2.b.) Site of Influence}

As discussed above, although GnRH release is inhibited during undernutrition, GnRH neurons themselves appear to be functionally normal during undernutrition. The finding that pulsatile LH secretion can be suppressed in gonadectomized animals suggests that food restriction can act independently of steroids to suppress GnRH release. However, evidence exists to suggest that food restriction enhances the ability of estradiol to inhibit pulsatile LH secretion. The systems underlying this response are unknown. A number of neural systems have been shown to express ER $\alpha$ and/or AR and also influence GnRH release. Such potential mediatiors of steroid action on GnRH release include galanin $(140 ; 141)$, classical neurotransmitters such as serotonin (142), excitatory (143) and inhibitory amino acids (144), and local growth factors (145). Some of these neural mediators of steroid feedback are listed in Table 1 at the end of chapter, along with their action on GnRH and LH secretion.

NPY is one particularly attractive candidate that may be involved in mediating steroid negative feedback on GnRH release during undernutrition. NPY, steroid negative feedback and GnRH release during inadequate food intake could be linked for the following reasons: NPY alters GnRH and LH release (67;146-148), NPY-containing neurons synapse directly onto GnRH neurons (149), NPY neurons coexpress ER $\alpha$ (150), and NPY levels are markedly influenced by nutrition (151). This neurotransmitter will be discussed in greater detail later in this section. 


\section{2.c.) Male-Female Differences}

There are several differences between males and females in the way they respond to changes in nutrition. Hoyenga and Hoyenga (152) have proposed that due to gender specific evolutionary selection pressures, female mammals have evolved a greater capacity to conserve energy than males. Accordingly, food restriction has been reported to have a greater and more permanent effect on physical growth in males than females (152). In rats subjected to complete starvation for six days, body mass loss was similar following starvation, but males lost a greater percentage $(16 \%)$ of their body mass as protein than did females $(8 \%)$. The ratio of lipid to protein lost (g) was 1.16 for males versus 3.26 for females (153). Taken together these data suggest that females are more adept at conserving energy during periods of low fuel availability. Differences are also observed when animals have access to excess calories. Hileman et al. (154) show that male mice fed a high fat diet gained weight much more rapidly than did female mice, with increased weight gain being evident by 4 weeks in males. Females, however, did not show appreciable additional weight gain until week 8 , and this was largely due to an increased response of one female to the high fat diet. Females appeared to be more able to compensate by decreasing intake, either in total grams of food ingested or kilocalories eaten, than were the males on a high fat diet.

Several factors that are involved in regulating body weight show sexual dimorphism. There is a clear effect of sex and season on the satiety functions of leptin in sheep. During the shortening days of fall, leptin was ineffective as a satiety agent in either sex. During the lengthening days of spring, however leptin was able to suppress appetite to a greater degree in female than in male sheep (69). There is also a gender 
difference in the development of leptin resistance in mice following exposure to a highfat diet. Males placed on a high-fat diet for 5 weeks did not lose body fat in response to physiological doses of leptin infused peripherally. In contrast, female mice on the same treatment, as well as males and females fed the high-fat diet for 15 weeks, lost body fat during the leptin infusions (155). There are conflicting data concerning leptin in males and females. In rats and mice, leptin levels have been reported to be higher in either males (156) or females $(97 ; 156 ; 157)$. In humans, females consistently have higher leptin levels than males (158). There is less of a decrease in leptin due to starvation in females compared to males (157), though the mechanisms underlying these sex-related differences remain unclear.

In response to fasting, there is a greater reduction in total $T_{4}$ in females than in males, though both sexes showed a decrease in $\mathrm{T}_{4}$ following starvation (159). A reduction in $T_{4}$ is consistent with previous studies in both males (160) and females (161) although direct comparisons between sexes were not performed. Corticosterone levels following fasting increased to a greater extent for females than for males (159), possibly due to a more robust metabolic response to food deprivation in females. It is also possible that starvation may be more stressful for females. Sex-related differences in the response to stress have been reported (162), and Born et al. (163) have proposed that, at least in humans, young females are more sensitive to corticosterone releasing hormone (CRH) since higher $\mathrm{CRH}$ levels were required to elicit the same corticosterone levels in young males. The magnitude of neuroendocrine and metabolic responses to hypoglycemia is reduced in women compared with men $(164 ; 165)$. These data suggest that females are less insulin sensitive compared to males, at least under hypoglycemic 
conditions (165). Circulating IGF-1 concentrations were greater in prepubertal male sheep than prepubertal female sheep $(166 ; 167)$. Accordingly, greater concentrations of plasma IGF-1 were found in rams than in ewes around the time of puberty (168), but in this study sex differences before puberty were not detected.

As mentioned earlier, a sex-dependent difference in the timing of puberty exists for male and female sheep. These differences arise because the time course of gametogenesis and the metabolic investments in reproduction can be quite different in the two sexes. It takes longer for gametogenesis in males so there must be a time difference in order for them to be prepared to breed at the same time as the females. As mentioned earlier, the pubertal increase in LH secretion occurs in male sheep at about 10 weeks and in female sheep at about 30 weeks of age (169). This is due to a sex-dependent difference in responsiveness to inhibition of GnRH secretion by estradiol. Thus, the period of high responsiveness to estradiol lasts three-fold longer in prepubertal female sheep than in male sheep (100). The stimulatory feedback mechanism by which estradiol induces LH surges is also sexually differentiated in sheep (32). In castrated adult sheep, treatment with high physiological levels of estradiol promptly suppresses tonic LH secretion in both sexes. However, within 24 hours this negative feedback response is followed by an LH surge only in females. With regard to seasonal fertility, reproductive activity is highly seasonal in the female sheep, and tends to be all or none, whereas the male remains fertile year-round with relatively less seasonal variation in fecundity and libido (26). Seasonal changes in LH levels do not occur in the same time frame between males and females as LH concentrations rise earlier in the fall in adult males than in adult 
females (29), possibly due to differing influences of estradiol and testosterone between the two sexes.

\section{2.d.) Theories concerning the link between nutrition and reproduction}

The reduction in GnRH and LH pulse frequency observed during dietary energy restriction is dramatic and probably represents the most important means by which undernutrition impairs reproductive activity. Early observations in humans that menarche occurred at a critical level of body fatness led to the hypothesis that body fatness somehow regulates reproductive activity (170). The critical body fat hypothesis is supported by data from a wide variety of species and physiological situations. Body weight is related to mean LH levels and the continued expression of estrous cycles in cattle $(132 ; 171)$ and is correlated with the postpartum interval $(172)$. Because weight loss in adult animals is primarily due to a loss of fat, the reduction in LH pulse frequency associated with prolonged dietary energy restriction or decrease in bodyweight/body condition scores is associated with a reduction in body fatness $(132 ; 136)$. The extent of an animal's energy reserve can also influence the time required for undernutrition to alter the reproductive axis. A two-day fast blocks estrous cycles in lean, but not fat hamsters (173). Thus, it seems plausible that metabolic changes resulting from changes in nutrition and paralleling changes in body adiposity somehow regulate pulsatile LH release.

Body fat could exert its effects on reproduction through an alteration in steroid metabolism (174). Changes in body weight and body fat are associated with changes in estradiol metabolism (174) and a high level of androgen aromatization into estradiol occurs in adipose tissue (175). However, impaired tonic LH secretion caused by 
undernutrition is observed in gonadectomized lambs (102), rats (176), and the rhesus monkey (177). If body fatness does alter the activity of the reproductive axis, it is probably through steroid-independent or steroid-modulated mechanisms.

Arguing against a direct role for body fat as a trigger for reproduction are a number of experiments having demonstrated that body fat lacks a direct physiological or biological relationship to the onset of estrous cycles (178). In intensively trained female athletes, menarche is not achieved for months following the attainment of a body weight and composition expected to produce menarche in girls not subjected to such intense training (179). In addition, in some studies puberty and body adiposity can be dissociated (180-183). In addition, when metabolic fuels are supplied, the level of body fat is irrelevant to the maintenance of estrous cycles (173). Instead, the amount of energy stored in adipose tissue could be an important component of overall energy balance, and body fat is probably a marker for the availability of energy for reproductive activity.

The central nervous system still must have some way of detecting changes in the state of an individual's energy balance in order to effect changes in $\mathrm{GnRH} / \mathrm{LH}$ secretion. Some signal(s) must exist to trigger central changes in response to the body's energy state. Blood-borne signals such as metabolites, metabolic fuels, or hormones may serve as a signal to the brain indicating the current energy state of the organism. This signal must have the following characteristics: 1) must be secreted in proportion to body energy status, 2) must have access to the brain, and 3) must effect a predictable response. The following section will examine some possible metabolic and humoral cues that may serve as signals to the central nervous system. 


\section{3) Potential Metabolic Signals linking Reproduction and Nutrition}

\section{3.a.) Insulin-like growth factor 1 (IGF-1)}

Growth is regulated by a number of factors, including environmental signals, health, nutrition, and the genetic potential for growth of an individual. The IGF's are endocrine signals that are critical for normal growth. IGF-1 and IGF-II were first isolated in large-scale purification from a human plasma fraction by Rinderknecht and Humbel (184). They are single chain polypeptides with structural homology to proinsulin. They regulate proliferation and differentiation of a multitude of cell types and are capable of exerting insulin-like metabolic effects. Traditionally, IGF-II is considered to act in this manner pre-natally and IGF-1 to act in young and adult animals. They are produced by most tissues of the body (185-187), are abundant in the circulation, and act in autocrine, paracrine, and endocrine fashions (188). IGF-1 activity is regulated in part by association with binding proteins. IGF-1 and IGF-binding proteins (IGFBPs) are present in the anterior pituitary gland and hypothalamus (189), as well as serum and liver in ruminants (190).

IGF-1 is part of the growth hormone (GH) axis, where GH-Releasing Hormone and Somatostatin are released from the hypothalamus to stimulate and inhibit, respectively, the secretion of GH from the pituitary gland. IGF-1 production by the liver is stimulated by pituitary GH (191) and accounts for about 75\% of circulating IGF-1 levels (192). Circulating IGF-1 feeds back directly on the anterior pituitary to inhibit the synthesis and release of GH (185;193-195). 


\section{3.a.1.) IGF-1 and Growth/Nutrition}

IGF-II is classically thought of as the primary IGF involved in prenatal development. IGF-II is expressed more widely in the embryo (196) and is required for normal embryological development, as IGF-II null mice are $60 \%$ smaller than normal littermates $(197 ; 198)$. However, IGF-1 is also essential for embryological development. IGF-1 knockout mice were not only $60 \%$ smaller than littermates, but displayed severe muscle dystrophy and a high percentage died at birth (199).

Postnatal growth is dependent on normal pulsatile secretion of GH from pituitary somatotrophs. This is particularly important for the accelerated growth seen during the peri-pubertal period. Loss of GH secretion can have important deleterious effects in the maturing organism. GH deficiency results in growth retardation as pituitary-deficient rats did not gain weight or grow in length unless administered GH or IGF-1 (200). In addition to increasing bone length and width and skeletal muscle growth, GH and IGF-1 increase kidney, spleen, and thymus weight, and decrease the weight of epididymal fat pads (201). Despite having markedly increased circulating GH levels, IGF-1 knockout mice are small, suggesting that the major effects of GH on growth are dependent on IGF1 expression (192). In a study of GH deficient rats, administration of human GH (hGH) had no significant effect on relative weights of various organs, whereas a high dose of hIGF-1 had significant stimulatory effects on the kidney and spleen. Both hGH and hIGF-1 increased the relative weight of the adrenals, but this was only significant for hIGF-1 treatment (200).

IGF-1 levels are affected by a lack of dietary energy. Food restriction decreases serum IGF-1 in rodents (202;203), lactating rats (204), ruminants (205), and humans 
(206;207). Furthermore decreased IGF-1 due to food restriction cannot be reversed by administration of GH (206). In guinea pigs, IGF-1 was significantly reduced in animals fed $70 \%$ of their normal diet for a period of 3-4 days (203). There was a significant IGF1 response to a 24-hr food restriction at 5 weeks of age in mouse lines that were bred both for lean body mass increase and fat body mass increase (202). Across other species there is a delay in IFG-1 response to nutrition deficiency. In adult canines it takes 4 days of fasting before a decrease in IGF-1 is seen (208), and in adult humans there is also a decrease in IGF-1 over 9 days of food restriction (206). The decline in IGF-1 concentrations during fasting is due to a decrease in binding of GH to its hepatic receptor, even though GH levels remain constant or even increase. These changes are accompanied by decreases in hepatic IGF-1 and GH receptor mRNA abundance $(209 ; 210)$. Thus, during food restriction, the ability of GH to induce IGF-1 is reduced.

\section{3.a.2. IGF-1 and Reproduction}

Several studies have implicated IGF-1 as a putative metabolic signal linking nutritional state with reproduction. The ability of IGF-1 to act directly on the hypothalamus of immature animals to affect GnRH neuronal activity was first shown in vitro when IGF-1 stimulated GnRH release from the rat median eminence (211). Other in vitro experiments have shown that IGF-1 can have an inhibitory effect on the release of GnRH (212). These researchers applied IGF-1 to a larger hypothalamic area, and postulate that differences may be due to site-specific differences in IGF-1 inputs controlling GnRH secretion. In vivo, female rats exhibited an increase in LH release following i.c.v. administration of IGF-1, apparently due to an increase in GnRH as the response was blocked by administration of antibodies to $\mathrm{GnRH}$ (213). 
IGF-1 may play a role in puberty onset and appears to act at all levels of the HPG axis to influence reproduction. IGF-1 crosses the blood-brain barrier by a specific transport system and is present in the CSF (214). IGF-1 receptors are widely distributed in the hypothalamus and even more abundantly expressed in the pituitary (215). Locally produced IGF-1 augments ovarian granulosa (216) and testicular cells (217) production of steroid hormones. Ovarian IGF-1 has been implicated as a hormone influencing the action of both FSH and LH and almost all known actions of FSH are amplified by IGF-1 (216). Peripherally administered IGF-1 has been shown to stimulate LH secretion in sheep in a dose dependent manner. It seems that IGF-1 is intrinsically stimulatory to LH at low doses, but is inhibitory at higher doses due to hypoglycemia induced by IGF-1 acting at the insulin receptor (218). It seems that estradiol may be important for IGF-1 to inhibit LH secretion. Higher IGF-1 doses (100 and $150 \mu \mathrm{g} / \mathrm{kg}$ ), did not affect LH secretion in ovariectomized ewes but LH levels decreased by $16-22 \%$ in the presence of estradiol (218). In vitro studies have shown that IGF-1 is capable of stimulating LH release from cultured ovine pituitary cells independent of GnRH (215). Circulating levels of IGF-1 are elevated at puberty in rodents $(213 ; 219)$, primates (220), and ruminants (221). The onset of puberty is delayed in heifers immunized against GRF (to decrease serum GH and serum IGF-1 concentrations) at three and six months of age $(188 ; 222)$.

Estradiol has been shown to regulate IGF-1 gene expression in several tissues including the uterus (223). In the ovariectomized rat, estradiol increases IGF-1 mRNA and IGFBP-2 mRNA throughout the anterior pituitary while IGF-1 receptor mRNA expression is unchanged (224). However, castration enhances, rather than abolishes the 
IGF-1 surge which occurs at puberty (219). This could be due to different actions of estradiol vs. testosterone. Collectively, available evidence points to IGF-1 acting as a hormonal factor that can mediate the effects of inadequate nutrition on gonadotropin secretion.

\section{3.b.) Insulin}

Insulin is released from pancreatic $\beta$-cells in response to increased glucose levels and is therefore closely associated with nutritional status in an acute sense. Peripheral concentrations of insulin are directly proportional to the level of food intake (225) and body adiposity (226) and thus may serve as a long-term indicator of nutritional state. Insulin enters the CSF from plasma via a receptor-mediated transport system (227). In a variety of species the brain, and in particular the hypothalamus, contains both insulin and insulin receptors (228). Van Houten et al. (229) showed that insulin receptors are present in the arcuate nucleus and median eminence in rats. The anatomical location of mRNA for insulin receptor in the hypothalamus provides evidence that insulin acts directly to influence hypothalamic function. Indeed, it has long been known that insulin acts centrally to decrease food intake $(230 ; 231)$. Schechter et al. (232) have shown mRNA encoding insulin in the brain of rabbits, indicating a potential role of locally produced insulin.

Insulin also has actions on the reproductive axis. Increases in insulin concentrations in both the peripheral circulation and CSF are associated with increases in gonadotropin secretion (233). In vitro, insulin can stimulate the release of GnRH from rat hypothalamic explants $(211 ; 234)$. Low dose infusion of insulin into the third ventricle of rams fed a restricted diet or diabetic male lambs increases LH pulse frequency to 
values that are similar to controls $(235 ; 236)$. Withdrawal of insulin from diabetic male lambs previously receiving insulin treatment for 24 hours decreases LH pulse frequency whereas re-supplementation of insulin restores LH pulse frequency. After $96 \mathrm{hrs}$ of insulin withdrawal in these lambs, stimulation of LH pulsatility by insulin replacement was exaggerated (237). In contrast, insulin injection into the lateral cerebral ventricle did not increase LH secretion in growth-restricted, hypogonadotropic lambs (238).

Insulin also affects differentiation of porcine granulosa cells by potentiating basal and gonadotropin-induced progesterone production by enhancing FSH-stimulated LH receptor induction (239). Pharmacological concentrations of insulin enhance basal and LH-stimulated progesterone levels and androstenedione accumulation in cultures of porcine thecal tissue (240). These effects may be mediated by insulin binding to IGF receptors. It should be noted that studies using insulin are often difficult to interpret since insulin influences the concentration of many other hormones and metabolic factors, especially that of glucose.

\section{3.c.) Glucose}

Glucose has long been a favored candidate as the metabolic link between nutrition and reproduction (122). Glucose is maintained within a narrow concentration in the blood, as demonstrated by the rapid return of circulating glucose levels to baseline following a postprandial increase. It is the primary metabolic fuel used in ATP production by cells and is the only significant energy-yielding substrate utilized by the brain (241). Thus, glucose levels or availability directly affect activity of the central nervous system (174). In addition, neural activity may also be directly altered by changes in glucose availability since glucose is the precursor for a number of neurotransmitters, 
including glutamate, aspartate, GABA, glutamine, and alanine (174). Glucose is sensed centrally with a large body of evidence supporting a role for the brainstem as a glucosensing region. Lesions to the area postrema (AP) and nucleus of the solitary tract (NTS) in the brainstem block hypoglycemia-induced increases in feeding behavior in rats (242). The AP is outside the blood-brain-barrier, so it is well positioned to sense circulating concentrations. Therefore it is possible that glucose availability is detected in the lower brainstem and the information is relayed to rostral structures controlling both GnRH secretion and food intake. However, there is also evidence to suggest that neurons of the VMH and LHA sense glucose (243). The relative role of the brainstem and hypothalamus in glucosensing has yet to be determined and is a matter of some debate.

Glucose utilization and availability affect the functioning of the reproductive axis, and therefore glucose meets the three requirements for a signal linking nutrition and reproduction. Schneider and Wade (173) demonstrated that blockade of glycolysis in combination with fatty acid oxidation resulted in immediate cessation of estrous cycles in obese hamsters. Given the importance of pulsatile LH secretion in control of reproductive activity, it seems plausible to propose that availability of oxidizable metabolic fuels such as glucose or ketones may impact hypothalamic control of LH release. Nutritionally anestrous cows have lower serum concentration of glucose, along with lower insulin and higher nonesterified fatty acids, than cows on a maintenance diet (244). Inhibition of fat and glucose metabolism depresses pulsatile secretion of LH in female lambs (245). In ewes, insulin-induced hypoglycemia inhibits LH secretion and administration of glucose reverses this effect $(189 ; 246)$ and glucose stimulates LH release in growth-restricted wethers (247). Intravenous infusion of 2-Deoxy-D-Glucose 
blocked the expression of estrous behavior and ovulation in cows (248) and reduced the magnitude of estradiol-induced surges of LH in anestrous sheep (249). In addition, in rats and lambs, 2DG decreases LH pulse frequency to values typically seen in undernourished animals $(250 ; 251)$. Treatment with 2DG also prevented the occurrence of estrous and the formation of corpora lutea in beef heifers (248). These actions appear to be centrally mediated, since GnRH administration stimulated LH secretion in 2DGtreated animals and controls to a similar extent (189). Collectively these studies lead to the idea that neurons controlling pulsatile release of LH may be sensitive to the availability of oxidizable metabolic fuels (122).

\section{3.d.) Thyroid Hormone}

Thyroid hormones are another class of hormones that meet the requirements for a nutritional signal. Nutrition can profoundly alter the synthesis, secretion, peripheral metabolism, and function of thyroid hormones. Weight loss and energy restriction reduces serum $T_{4}$ and $T_{3}$ in several species $(160 ; 252-255)$. Conversely, during dynamic weight gain serum $T_{4}$ and $T_{3}$ increases $(253 ; 256)$. There is apparently a change in hypothalamic and/or pituitary responsiveness to feedback inhibition from circulating thyroid hormones during undernutrition since TSH levels remain the same or even drop during starvation (257), and there is a blunted TSH response to TRH (258). Changes in $\mathrm{T}_{3}$ seen with changes in nutrition seem to involve practically every level of thyroid regulation, beginning in the CNS and ending with the final action of thyroid hormones in the nucleus of cells. The level and composition of energy intake, including whether the organism is in normal energy balance, are important signals directing these hormones 
(259). Thyroid hormones are lipophylic and can diffuse through the blood brain barrier, and feedback to control the release of TRH into portal blood.

In some seasonal breeders, the thyroid gland plays an important role in reproductive transitions. For example, thyroidectomy before the breeding season blocks the eventual transition out of the breeding season in European starlings $(260 ; 261)$. This phenomenon has subsequently been observed in other avian species (262) and in sheep (263). Although thyroid hormones do not seem to affect the onset of the breeding season, estrous cycles can be sustained throughout the spring-summer anestrous period in ovaryintact thyroidectomized ewes housed in a fixed photoperiod (263) and the duration of the breeding season can be lengthened by inhibiting $\mathrm{T}_{4}$ synthesis (264). In the ovariectomized estradiol-treated ewe, pulsatile release of LH (265) and GnRH (266) is maintained at high levels throughout the nonbreeding season if animals have been thyroidectomized during the preceding breeding season. Thus, the steroid-dependent decline in LH pulse frequency that occurs as daylengths increase depends on the presence of thyroid hormones, and thyroidectomy around the time of maximal LH pulse frequency prevents this decline (62). $T_{4}$ appears to be essential for the increased response to estradiol negative feedback that causes seasonal anestrous (267). There is no variation, however in plasma TSH in ewes during changes between the breeding and non-breeding season (263). The response to thyroidectomy can be reversed by treatment with $\mathrm{T}_{4}$, suggesting that this hormone or one of its metabolites, such as $T_{3}$, mediates the influence of the thyroid on termination of the breeding season $(266 ; 268)$. In addition, constant levels of $T_{4}$ are effective, suggesting that it is a change in responsiveness to $T_{4}$ or $T_{3}$ that allows the onset of anestrous and not changes in $\mathrm{T}_{4}$ or $\mathrm{T}_{3}$ per se. Results from 
experiments in which $T_{4}$ was infused into the lateral cerebral ventricles of thyroidectomized ewes and the aforementioned effect of $\mathrm{T}_{4}$ on $\mathrm{GnRH}$ release strongly suggest that they act centrally. However, acute peripheral $\mathrm{T}_{4}$ administration does not alter GnRH secretion in thyroidectomized ewes (269). Anderson et al. (270) tested the response to $T_{4}$ of specific areas within the hypothalamus by inserting $T_{4}$ containing microimplants into various hypothalamic areas. When $T_{4}$ was administered to the premammilary region (PMR), and in some animals to the ventromedial preoptic area (vmPOA), thyroidectomized animals expressed a normal decline in LH at the end of the breeding season. Collectively, these data indicate that the actions of thyroid hormones within specific areas of the hypothalamus are necessary for the transition into seasonal anestrous brought about by increased sensitivity of GnRH release to estradiol negative feedback.

\section{3.e.) Glucocorticoids}

There is a strong negative correlation between corticosteroid secretion and nutritional status in humans, rats, and other mammalian species, suggesting that activity of the hypothalamo-pituitary-adrenal (HPA) axis is important for regulating calorie input, disposition, and mobilization (271). The fact that changes in corticosterone levels reflect nutritional status, along with its influence on central food intake and reproduction make glucocorticoids an interesting and compelling nutritional signal controlling reproduction.

The reproductive axis is inhibited at all levels by various components of the HPA axis (272). In particular, glucocorticoids secreted from the adrenal glands inhibit GnRH release, pituitary gonadotrophs, and the gonads. In pursuing the argument that glucocorticoids are paramount in mediating the inhibitory effects of stress on 
reproduction, studies have shown that administration of natural or synthetic glucocorticoids can inhibit the secretion of the gonadotropins in sheep (273), pigs (274;275), cattle (276), rhesus monkeys (277), and humans (278). However, it should be noted that other studies have failed to observe an effect of glucocorticoids on LH secretion. Treatment of ovariectomized ewes with dexamethasone for 14 days did not decrease the secretion of LH or inhibit the LH response to GnRH; neither did cortisol nor dexamethasone treatment affect the generation of the LH surge in intact ewes (279). In intact rams, an infusion of cortisol for 9 hours did not affect the LH response to GnRH (280). These differences in LH response to glucocorticoids as compared to those of Juniewicz et al. (273) may be due to the short treatment period in Fuquay et al. (280) or sex differences in the case of Phillips et al. (279).

The influence of cortisol on LH secretion may depend upon steroid millieu. Daley et al. (281) reported no change in LH following cortisol administration in castrated rams. However, infusion of castrated rams with a combination of cortisol and estradiol decreased the frequency of LH pulses in these animals more so than estradiol alone. Infusion of estradiol into castrated rams also increased tissue concentrations of GnRH receptor and GnRH receptor mRNA, and cortisol infusion reduced these responses $(281 ; 282)$. These authors speculated that cortisol affects GnRH release by altering its response to estradiol.

The ability of glucocorticoids to affect reproduction also appears to depend upon the duration and route of administration. Application for 7-16 days of acute stressors that activate the HPA axis did not impair reproduction in the pig (283). Consistent with this finding, repeated i.v. injection of cortisol for eight days had no effect on LH secretion in 
ovariectomized pigs, even in the presence of estradiol (274). A subsequent study showed that a similar cortisol treatment paradigm did not influence generation of the LH surge, estrous behavior, or ovulation in gilts (275). In contrast, sustained high cortisol concentrations achieved through intramuscular injections of cortisol twice daily for eight days impaired the secretion of LH in ovariectomized pigs in the absence, but not the presence, of estradiol but only on the eighth day of treatment (274). In intact pigs, sustained elevations of cortisol also impaired estrus expression, generation of the $\mathrm{LH}$ surge, and ovulation (275). Similarly, monkeys (277) and humans (284) require high doses of cortisol for extended periods of time to impair reproduction. The site of glucocorticoid action on the reproductive axis appears to lie centrally. In intact rams, neither cortisol nor dexamethasone had an affect on either basal or GnRH-stimulated LH $(273 ; 280)$. These results support the concept that corticosteroids do not directly affect secretion of LH by the pituitary, but act at the level of the hypothalamus.

In summary, increased secretion of glucocorticoids is not always associated with decreased secretion of the gonadotropins, particularly in cases of acute stress. Furthermore, there may be species differences in the extent to which glucocorticoids inhibit the secretion of LH. Finally, sex and sex steroid status may influence the effects that glucocorticoids have on GnRH and gonadotropin secretion (285).

\section{3.f.) Leptin}

The ob/ob mouse has a homozygous mutation in the obese gene and is hyperphagic, hyperinsulinemic, hyperglycemic, infertile, exhibits abnormally low energy expenditure, and is morbidly obese (286;287). Based on classic parabiosis studies, Coleman et.al. (288) suggested that $o b / o b$ mice lack a blood-borne factor that could 
regulate adiposity by modulation of appetite and metabolism. This prediction subsequently proved true as that hormone was cloned and sequenced by Zhang et.at. (289) and called leptin, from the greek word leptos, meaning thin. Circulating levels of leptin are derived largely from secretion by adipocytes and this hormone plays an important role in regulating body weight and metabolism (290-292). Plasma leptin levels are proportional to body adiposity (293) and leptin potently reduces food intake, body weight and adipose mass when injected into leptin-deficient or normal mice (290-292). Thus, Zhang et al. (289) proposed that leptin acted as an adipostatic hormone whose primary function is to combat obesity. However, leptin levels decrease with fasting (160) and other studies have shown that prevention of the decrease in leptin seen with fasting blunts the activation of the HPA axis and prevents the suppression of the thyroid, reproductive and growth hormone axes $(151 ; 160 ; 294-296)$. Consequently, Frederich et al. (297) proposed that leptin acts as a starvation signal. In truth, leptin undoubtedly serves both purposes, though its more predominant actions probably lie in its function as a signal of reduced energy balance.

A large body of evidence suggests leptin can influence reproduction. Mice overexpressing leptin reach puberty earlier, despite a leaner phenotype (298). On the other hand the $o b / o b$ mouse, which lacks leptin, is infertile. Infertility from this mutation is believed to be due to reduced circulating gonadal steroids (299), likely due to insufficient hypothalamic-pituitary drive (300). Obesity in another genetic model, the $d b / d b$ mouse, results from the absence of a specific isoform of the leptin receptor important for intracellular signaling (301-303). These mice are totally insensitive to the effects of leptin on food intake. Not surprisingly, these mice, like $o b / o b$ mice, are 
hyperphagic, show decreased energy expenditure and morbid obesity, and are infertile (287). A leptin receptor mutation similar to the $d b / d b$ mutation in mice, occurs very rarely in humans (304). These individuals are hyperphagic, morbidly obese, and exhibit abnormal pubertal development (304). Thus, without question, the presence of leptin is required for normal reproductive competency.

Whether leptin acts as a signal for puberty onset, versus being merely permissive, is a matter of some debate. Leptin has been implicated in timing the onset of puberty in rodents (305-307), monkeys (308), and humans (309;310). However, work in the rat has shown that leptin did not advance the age of puberty (307), suggesting that leptin is not the primary trigger initiating puberty in this species. Leptin concentrations also do not change at the time of puberty in rats (311) and increase only after increases in LH at puberty in monkeys (112), indicating that leptin does not have the characteristics to be considered a signal for the onset of puberty. Thus, more work is needed to determine the exact nature of leptin's role in the reproduction of well-nourished individuals. It is clear, however, that leptin can restore reproductive function during undernutrition. Following fasting, monkeys (312), prepubertal heifers (313), and rats (314) being treated with leptin had higher mean LH levels than controls and leptin can restore estrous cycles in fasted mice (160).

The signaling form of the leptin receptor $(\mathrm{ObRb})$ has been found at all points along the HPG axis (315). Distribution of $\mathrm{ObRb}$ in the brain varies among species, but all species studied thus far express ObRb mRNA in the arcuate nucleus and ventromedial nucleus of the hypothalamus (312), two areas acknowledged to be involved in regulating feeding and reproductive behavior. Leptin has been shown to stimulate GnRH secretion 
from hypothalamic explants (316) and reduce fasting-induced decreases in GnRH pulse frequency (314). Yet experiments in the rat (317) and monkey (294) show little coexpression of $\mathrm{ObRb}$ and $\mathrm{GnRH}$ protein or mRNA, suggesting an indirect mechanism of action for leptin-induced GnRH release. An effect of leptin on reproduction also may be due to its influence on metabolic fuel availability. ObRb is located in gluco-sensitive areas of the hypothalamus and brainstem and leptin has been shown to influence these gluco-sensitive neurons, which could then potentially influence GnRH secretion. Leptin may also work via the GH/IGF-1 axis to mediate GnRH release, as the fasting-induced decrease in GH secretion was prevented by leptin treatment in rats $(296 ; 318)$. Leptin restored both LH and GH secretion in castrate male sheep that had been fasted for $78 \mathrm{hr}$ (319).

Leptin may also have a direct effect on pituitary release of LH. ObRb is expressed in the anterior pituitary and leptin stimulates gonadotropin release from rat anterior pituitary fragments in vitro (316). Maciel et al. (313) have shown leptin to increase the pituitary's responsiveness to GnRH. In the gonads, leptin has been shown to regulate mRNA expression for side chain cleavage enzyme and 17- $\alpha$-hydroxylase (315), enzymes involved in steroid synthesis, and to modulate LH-stimulated estradiol production by the ovary (320). Leptin receptors are also present in rodent leydig cells and leptin has been reported to inhibit basal and stimulated testosterone production in vitro (321). Leptin levels are negatively correlated with basal and stimulated testosterone levels in humans (322). Leptin may also affect reproduction via the HPA axis. Leptin treatment of wildtype mice prevents fasting-induced increases in corticosterone and suppression of estrous cycles (160). 
In summary, leptin is an adipocyte-derived hormone that is critical for both normal body weight regulation and reproductive development. Whether leptin plays an active role in puberty onset or is simply permissive remains to be determined. What seems to be clear is that leptin drops precipitously with undernutrition and leptin replacement restores reproductive function. Thus leptin may be an important "metabolic" hormone linking nutrition with reproduction.

\section{4) Central Integration of Reproductive and Nutritional Cues}

\section{4.a.) Hypothalamus}

Special subsets of neurons within the hypothalamus are sensitive to circulating nutrients that reach them. There are glucosensitive neurons in the VMH and lateral hypothalamus and some neurons in these areas are responsive to not only glucose but amino acids and fatty acids as well (323). Some hormones, notably leptin and insulin, are actively transported into the brain and receptors for both leptin and insulin are expressed in areas of the hypothalamus important for regulating food intake. Other hormones, such as glucocorticoids, may modulate the responses to these signals. Food deprivation decreases the number of estradiol responsive immunoreactive cells in the VMH and increases numbers of these cells in the Arc and POA (324). The hypothalamus also receives neural input from several areas, notably the nucleus tractus solitarius and area postrema in the brainstem, that relay many neural and hormonal signals from the periphery and/or gastrointestinal tract (325). To influence reproduction, nutritional signals must be transduced into neural inputs that then influence GnRH neuronal activity. Although there are many likely candidates, NPY is a particularly attractive one. 


\section{4.a.1. NPY and Food Intake}

Neuropeptide Y (NPY), a 36 amino acid member of the pancreatic polypeptide family, was first isolated in $1982(326 ; 327)$. In the brain, NPY is expressed at high levels in the arcuate nucleus of the hypothalamus, nucleus accumbens, septum, and the periaqueductal gray matter, as well as in lesser amounts in the hippocampus, amygdala, thalamus and basal ganglia (328). Most of its metabolic effects, however, arise from cells located within the hypothalamus (329).

NPY is one of the most powerful known endogenous stimulators of food intake. NPY neurons found in the Arc that project to the PVN (paraventricular nucleus) are responsible for the stimulatory effects of NPY on feeding behavior $(330 ; 331)$. This member of the pancreatic polypeptide family interacts with at least six distinct G proteincoupled receptors designated $\mathrm{Y}_{1}, \mathrm{Y}_{2}, \mathrm{Y}_{3}, \mathrm{Y}_{4}, \mathrm{Y}_{5}$, and $\mathrm{y}_{6}(332)$. The $\mathrm{Y}_{1}$ receptor has a high affinity for NPY and its mRNA and receptor protein is abundantly expressed in many rat and mouse brain regions, including hypothalamic centers controlling energy homeostasis (333-335). Receptor $Y_{5}$ has also been implicated in mediating NPY's effects on food intake, with receptor mRNA discreetly localized in the arcuate nucleus and PVN of the rat and mouse brain (334-336). Intracerebroventricular administration of NPY stimulates food intake, presumably via the $\mathrm{Y}_{5}$ receptor and at least some of the other NPY receptor subtypes in the hypothalamus $(337 ; 338)$.

Acutely, NPY stimulates food intake, even in satiated animals, for hours following central administration (339-342). When administered chronically, NPY induces a state mimicking hormonal and metabolic changes seen in obesity (343). Indeed, repeated (344) and continuous (345) administration of NPY into hypothalamic 
sites produces obesity. NPY provides such a strong motivation to eat that NPY-treated animals will carry out operant behaviors such as lever pressing and will endure electric shocks in order to obtain food (346). Both secretion and content of NPY in the PVN increases in rats with a robust drive for feeding following fasting (331). NPY returns to control levels upon initiation of feeding (347) and its release is closely associated with the energy requirements of the rats (331). Studies of ovariectomized sheep living outdoors indicate that changes in the expression of NPY mRNA and NPY peptide levels in the arcuate correlate with seasonal changes in voluntary food intake $(64 ; 348)$.

\section{4.a.2.) NPY and Reproduction}

NPY influences GnRH release and potientates the responsiveness of gonadotrophs to GnRH (349). NPY may also be involved in mediating steroid negative feedback on GnRH release. NPY alters GnRH and LH release $(67 ; 146-148)$ and NPYcontaining neurons synapse directly onto GnRH neurons (149). Although GnRH neurons themselves have not been shown to contain ER $\alpha$ or androgen receptors, NPY neurons do coexpress ER $\alpha$ (150). Thus, steroid-induced changes in GnRH and LH release may, at least in part, be due to altered input from the NPY system.

Whether NPY stimulates or inhibits GnRH/LH secretion depends somewhat on the context in which it is examined. Much of the work has been done in females and a large body of evidence suggests that NPY is stimulatory to GnRH release during the follicular phase/preovulatory LH surge. In the rat, NPY mRNA and protein levels increase at the time of the preovulatory LH surge (350-353) and reducing NPY input can attenuate or block the LH surge $(349 ; 354)$. Data are more limited in other species, but generally support a stimulatory role for NPY in generation of the GnRH surge for sheep 
(355-357), monkeys (358;359), and mice (360). In contrast, the influence of NPY on tonic LH release varies and depends upon the particular species examined. In rats, the role of NPY appears to depend upon the prevailing steroidal environment. NPY inhibits $\mathrm{GnRH} / \mathrm{LH}$ release in ovariectomized rats but stimulates $\mathrm{GnRH} / \mathrm{LH}$ release in steroidtreated animals (360-364). In monkeys, perfusion of the median eminence with NPY stimulates GnRH release in males and females regardless of the presence or absence of steroids $(148 ; 365)$. In domestic livestock species, the influence of NPY on tonic GnRH/LH secretion seems to be uniformly inhibitory. NPY inhibits LH secretion in ewes or cows that are ovariectomized or ovariectomized and implanted with estradiol $(17 ; 67 ; 115 ; 147 ; 366)$.

NPY-containing neurons synapse directly onto GnRH neurons (149). One site of action of NPY resides in the mPOA where synaptic links between immunopositive NPY axon terminals and soma containing GnRH have been observed (367). The NPY network also communicates directly or indirectly through other efferents with the GnRH network in the ME-Arcuate as NPY readily stimulates GnRH release from nerve terminals in the ME (361). Thus experimental evidence to date is consistent with the view that the NPY network in the arcuate nucleus/median eminence and the mPOA represents an integral link in the neural circuitry regulating GnRH secretion.

\section{4.a.3.) Seasonal Changes in NPY}

Relatively few studies have examined NPY in a seasonal context, but these studies suggest that NPY gene and protein levels change in a season-dependent manner. Hypothalamic NPY-containing cell numbers and NPY mRNA expression is higher during the breeding season in ovariectomized ewes, and estradiol did not influence this 
response $(348 ; 368)$. Skinner and Herbison (369) observed that numbers of immunoreactive NPY neurons are increased during the mid-luteal phase of the estrous cycle compared to anestrous. Clarke et al. (370) observed that NPY mRNA levels increased during a long-day photoperiod in intact male sheep. While these studies clearly suggest that hypothalamic NPY levels change with daylength, it is not possible to determine the exact stimulus for these changes. It may be that NPY input can be altered directly by changes in photoperiod. Also, differences in NPY levels could potentially be explained by differences in the steroid milieu that prevails during the mid-luteal phase of the estrous cycle (e.g. progesterone) compared to anestrous (e.g. estradiol). Alternatively, since NPY is an important regulator of food intake and metabolism, changes in ambient temperature or other environmental factors could affect expression. Therefore, one aspect of my thesis investigates the relationship between NPY mRNA expression and LH secretion during different photoperiods and steroid environments in male sheep.

\section{4.a.3.) Sex-differences}

Sex-related differences exist in response to various energy states and hypothalamic neuropeptides known to be involved in controlling food intake, and potentially linking nutritional changes to reproductive changes. Interestingly, female NPY knock-out mice respond more robustly than male NPY knock-out mice to leptin (371;371) and NPY appears to be responsible for a greater percentage of obesity in females than males when NPY knock-out mice are crossed onto an $o b / o b$ background (371). In $o b / o b$ mice lacking NPY, one third of the females were fertile compared to only $5 \%$ of the males (371). Since $o b / o b$ mice are always infertile, this finding suggests that 
NPY may play a role in leptin deficient infertility to a greater degree in females than males. NPY-Y2 receptor knock-out mice of both sexes show a decrease in body weight relative to controls, yet food intake is decreased in males and increased in females (372). NPY-Y1 receptor deletion caused a fourfold increase in fat mass as a percentage of body weight in females, but no increase in males.

\section{4.b.) brainstem}

In addition to the hypothalamus, the brainstem may play an important role in linking nutrition and reproduction. The area postrema (AP) and nucleus of the solitary tract (NTS), both within the brainstem, transmit metabolic information to hypothalamic areas that influence GnRH release. The AP is ideal for sensing peripheral metabolic information because it lacks a distinct blood-brain-barrier (373). Ritter et al. (374) have defined more specific sites within the hindbrain that are glucosensitive. These areas in the dorsomedial region are intimately associated with the fourth ventricle, in close proximity to the $\mathrm{AP}$, and the ventrolateral sites are close to an area on the ventrolateral surface of the medulla that has been shown to have a higher local glucose utilization rate, higher blood flow, and a greater density of perfused capillaries than surrounding medullary tissue (375). These are areas very well suited for sensing peripheral glucose concentrations and neuronal cell bodies in the AP-NTS project to the rostral structures of the brain, including the PVN and lateral hypothalamus, which are implicated in the regulation of feeding and reproduction (376). Therefore it is likley that peripheral metabolic signals are detected here and the information is relayed to rostral structures controlling both GnRH secretion and food intake. Indeed, neural elements of the AP are necessary for glutamate-induced feeding (377). 
Caudal brainstem structures have been suggested to mediate the suppressive effect of glucoprivation induced by $2 \mathrm{DG}$ on pulsatile $\mathrm{LH}$ secretion in the rat. Infusion of very low doses of 2DG into the fourth ventricle will suppress LH secretion in the rat (373). The AP mediates the suppression of pulsatile LH secretion in response to insulin-induced hypoglycemia (378). AP lesions block metabolic inhibitor-induced suppression of estrous behavior as well as the associated decrease in ER immunoreactivity in the VMH (324). These authors suggested that estrogen-binding cells in the VMH, critical for induction of lordosis in hamsters, receive information about metabolic fuel availability via the AP. Similarly, AP lesions block 2DG-induced inhibition of estrous cycles in Syrian hamsters (379). Specifically lesioning catecholaminergic neurons that project from the brainstem to the PVN eliminate the increased length of estrous cycles seen during glucoprivation (380) Thus the brainstem seems to play an essential role during limited glucose availability with regard to inhibiting estrous behavior and expression of estrous cycles, at least in rodent models studied thus far.

Table 1

Effect of neurotransmitters that mediate steroid negative feedback on GnRH/LH secretion

\begin{tabular}{|l|c|l|}
\hline$\beta$-endorphin & inhibitory & Barb et al. (381) \\
\hline Norephinphrine $^{* *}$ & inhibitory & $\begin{array}{l}\text { Havern et al. (382), Riggs } \\
\text { and Malven (383) }\end{array}$ \\
\hline Dopamine* & inhibitory & $\begin{array}{l}\text { Lehman et al. (384), Havern } \\
\text { et al. (382) }\end{array}$ \\
\hline NPY & $\begin{array}{c}\text { inhibitoryl } \\
\text { stimulatory }\end{array}$ & $\begin{array}{l}\text { Bauer-Dantoin et al. (146), } \\
\text { Woller et al. (148), Barker- } \\
\text { Gibb et al. (67), Malven et } \\
\text { al. (147) }\end{array}$ \\
\hline$\gamma$-aminobutyric acid & inhibitory & Ferreira et al. (385;386) \\
\hline glutamate & stimulatory & Caraty et al. (387) \\
\hline
\end{tabular}

* May only have effect during anestrous

** NE is necessary for the LH surge to occur

\# Dependent on species 


\section{Chapter 2}

\section{NEUROPEPTIDE Y GENE EXPRESSION IN MALE SHEEP: INFLUENCE OF PHOTOPERIOD AND TESTOSTERONE}

\section{$\underline{\text { Abstract }}$}

The frequency of pulsatile release of gonadotropin-releasing hormone $(\mathrm{GnRH})$ and LH is high in the breeding season and low in the nonbreeding season. These alterations in the patterns of $\mathrm{GnRH}$ and $\mathrm{LH}$ release are due to an interaction of daylength and gonadal steroid negative feedback. A vast amount of data indicates that steroid-responsive neural systems play a role in regulating seasonal changes in GnRH release. One candidate system is neuropeptide Y (NPY). To determine the independent and interactive influences of photoperiod and steroid exposure on NPY mRNA levels, we used hypothalamic tissue from four groups ( $\mathrm{n}=4$ per group) of castrated male sheep that were simultaneously housed in photochambers and exposed to: 1) a 16L:8D photoperiod (LD), 2) LD and implanted with testosterone (LD+T), 3) a 10L:14D photoperiod (SD), and 4) $\mathrm{SD}+\mathrm{T}$. Circulating levels of $\mathrm{T}$ averaged $2.8 \pm 0.2 \mathrm{ng} / \mathrm{ml}$ in implanted animals, but were undetectable in nonimplanted males. Mean LH levels were significantly reduced $(\mathrm{P}<0.01)$ in the LD+T group compared to the other groups which did not differ from each other. Silver grain area per NPY neuron in the arcuate nucleus, as assessed by in situ hybridization, was inversely related to mean LH values with grain area per cell being significantly greater $(\mathrm{P}<0.05)$ for $\mathrm{LD}+\mathrm{T}$ males than all other groups, which did not differ from each other. NPY cell numbers were not significantly different $(\mathrm{P}>0.10)$ among treatment groups. These results show that NPY expression is increased in male sheep 
during a LD photoperiod in a T-dependent manner. Our data are consistent with the idea that NPY is involved in seasonal regulation of GnRH and LH release in the male sheep.

\section{$\underline{\text { Introduction }}$}

Sheep are seasonal breeders that exhibit reproductive activity during the relatively shorter days of fall and early winter and transition into reproductive quiescence during the lengthening days of late winter or early spring $(388 ; 388)$. These seasonal swings in reproductive activity are due to changes in pulsatile patterns of gonadotropin hormone releasing-hormone $(\mathrm{GnRH})$, and thus, luteinizing hormone $(\mathrm{LH})$ secretion. During the breeding season, pulsatile GnRH and LH secretion exhibits a high frequency pattern of release whereas during the nonbreeding season, $\mathrm{GnRH}$ and $\mathrm{LH}$ secretion is characterized by a low-frequency pattern of release. These alterations in the patterns of GnRH and LH release are due to an interaction of daylength and gonadal steroid negative feedback (389393). However, the neural mechanisms whereby steroids and photoperiod interact to control GnRH and LH secretion are not completely understood.

Whether steroids directly influence GnRH release by acting directly at GnRH neurons has been a matter of much study. The fact that GnRH neurons apparently contain few, if any, estrogen receptor (ER)- $\alpha$ or androgen receptors $(394 ; 395)$ has led to the idea that gonadal steroids do not act directly to influence GnRH release. However, it has recently been reported that GnRH neurons coexpress mRNA and protein for ER- $\beta$ (396-399), another ER isoform. This raises the possibility that estradiol may directly influence GnRH neural cell function, although the nature of that effect has not been clearly established in vivo. Clearly, however, steroids influence GnRH release through other steroid-responsive neurons. Neuropeptide Y (NPY), a 36 amino acid peptide 
synthesized and prevalent in the arcuate nucleus (400-402), is one candidate. NPY alters GnRH and LH pulsatility (403-406) and NPY-containing neurons synapse directly onto GnRH neurons (407). In addition, NPY neurons coexpress ER $\alpha$ (408). Thus, photoperiod-induced changes in GnRH and LH release may, at least in part, be due to altered input from a steroid-responsive NPY system.

The relatively few studies that have examined NPY in a seasonal context suggest that NPY mRNA and protein levels change in a season-dependent manner. Clarke et al. (409) observed that NPY mRNA levels increased during a long-day photoperiod in intact male sheep. In female sheep, hypothalamic NPY-containing cell numbers and NPY mRNA expression was higher during the breeding season in ovariectomized ewes, and estradiol did not influence this response (410). Skinner and Herbison (411) observed that numbers of immunoreactive NPY neurons in ewes are increased during the mid-luteal phase of the estrous cycle compared to the nonbreeding season. While these studies clearly suggest that hypothalamic NPY levels change with daylength, it is not possible to determine if these changes are due solely to photoperiod or if they may also be influenced by ambient temperature or steroid environment. In order to determine the independent and interactive influences of photoperiod and steroid exposure on NPY mRNA levels, we used hypothalamic tissue from males that were contemporaneously exposed to either long or short daylengths in the presence or absence of testosterone.

\section{Materials and Methods}

Tissues used in this study were taken from animals used in a previously published report (412). Twenty black-faced sheep, predominantly of the Suffolk breed, were 
housed at the Veterinary Research Farm at the University of Illinois, Urbana (Latitude $40^{\circ} \mathrm{N}$ ) and maintained in light-sealed photochambers that were partially controlled for temperature by air conditioners and heating units. They were fed alfalfa hay and allowed water ad libitum. All procedures were carried out in accordance with NIH Guidelines for the Care and Use of Laboratory Animal Care.

Eight males were long-term castrates ( $>6$ months) while 12 were castrated 1 month prior to the beginning of the experiment. Animals were assigned to one of four treatment groups with assignment balanced for time postcastration: 1) short day (8L:16D), no testosterone (SD), 2) short day with testosterone (SD+T), 3) long day (16L:8D), no testosterone (LD), and 4) long day with testosterone (LD+T). The LD groups entered photochambers on September 21 and were subjected to 90 days of 16L:8D followed by 90 days of $8 \mathrm{~L}: 16 \mathrm{D}$ and then a final 90 days of $16 \mathrm{~L}: 8 \mathrm{D}$. The SD groups were left outdoors until December 21 whereafter they were subjected to 90 days of $16 \mathrm{~L}: 8 \mathrm{D}$ followed by a final 90 days of $8 \mathrm{~L}: 16 \mathrm{D}$. LD and LD+T animals were put through successive photoperiod treatments to phase reverse the change in LH secretion so that all animals could be sacrificed at a similar time and ambient temperature, but under contrasting photoregimens.

Animals receiving testosterone were implanted as previously described (413) on December 21. To validate the LH response to photoperiod and determine circulating testosterone levels, blood samples were collected twice weekly via jugular venipuncture during the last 3 weeks of the final photoperiod treatment and assayed for plasma $\mathrm{T}$ and LH as previously described (414). At the end of the study, animals were euthanized with an overdose of barbiturate and hypothalami were quickly excised. Tissue was frozen 
quickly on dry ice and stored at $-70^{\circ} \mathrm{C}$ until sectioned on a cryostat and used for in situ hybridization.

\section{$\underline{\text { In situ hybridization }}$}

Radiolabeled cRNA probes for ovine NPY mRNA were generated from a $311 \mathrm{bp}$ cDNA sequence kindly provided by Dr. Duane Keisler (University of Missouri, Columbia MO). Probes were labeled with ${ }^{35} \mathrm{~S}-\mathrm{UTP}$ and tissue sections were processed as previously described (23-24). Tissue sections through the arcuate nucleus were hybridized under glass cover slips overnight at $55^{\circ} \mathrm{C}$ with labeled cRNA $\left(5 \times 10^{5} \mathrm{cpm} / 40\right.$ $\mu l$ hybridization buffer/section). Post-hybridization washes were performed as described by Greco et al. (415). Tissue sections then were dipped in autoradiographic emulsion (NTB3; Kodak, Rochester NY) diluted 1:1 with deionized $\mathrm{H}_{2} \mathrm{O}$. Sections were exposed for approximately 10 days at $4^{\circ} \mathrm{C}$, and then developed with Dektol developer and Kodak Fixer. Finally, tissue sections were counterstained with $0.08 \%$ Toluidine-O Blue and coverslipped with Depex. Hybridization controls on test tissues included hybridization with labeled 'sense' strand cRNA probes. No hybridization signal was detected on these tissues.

Sections of the arcuate nucleus from each animal were anatomically matched according to the arcuate shape and relation to the third ventricle, and a researcher unaware of the treatment groups analyzed two of these sections. Due to the large number of NPY containing cells, only one side of each section was analyzed. Results obtained were an average of these two hemi-sections. Silver grain area above individual neurons was determined at $40 \mathrm{X}$ using the public domain program NIH Image (developed at the US National Institutes of Health and available on the Internet at 
http://rsb.info.nih.gov/hin-image/). Light intensity and threshold were set and maintained for all animals. For each animal, silver grains above individual neurons were digitized on screen and the area occupied by the grains minus the background was determined.

\section{$\underline{\text { Statistical analysis }}$}

NPY silver grain area per neuron and cell number were calculated for each animal and then averaged among animals to derive treatment group means. Values were compared using a two-way analysis of variance with the model including steroid, photoperiod and the steroid $\mathrm{x}$ photoperiod interaction. Comparisons between individual treatment groups were performed by the test of Least Significant Difference.

\section{$\underline{\text { Results }}$}

\section{LH and Testosterone}

As previously reported (416), $\mathrm{LH}$ values were significantly lower $(\mathrm{P}<0.01)$ in the $\mathrm{LD}+\mathrm{T}$ group (all below assay sensitivity of $2.0 \mathrm{ng} / \mathrm{ml}$ ) compared with all other treatment groups. LH values did not differ $(\mathrm{P}>0.10)$ among SD $(14.94 \pm 1.16 \mathrm{ng} / \mathrm{ml}), \mathrm{SD}+\mathrm{T}(15.32 \pm 0.66$ $\mathrm{ng} / \mathrm{ml})$ and LD $(16.49 \pm 1.16 \mathrm{ng} / \mathrm{ml})$ groups. Circulating testosterone concentrations in testosterone-implanted males were $2.75 \pm 0.16 \mathrm{ng} / \mathrm{ml}$. Testosterone levels were below assay sensitivity $(1.0 \mathrm{ng} / \mathrm{ml})$ in males without $\mathrm{T}$ implants.

\section{NPY mRNA Expression and Cell Numbers}

Photomicrographs from individual animals representing each treatment group are shown in Figure 1. Group means for silver grain area per neuron and cell numbers are shown in Figures 2 and 3, respectively. Silver grain area per NPY neuron was inversely related to mean $\mathrm{LH}$ values with grain area being significantly greater $(\mathrm{P}<0.05)$ for $\mathrm{LD}+\mathrm{T}$ animals 
than all other groups. Grain area did not differ significantly ( $\mathrm{P}>0.10)$ among LD, SD, and SD+T. NPY cell numbers did not differ among groups $(\mathrm{P}>0.40)$.

\section{$\underline{\text { Discussion }}$}

Our study is the first to examine the independent influences of photoperiod and testosterone on NPY gene expression in the arcuate nucleus of the sheep. The results suggest that testosterone alters NPY gene expression during a long-day, but not shortday, photoperiod. Interestingly, NPY mRNA levels inversely reflected mean LH values in our study, i.e. LH values were reduced only in the group expressing significantly higher NPY mRNA levels. These data suggest that reductions in LH secretion resulting from photoperiod-induced increases in sensitivity to testosterone negative feedback may be mediated, at least in part, by elevated NPY.

The inverse relationship in our study of mean LH values and NPY mRNA expression suggests that NPY inhibits LH secretion. Whether NPY stimulates or inhibits $\mathrm{GnRH} / \mathrm{LH}$ secretion depends somewhat on the context in which it is examined. Much work has been done in females and a large body of evidence suggests that NPY is stimulatory to GnRH release during the follicular phase/preovulatory LH surge. In the rat, NPY mRNA and protein levels or NPY-Y1 receptor mRNA levels increase at the time of the preovulatory LH surge (417-421) and reducing NPY input can attenuate or block the LH surge $(422 ; 423)$. Data are more limited in other species, but generally support a stimulatory role for NPY in generation of the GnRH surge for sheep (423-425), monkeys (426;427) and mice (428). In contrast, the effect of NPY on tonic LH release varies and depends upon experimental conditions. In rats, the role of NPY appears to depend upon 
the prevailing steroidal environment since NPY inhibits GnRH/LH release in ovariectomized rats but stimulates GnRH/LH release in steroid-treated animals (429433). In monkeys, perfusion of the median eminence with NPY stimulates GnRH release regardless of steroid milieu (434-436). Interestingly, NPY delivered to the third ventricle inhibits GnRH release (437) suggesting that the influence of NPY on GnRH release may be site-specific in this species. Consistent with our data, the influence of NPY on tonic GnRH/LH secretion seems to be uniformly inhibitory in domestic livestock species. NPY inhibits LH secretion in ewes or cows that are ovariectomized or ovariectomized and implanted with estradiol (438-443). This is consistent with the elevation in NPY gene expression normally observed during food restriction in both male (444) and female sheep (445), periods that are characterized by low levels of tonic LH secretion, and agrees with our observation that NPY mRNA levels were inversely related to mean LH levels.

To our knowledge, ours is the first report to examine the effect of testosterone within short and long days on NPY mRNA expression in domestic livestock species. Clarke et al. (446) observed that arcuate NPY mRNA levels increased during long days in intact male sheep. We also observed an increase in NPY gene expression during long days, but only in response to testosterone, suggesting that photoperiod by itself is not a sufficient stimulus. Our data are consistent with previous work showing that testosterone stimulates NPY. In humans, NPY levels decrease with antiandrogen treatment (447) and increase in women with polycystic ovarian syndrome who exhibit increased circulating testosterone levels (448). In rats, castration reduces and testosterone stimulates NPY mRNA and protein levels (449-454). However, our data are at odds with that observed 
for monkeys wherein castration or treatment with testosterone does not affect NPY mRNA levels $(455 ; 456)$, suggesting that species differences exist in the effects of testosterone on NPY input.

There appears to be a significant sexual dichotomy in the regulation of NPY by photoperiod and steroids. As mentioned above, testosterone stimulates NPY gene and protein expression in male rats and we found that NPY mRNA levels increased only in $\mathrm{LD}+\mathrm{T}$ animals. In contrast, work in the ewe (457) shows that seasonal changes in NPY mRNA or protein expression are steroid-independent and actually increase during short days, e.g. the breeding season. Furthermore, NPY levels in female rats were observed to be only half that of male rats (458) and several studies have reported an inhibitory effect of estradiol on NPY mRNA or peptide levels in female rats (459-462). Thus, it may be that NPY mRNA and protein levels are suppressed in the estradiol-dominated female while they are stimulated in the androgen-dominated male. Sexually dimorphic NPY levels may, at least in part, be due to the metabolism of testosterone to dihydrotestosterone (DHT) via the enzyme $5 \alpha$-reductase in males. We previously showed that conversion of testosterone to DHT is an important step in inhibition of LH secretion by testosterone (463). While the influence of DHT on NPY has not been directly assessed, like testosterone, DHT prevents cold-induced loss of body weight (464), increases body mass (465), and increases food intake (466;467) raising the possibility that DHT may mediate, at least in part, metabolic responses involving NPY that are influenced by testosterone.

Although our data are consistent with the idea that daylength-induced alterations in NPY input may play a role in regulating seasonal fluctuations in tonic LH secretion 
and fertility, they are also consistent with the notion that changes in NPY input underlie seasonal alterations in voluntary food intake. Castration reduces and testosterone stimulates body weight gain, nitrogen retention, and/or food intake in a number of species (468-478). Intact male sheep exhibit increased numbers of cells expressing NPY and increased NPY mRNA during long days that are associated with increased voluntary food intake (479). Furthermore, NPY is a well known, potent stimulator of food intake in several species including sheep (480). Thus, an increase in NPY mRNA expression in response to testosterone during long days may play a role in increasing voluntary food intake in male sheep.

Most likely, however, is that NPY is involved in regulating both reproduction and food intake. Nutrition and reproduction are heavily intertwined and NPY may be one neuropeptide system linking one with the other. In male sheep, photoperiod alters androgenic input to $\mathrm{GnRH}$ neurons so that the ability of testosterone to suppress reproduction is maximal during long days. Based on our data, we would suggest that NPY may be part of this inhibitory pathway, while fulfilling a dual role by stimulating voluntary food intake during this time of year when food availability is greatest. 

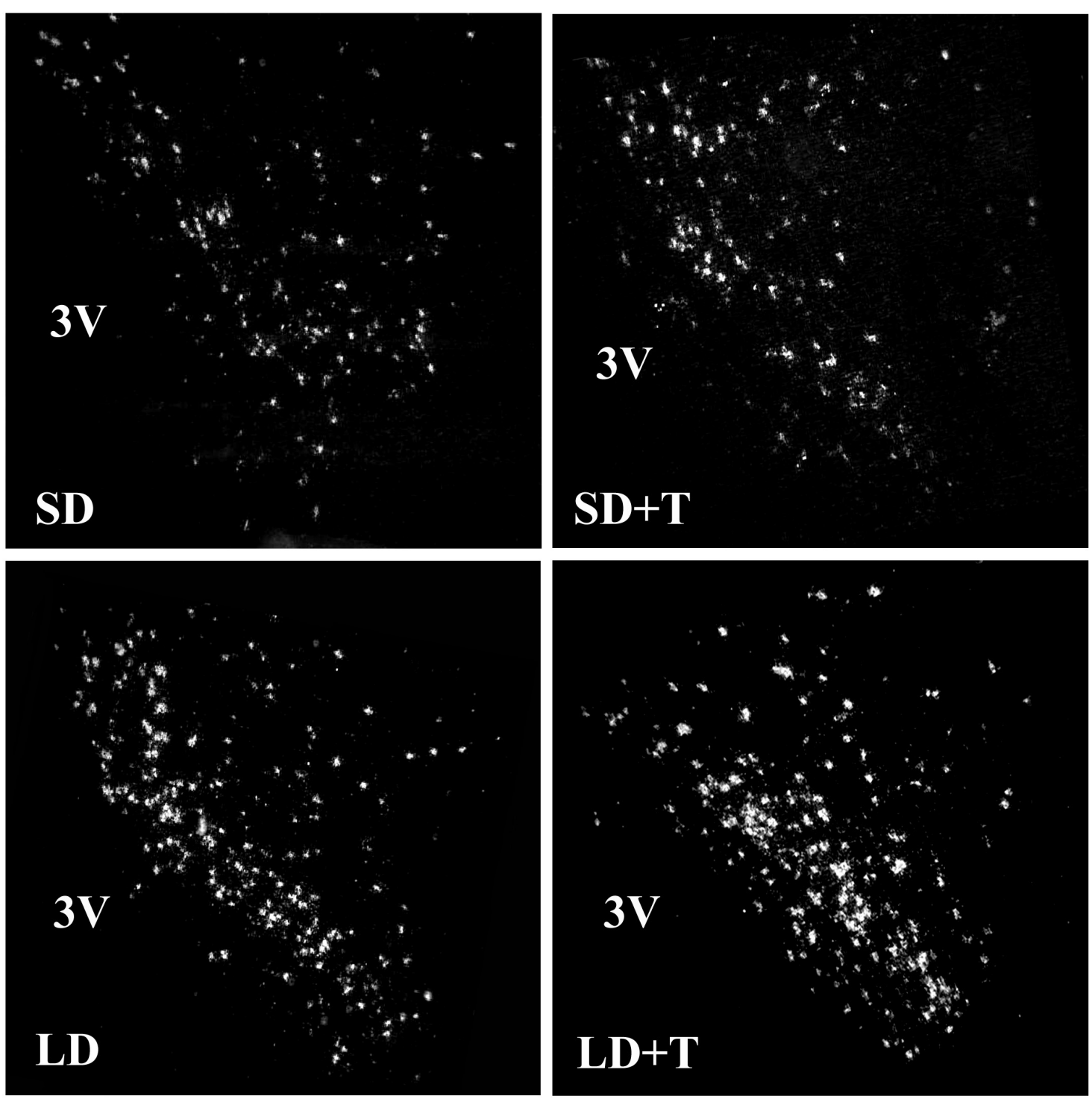

Figure 1 


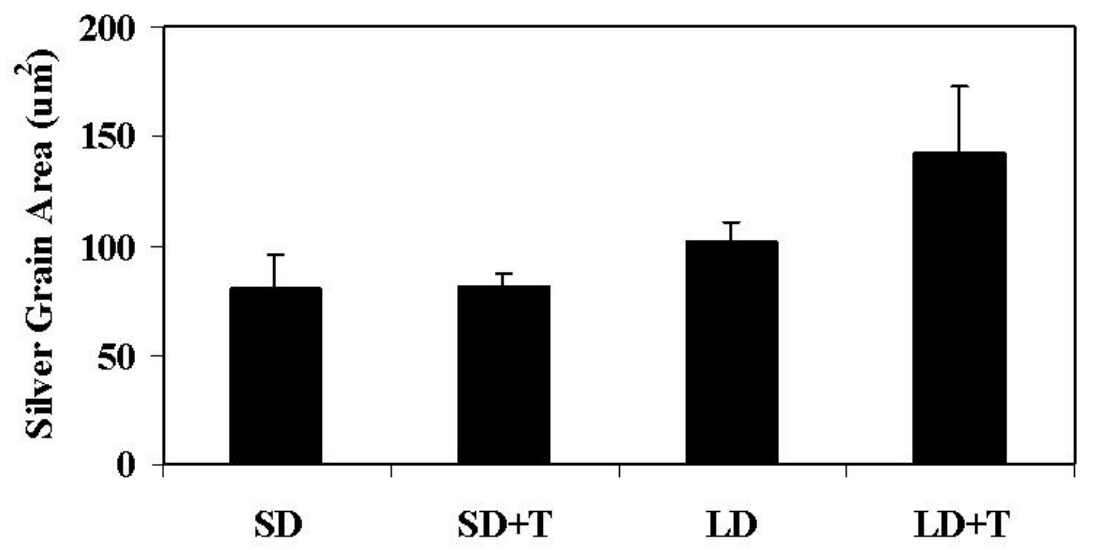

Figure 2

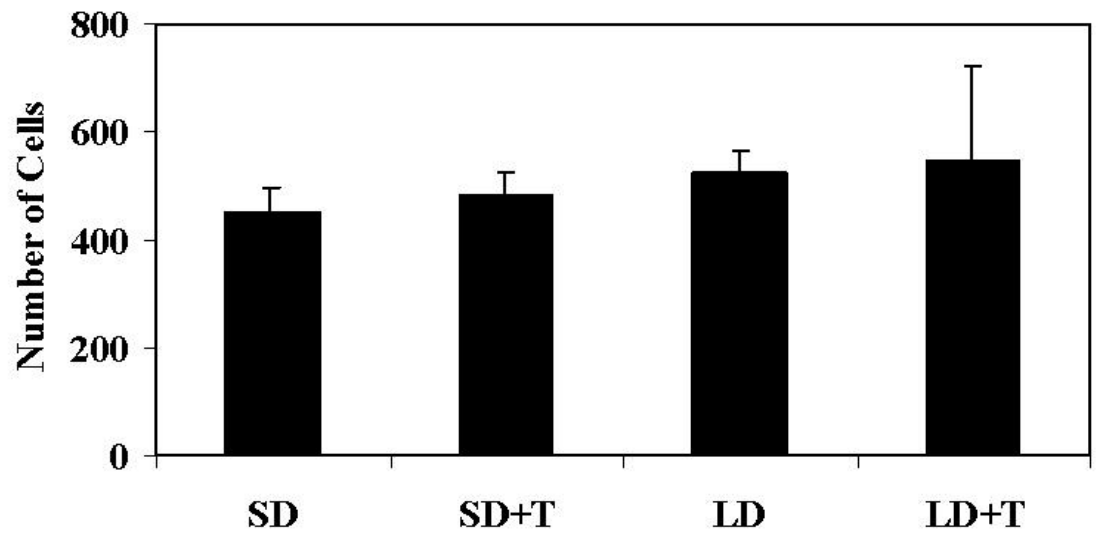

Figure 3 


\section{Figure Legends}

Figure 1. Darkfield photomicrographs (10X) of the arcuate nucleus of the hypothalamus taken from representative animals for SD, SD+T, LD, and LD+T. Sections were exposed to a cRNA antisense NPY probe corresponding to nucleotides ------ of the ovine NPY sequence. $3 \mathrm{~V}$ - third ventricle.

Figure 2. NPY mRNA expression as assessed by silver grain area per neuron $\left(\mu \mathrm{M}^{2}\right)$ for $\mathrm{SD}, \mathrm{SD}+\mathrm{T}, \mathrm{LD}$, and $\mathrm{LD}+\mathrm{T}$ animals. NPY silver grain area was elevated $(\mathrm{P}<0.05)$ only in LD+T animals, and SD, SD+T, and LD groups did not differ significantly $(\mathrm{P}>0.10)$. One side of each of two arcuate sections were assessed per animal and values represent the mean \pm SEM of 4 animals per group.

Figure 3. Numbers of NPY cells per animal for SD, SD+T, LD, and LD+T animals. Cell numbers did not differ significantly $(\mathrm{P}>0.10)$ among treatment groups. One side of each of two arcuate sections were assessed per animal and values represent the mean \pm SEM of 4 animals per group. 


\title{
Chapter 3
}

\section{INFLUENCE OF INSULIN-LIKE GROWTH FACTOR-1 (IGF-1) ON THYROXINE (T4) AND TRIIODOTHYRONINE (T3) IN FOOD-DEPRIVED MALE AND FEMALE SHEEP}

\begin{abstract}
Three experiments were performed to test the hypothesis that IGF-1 alters circulating levels of total $\mathrm{T}_{4}$ and total $\mathrm{T}_{3}$. For the first two experiments, we used ewes 9 months of age, each of which was ovariectomized and implanted sc with a $1 \mathrm{~cm}$ estradiol implant. In Experiment 1, ewes were food-deprived for 6 days with 3 blood samples collected every $2 \mathrm{~h}$ on Day 0 prior to food removal and on days 2, 4, and 6 of food withdrawal. Beginning on Day 4, ewes received subcutaneous injections of saline (controls; $n=5$ ), or IGF-1 at either $50 \mathrm{ug} / \mathrm{kg} / \mathrm{d}(\mathrm{n}=4)$ or $10 \mathrm{ug} / \mathrm{kg} / \mathrm{d}(\mathrm{n}=5)$ twice daily $(0800$ and $2000 \mathrm{~h})$. For all studies, we used long R3-IGF-1, an analog with reduced affinity for IGF-1 binding proteins. Six days of food deprivation lowered total $\mathrm{T}_{4}$ and total $\mathrm{T}_{3}$ levels in controls. IGF-1 elevated both total $\mathrm{T}_{4}$ and total $\mathrm{T}_{3}$ in a dose-dependent fashion by Day 6 of food withdrawal. In Expt 2, females were food deprived for 6 days and then given intravenous injections of IGF-1 at either $25 \mathrm{ug} / \mathrm{kg}(\mathrm{n}=5), 12.5 \mathrm{ug} / \mathrm{kg}(\mathrm{n}=5)$, or $6.25 \mathrm{ug} / \mathrm{kg}(\mathrm{n}=5)$. Blood samples were collected at 12-min intervals for the subsequent hour and another sample collected at $2 \mathrm{~h}$ postinjection. IGF-1 increased total $\mathrm{T}_{4}$ values significantly in all groups at 60 and 120 min postinjection, but increased total $T_{3}$ in all groups by 36 minutes postinjection. In Experiment 3, castrated males that were 9 months old and implanted
\end{abstract}


with a $1 \mathrm{~cm}$ estradiol implant were food deprived for 4 days. During this period, they received either saline injections (control; $\mathrm{n}=5)$ or IGF-1 at $25(\mathrm{n}=5), 50(\mathrm{n}=5)$ or 100 $(\mathrm{n}=5) \mathrm{ug} / \mathrm{kg} / \mathrm{d}$ given subcutaneously. Food deprivation decreased total $\mathrm{T}_{4}$ and total $\mathrm{T}_{3}$ levels. IGF-1 was able to maintain total $\mathrm{T}_{4}$ and total $\mathrm{T}_{3}$ levels for 2 days, after which total $\mathrm{T}_{4}$ and total $\mathrm{T}_{3}$ concentrations fell to levels that were less than those on Day 0 , but still greater than those observed in controls. In summary, IGF-1 clearly increased circulating levels of both $\mathrm{T}_{4}$ and $\mathrm{T}_{3}$, but was more potent in females than in males.

\section{Introduction}

For most species, food supply is not constant. Instead they are often exposed to periods of energy abundance and scarcity. To maintain homeostasis and a constant supply of nutrients to the brain, these swings in food availability are met by a variety of compensatory changes in endocrine and metabolic parameters (481). One such change occurs in circulating levels of $T_{4}$ and $T_{3}$, which are important for determining basal metabolic rate $(482 ; 483)$. Weight loss and energy restriction reduces serum $T_{4}$ and $T_{3}$ in several species (160;252-255). Conversely, during dynamic weight gain serum $\mathrm{T}_{4}$ and $\mathrm{T}_{3}$ increases $(253 ; 256)$. This response likely represents a compensatory mechanism to slow

or speed, respectively, metabolism in order to help maintain energy balance. The mechanisms that regulate $T_{4}$ and $T_{3}$ levels during periods of altered energy balance are not completely known. One possibility is that they may be influenced by peripheral signals that reflect metabolic status, such as insulin-like growth factor-1 (IGF-1).

IGF-1 is synthesized in many tissues including brain, hypothalamus, pituitary, and liver (185-187). Secretion of IGF-1 from the liver in response to pituitary-derived growth hormone (GH) accounts for the secretion of approximately $75 \%$ of circulating IGF-1 
(484). IGF-1 acts in endocrine, paracrine, and autocrine fashions as an integral component of multiple systems controlling growth, differentiation, and metabolism $(200 ; 201)$. IGF-1 is markedly affected by the nutritional status of an animal, decreasing during periods of negative energy balance $(204 ; 485)$ and increasing during periods of positive energy balance (486). Thus, circulating levels of IGF-1 reflect energy balance.

Reports of the effects of GH, or IGF-1, on the hypothalamo-pituitary-thyroid (HPT) axis are relatively few, and mostly gathered from human patients with somatotropic abberations. GH-deficient adults (487), and children with either GH deficiency (488) or hypopituitaryism (489) demonstrate decreased serum $\mathrm{T}_{4}$ and increased serum $\mathrm{T}_{3}$ levels. (490) have shown that administration of IGF-1 quickly decreases serum TSH and causes a progressive decline in serum free $\mathrm{T}_{4}$ while $\mathrm{T}_{3}$ levels are maintained in GH-resistant patients. Thus, while it is likely that IGF-1 influences thyroid hormone secretion, the site(s) at which IGF-1 may act is unknown. While the aforementioned data suggests an action at the pituitary, affects at the hypothalamus or thyroid gland itself cannot be ruled out. Furthermore, the above studies used individuals fed a normal diet and so the relationship between IGF-1, $\mathrm{T}_{4}$, and $\mathrm{T}_{3}$ during food deprivation has not been examined. One purpose of these studies is to test the hypothesis that IGF-1 stimulates $\mathrm{T}_{4}$ and $\mathrm{T}_{3}$ secretion in food-deprived animals.

Males and females respond differently to changes in energy state. It has been hypothesized that due to gender-specific evolutionary selection pressures, female mammals have evolved a greater capacity to conserve energy than males (152). Accordingly food restriction has been reported to have a greater and more permanent effect on physical growth in males than in females and in mature humans and animals, 
males are more susceptible to the adverse effects of starvation than females (491). Thus, a second purpose of this work is to determine if the thyroid hormone response to IGF-1 is sex-dependent.

\section{Materials and Methods}

\section{General}

All sheep used in these studies were of Suffolk or Dorset breeding and were approximately 9 months of age. They were housed indoors in light (14L:10D) and temperature controlled rooms and fed ad libitum a diet consisting of alfalfa pellets supplemented with cracked corn. Animals had unlimited access to water at all times. All procedures were approved by the West Virginia University Animal Care and Use Committee and followed NIH guidelines for use of animals in research.

\section{Experiment 1}

The purpose of this experiment was to determine if chronic administration of IGF1 stimulates $T_{4}$ and $T_{3}$ secretion in food-deprived females. Fourteen ewes were ovariectomized two weeks prior to the beginning of the study. At the time of ovariectomy, each ewe received a length of silastic tubing (Sil-Med, Tri-anim, Sylmar, $\mathrm{CA}$; inner diameter $3.35 \mathrm{~mm}$, outer diameter $4.65 \mathrm{~mm}$ ) packed with $1 \mathrm{~cm}$ of crystalline $\beta$ estradiol (Sigma-Aldridge Inc., St Louis MO) and closed at both ends with silicone sealant. Two weeks prior to the study, animals were group-housed with each pen holding five animals. Ewes were provided a normal meal on the morning of Day 0 and allowed time to eat after which they received no food for the remainder of the 6-day period of food withdrawal. Animals were allocated to three treatment groups with assignment balanced for body weight on Day 0: 1) food-deprived control $(n=5), 2)$ food-deprived and receiving $10 \mathrm{ug} / \mathrm{kg} / \mathrm{d}$ IGF-1 (IGF-10; n=5), and 3) food-deprived and receiving $50 \mathrm{ug} / \mathrm{kg} / \mathrm{d}$ 
IGF-1 (IGF-50; n=4). Animals receiving IGF-1 were administered long R3-IGF-1 (GroPep Ltd, Adelaide, Australia), an IGF-1 analog with reduced affinity for IGF-1 binding proteins, subcutaneously twice daily at $0800 \mathrm{~h}$ and $2000 \mathrm{~h}$ beginning on Day 4 of food removal. Weights were recorded at $0800 \mathrm{~h}$ and three blood samples were collected via jugular venipuncture every 2 hours over a 4-hour period beginning at $0900 \mathrm{~h}$ on days $0,2,4$, and 6 . Samples were allowed to sit overnight, were centrifuged, and the serum was removed and frozen at $-20^{\circ} \mathrm{C}$. Samples were analyzed for total $\mathrm{T}_{4}$, total $\mathrm{T}_{3}$, insulin, and glucose.

\section{Experiment 2}

The purpose of this study was to determine if IGF-1 acutely stimulates total $\mathrm{T}_{4}$ and total $\mathrm{T}_{3}$ secretion. Similar to Experiment 1, ovariectomized ewes were food deprived for 6 days. On Day 6, IGF-1 was administered as a single intravenous bolus at a dose of $6.5 \mathrm{ug} / \mathrm{kg}(\mathrm{n}=5), 12.5 \mathrm{ug} / \mathrm{kg}(\mathrm{n}=5)$, or $25 \mathrm{ug} / \mathrm{kg}(\mathrm{n}=5)$. Blood samples were collected every 12 minutes from just prior to IGF-1 injection ( 0 minutes) to 60 minutes following IGF-1 injection, and a single sample was collected 120 minutes post-injection. Blood samples were processed as above and total $\mathrm{T}_{4}$ and total $\mathrm{T}_{3}$ were assessed for each sample.

\section{Experiment 3}

The purpose of this experiment was to determine the effect of chronic IGF-1 administration on $T_{4}$ and $T_{3}$ secretion in food-deprived males. Two weeks prior to the study, 28 wethers were each implanted with a $1 \mathrm{~cm}$ estradiol implant and were grouphoused with each pen holding 6 animals. Wethers were provided a normal meal on the morning of Day 0 and allowed time to eat after which they received no food for the remainder of the 4-day period of food withdrawal. Wethers were divided into four 
treatment groups initially balanced for body weight on Day 0:1) food-deprived control group ( $\mathrm{n}=6)$, 2) food-deprived and receiving $25 \mathrm{ug} / \mathrm{kg} / \mathrm{d}$ IGF-1 (IGF-25; n=6), 3) fooddeprived and receiving $50 \mathrm{ug} / \mathrm{kg} / \mathrm{d}$ IGF-1 (IGF-50; $\mathrm{n}=6$ ), or 4) food-deprived and receiving $100 \mathrm{ug} / \mathrm{kg} / \mathrm{d}$ IGF-1 (IGF-100; $\mathrm{n}=5)$. Animals receiving IGF-1 were administered long R3-IGF-1 (GroPep Ltd, Adelaide, Australia) subcutaneously twice daily at $0800 \mathrm{~h}$ and $2000 \mathrm{~h}$ beginning on day 1 . Weights were recorded at $0800 \mathrm{~h}$ and blood samples were collected via jugular venipuncture every 2 hours over a 4-hour period beginning at $0900 \mathrm{~h}$ on days 0,2 , and 4 . Samples were allowed to sit overnight, were centrifuged, and the serum was removed and frozen at $-20^{\circ} \mathrm{C}$. Samples were analyzed for total $\mathrm{T}_{4}$, total $\mathrm{T}_{3}$, insulin, and glucose.

\section{Hormone Assays}

Total $\mathrm{T}_{4}$ was assessed using a commercially available kit from Diagnostic Products Corporation (Los Angeles, CA). For males, all samples within an experiment were run in duplicate within one assay. The intraassay coefficient of variation was $10.6 \%$ with sensitivity being $0.1 \mathrm{ng} / \mathrm{ml}$. For females, three assays were performed with sensitivity being $0.1 \mathrm{ng} / \mathrm{ml}$ and interassay and intrassay coefficients of variation being $14.3 \%$ and $7.0 \%$, respectively. Total $\mathrm{T}_{3}$ was assessed using a commercially available kit from Diagnostic Products Corporation. For males, all samples within an experiment were run in duplicate within one assay. The intraassay coefficient of variation was $4.2 \%$ with sensitivity being $2 \mathrm{ng} / \mathrm{dl}$. For females, 2 assays were performed with sensitivity being 2 $\mathrm{ng} / \mathrm{dl}$ and interassay and intrassay coefficients of variation being $7.2 \%$ and $5.5 \%$, respectively. Insulin was assessed using a commercially available kit from Linco Research Inc. (St. Charles, MO). All samples within an experiment were run in duplicate 
within one assay. The intraassay coefficient of variation was $6.6 \%$ with sensitivity being $0.1 \mathrm{ng} / \mathrm{ml}$. Serum glucose levels were measured spectrophotometrically in singlet using the Trinder reagent kit and performed according to manufacturer's instructions (Sigma Diagnostics Inc., St. Louis MO).

\section{Statistical Analysis}

Values for individual samples were averaged to provide a mean for each animal within each blood collection period (or day). Data for body weight, total $\mathrm{T}_{4}$, total $\mathrm{T}_{3}$, insulin, and glucose were analyzed by two-way ANOVA for repeated measures to determine the effects of time, dose of IGF-1, and their interaction. Those groups showing a significant time $\mathrm{x}$ dose interaction were further analyzed by one way analysis of variance followed by a test of least significance difference to determine influence of IGF1 dose among groups within each day, and by one way repeated measures followed by a Student-Newman-Keuls test to determine the effect of time within each group over the 4 or 6 day treatment period for males or females, respectively. In addition, for Experiment 2, Dunnet's method was used to compare post-injection time period means to the control period (0 minutes).

\section{$\underline{\text { Results }}$}

Experiment 1

As expected, food deprivation caused a significant $(\mathrm{P}<0.05)$ decrease in body weight (Figure 1). The percent change in body weight did not differ among groups ( $\mathrm{P}>0.10)$. Collectively, ewes lost $14.4 \pm 1.56 \%$ of their initial body weights over the 6 day period of food withdrawal. 
Changes in total circulating $\mathrm{T}_{4}$ and $\mathrm{T}_{3}$ in ewes are illustrated in Figure $2 \mathrm{~A}$ and $2 \mathrm{~B}$, respectively. As expected, circulating levels of both $\mathrm{T}_{4}$ and $\mathrm{T}_{3}$ were decreased $(\mathrm{P}<0.05)$ in controls by food deprivation. In contrast, treatment with IGF-1 elevated total circulating $\mathrm{T}_{4}$ levels by day 6 of food removal in a dose dependent manner. Total $\mathrm{T}_{4}$ levels for IGF-50 ewes were elevated $(\mathrm{P}<0.05)$ above their Day 0 values and were greater $(\mathrm{P}<0.05)$ than Day 6 values for controls. Values for IGF-10 ewes were returned to their Day 0 values by IGF-1 treatment and were intermediate of controls and IGF-50 ewes on Day 6. Likewise, IGF-1 increased circulating $\mathrm{T}_{3}$ in a dose-dependent manner. Total $\mathrm{T}_{3}$ levels in all groups differed significantly $(\mathrm{P}<0.05)$ from each other on day 6 and total $\mathrm{T}_{3}$ was returned to Day 0 values in IGF-10 ewes and exceeded Day 0 values in IGF-50 ewes.

As expected, insulin concentrations (Figure 3A) decreased $(\mathrm{P}<0.01)$ in fooddeprived females. Insulin levels were lower $(\mathrm{P}<0.05)$ in IGF-1 treated groups compared to controls on days 4 and 6 , though there was no significant difference $(\mathrm{P}<0.10)$ between IGF-1 treated groups. Glucose levels (figure 3B) dropped slightly, but significantly $(\mathrm{P}<0.01)$ over time in food-deprived controls. Effects of IGF-1 on circulating glucose levels were dependent upon dose. Glucose dropped $(\mathrm{P}<0.01)$ over time in the IGF-10 group, but values were not different than controls $(\mathrm{P}>0.05)$. Glucose levels were lower $(\mathrm{P}<0.05)$ on days 4 and 6 in the IGF-50 group than either controls or the IGF-10 group.

\section{Experiment 2}

Total $\mathrm{T}_{4}$ values in ewes receiving intravenous injections of IGF-1 are shown in Figure 4A. ANOVA revealed a significant effect of period $(\mathrm{P}<0.001)$, but no significant effect of dose $(\mathrm{P}>0.60)$ or dose $\mathrm{x}$ period interaction $(\mathrm{P}>0.60)$. Total $\mathrm{T}_{4}$ levels were increased $(\mathrm{P}<0.05)$ over 0 minute control values at 60 and 120 minutes post-injection. 
Total $T_{3}$ values in ewes receiving intravenous injections of IGF-1 are shown in Figure 4B. ANOVA revealed a significant effect of period $(\mathrm{P}<0.001)$, but no significant effect of dose $(\mathrm{P}>0.30)$ or dose $\mathrm{x}$ period interaction $(\mathrm{P}>0.20)$. Total $\mathrm{T}_{3}$ concentrations were increased $(\mathrm{P}<0.05)$ over 0 minute control values at 36, 48, 60 and 120 minutes postinjection.

\section{Experiment 3}

As expected, food removal for 4 days resulted in a significant $(\mathrm{P}<0.001)$ loss of body weight (Figure 5). The percent change in body weight did not differ $(\mathrm{P}>0.80)$ among treatment groups with males losing $12.49 \pm 0.90 \%$ of their initial body weight over the 4 day food withdrawal period.

Total $\mathrm{T}_{4}$ values (Figure $6 \mathrm{~A}$ ) in controls progressively decreased $(\mathrm{P}<0.05)$ on each day of food removal. Compared to day 0 values, Total $\mathrm{T}_{4}$ values on day 2 for IGF- 25 and IGF-50 males were not significantly different $(\mathrm{P}>0.10)$, but were increased $(\mathrm{P}<0.05)$ slightly in IGF-100 males. Total $\mathrm{T}_{4}$ levels decreased $(\mathrm{P}<0.05)$ in all IGF-1 treated groups on day 4 compared to day 2 . However, total $\mathrm{T}_{4}$ was significantly $(\mathrm{P}<0.01)$ higher for all IGF-1 treated groups than controls on day 2 and remained so on day 4 . Total $\mathrm{T}_{3}$ levels (Figure 6B) progressively declined $(\mathrm{P}<0.05)$ in both control males and IGF-25 animals. Total $T_{3}$ in the IGF-50 males did not differ from Day 0 levels until Day 4 of food removal $(\mathrm{P}<0.05)$. Although total T3 levels decreased in IGF-100 males over time, this reduction was not statistically significant $(\mathrm{P}>0.10)$. Total $\mathrm{T}_{3}$ levels did not differ $(\mathrm{P}>0.20)$ between treatment groups on Day 2. On Day 4 , total $\mathrm{T}_{3}$ values were higher $(\mathrm{P}<0.05)$ in IGF-50 and IGF-100 males than in control males. Total $\mathrm{T}_{3}$ levels in IGF-25 wethers were 
intermediate of those in controls and IGF-50, i.e. levels in IGF-25 males were not significantly different $(\mathrm{P}>0.05)$ from either control or IGF-50 males.

Insulin levels (Figure 7A) dropped below assay sensitivity by day 2 of food removal and remained undetectable in all groups. Circulating glucose levels (Figure 5b) decreased $(\mathrm{P}<0.05)$ in control, IGF-25, and IGF-50 males on day 2 and 4 compared to day 0 . In the IGF-100 males, circulating glucose concentration on days 0 and 2 were similar $(\mathrm{P}>0.05)$, but glucose levels dropped significantly on day $4(\mathrm{P}<0.05)$. Glucose levels among groups were not significantly different $(\mathrm{P}>0.05)$ on Day 2 . Glucose levels were similar $(\mathrm{P}>0.05)$ between IGF-50 and IGF-100 males on Day 4 and both were significantly $(\mathrm{P}<0.05)$ lower than either controls or IGF-25 males, which did not differ from each other $(\mathrm{P}>0.05)$.

\section{Discussion}

In order to determine the effect of IGF-1 on circulating thyroid hormone concentrations, we administered exogenous IGF-1 to food-deprived sheep in three separate experiments, two using females and one using males. The results from these studies support our hypothesis that IGF-1 increases thyroid hormone levels during food deprivation. Furthermore, results from these experiments show that food deprivation has a greater impact on males than females and that the thyroid hormone response to IGF-1 during food deprivation is much greater in females. These data are consistent with the idea that females are much more able to cope with energy perturbations than males and further suggest that changes in IGF-1 may provide a signal linking nutritional status with basal metabolic rate through an alteration in circulating thyroid hormone levels. 
Animals on the current study lost $12 \%$ (males) and 14\% (females) of their initial body weight over a four or six day period of food deprivation, respectively. Although it is difficult to directly compare the males and females in our studies since the experiments were performed in differing years, the rate of weight loss appeared to be very similar for males and females and consistent with previous work (319). In keeping with past reports in several species, food deprivation caused a significant decrease in total $T_{4}$ and $T_{3}$ (160;252-255). Circulating concentrations of total $\mathrm{T}_{4}$ appeared to be higher on day 0 in males than in females and decreased more dramatically in males than females with food deprivation. In contrast, circulating levels of total $\mathrm{T}_{4}$ increased in IGF-1 treated females, reaching Day 0 levels in ewes treated with $10 \mathrm{ug} / \mathrm{kg} / \mathrm{d}$ and exceeding Day 0 levels in ewes treated with $50 \mathrm{ug} / \mathrm{kg} / \mathrm{d}$. Females also demonstrated a dramatic and dose-related increase in total circulating $\mathrm{T}_{3}$ levels following IGF-1 treatment. In contrast, IGF-1 treated males were able to maintain total $T_{4}$ levels until Day 2 , after which circulating $T_{4}$ dropped. Nonetheless, values in IGF-1 treated males remained above control values suggesting that IGF-1 has the ability, albeit limited, to influence thyroid hormone levels in food deprived males. Likewise, IGF-1 appeared to slow, in a dose-dependent fashion, the decrease in $T_{3}$ levels observed with fasting in males. Based on these data, we would conclude that IGF-1 is a more potent stimulus of thyroid hormone levels in females than in males.

The site of action at which IGF-1 stimulates thyroid hormone secretion as well as the mechanism whereby this occurs is at present unknown. Very few studies have addressed how IGF-1 or its secretagogue, GH, influence the HPT axis. Theoretically, IGF-1 could influence thyroid hormone levels by acting at all levels of the HPT axis 
since IGF-1 receptor protein or mRNA has been localized to the hypothalamus and pituitary (189), and the thyroid gland (492). To our knowledge, there is no data available as to whether IGF-1 influences TRH release. A limited number of reports suggest that GH or IGF-1 can inhibit pituitary TSH release (487;493-495). Klinger et al. (490) showed that either a bolus i.v. or subcutaneous injection of IGF-1 reduced TSH levels and proposed that this was due to increased somatostatin release. However, another study by Trainer (496) observed decreased TSH levels after IGF-1 treatment without significant changes in GH release and the author suggested that the suppression in TSH was due to elevated $T_{4}$ and $T_{3}$. Our data are consistent with this explanation. A direct action of IGF-1 at the pituitary is suggested by studies showing altered sensitivity to TRH stimulation following GH or IGF-1 treatment $(488 ; 497 ; 498)$. We did not measure TSH in our study. TSH is difficult to detect in serum collected from thyroid-intact sheep (Dr. Fred Karsch, personal communication), a fact confirmed by our attempt to measure TSH with a commercially available assay. Further study will be needed to address the issue of where IGF-1 acts to increase thyroid hormone levels.

In both females and males, circulating levels of total $\mathrm{T}_{3}$ appeared to follow closely serum levels of total $T_{4}$. This is not too surprising since at least $75 \%$ of all circulating $T_{3}$ is derived from $\mathrm{T}_{4}$ by peripheral 5 '-deiodination rather than from thyroid gland secretion $(257 ; 499 ; 500)$. The finding for females that total $T_{3}$ levels increased prior to total $T_{4}$ levels in our second experiment suggests that IGF-1 stimulates deiodinase activity. This is consistent with previous work indicating that GH or IGF-1 treatment stimulates the conversion of $T_{4}$ to $T_{3}$. Salamon et al. (501) observed that GH-deficient adults treated with $\mathrm{GH}$ and who were on fixed doses of $\mathrm{T}_{4}$ replacement therapy developed 
thyrotoxicosis associated with a rise in plasma $T_{3}$ values. Grunfeld et al. (502) reported that normal subjects treated with $\mathrm{GH}$ exhibited a decrease in $\mathrm{TSH}$ and $\mathrm{T}_{4}$, but increased $\mathrm{T}_{3}$ levels. Other studies have also reported increased $\mathrm{T}_{3}$ but decreased $\mathrm{T}_{4}(487 ; 488)$, or increased $\mathrm{T}_{3}$ without a change in $\mathrm{T}_{4}(489 ; 495)$ following hGH or IGF-1 administration. Alternatively, increased $T_{3}$ levels may have simply been due to increased precursor $T_{4}$ levels without a change in deiodinase activity. Despite the fact that $T_{3}$ levels increased within 1 hour of IGF-1 administration, total $\mathrm{T}_{4}$ levels remained constant, suggesting that $\mathrm{T}_{4}$ secretion likely was also being stimulated at this time. Indeed, total $\mathrm{T}_{4}$ levels increased significantly once total $\mathrm{T}_{3}$ levels reached their maximum. Thus, the IGF-1induced increase in total $\mathrm{T}_{3}$ levels observed for females in our study may result from an increase in precursor $\mathrm{T}_{4}$ levels and/or an increase in deiodinase activity.

Most of the $T_{3}$ and $T_{4}$ that is transported in blood is bound to thyroid hormone binding proteins $(503 ; 504)$. Since only the unbound, or free, hormones are able to enter and affect cells, bound $\mathrm{T}_{3}$ and $\mathrm{T}_{4}$ is inactive until being released as free hormone into plasma (505). Since we measured total $\mathrm{T}_{3}$ and $\mathrm{T}_{4}$ in circulation, we did not assess whether free $T_{3}$ or $T_{4}$ changed with IGF-1 treatment. However, we would speculate that our measurements of total $\mathrm{T}_{3}$ and $\mathrm{T}_{4}$ are of biological relevance for at least two reasons. One is that in previous work examining the effect of GH or IGF-1 on thyroid hormone release, the change in total hormone reflected that of free hormone $(487 ; 495 ; 506)$. Two, previous studies have shown no effect of GH administration on serum thyroglobulin levels (487) or capacity (489).

As expected, insulin decreased following food deprivation. However, the change in insulin appeared to be influenced by both gender and IGF-1 treatment. In control 
females, insulin levels decreased yet were clearly detectable on day 4 of food withdrawal and did not change through Day 6. However, concentrations of insulin decreased to assay sensitivity by Day 2 of food removal in control males. This is consistent with the idea that males respond more robustly than females to food removal. On days 4 and 6 of food removal, both IGF-10 and IGF-50 females exhibited lower circulating insulin concentrations than control females. For IGF-50 females, this drop in insulin may be related to an accompanying drop in blood glucose levels, perhaps due to the insulin-like actions of IGF-1 (507;508). However, glucose levels in controls and IGF-10 females were similar, suggesting that IGF-1 increased insulin sensitivity at this lower dose. This is consistent with a previous study wherein IGF-1 decreased circulating insulin levels although there was no change in glucose concentrations (494). In males, since insulin levels dropped so quickly it was not possible to determine if IGF-1 had any effect on insulin levels.

In summary, though body weight loss following food removal was relatively similar between males and females, changes in circulating insulin, total $\mathrm{T}_{4}$, and total $\mathrm{T}_{3}$ were sex-dependent. Insulin, $\mathrm{T}_{4}$, and $\mathrm{T}_{3}$ levels decreased more quickly and to a greater degree in food-deprived males than in food-deprived females. These results suggest that males react more strongly to food deprivation and that females may be better able to deal, in an energetic sense, with this type of perturbation in energy supply. Both sexes demonstrated an increase in $\mathrm{T}_{3}$ and $\mathrm{T}_{4}$ over controls following IGF-1 treatment. Total $\mathrm{T}_{4}$ and $\mathrm{T}_{3}$ levels in females were increased to or beyond Day 0 control values after three days of IGF-1 treatment. In contrast, during IGF-1 treatment, total $\mathrm{T}_{4}$ and $\mathrm{T}_{3}$ levels were maintained in males for 2 days, after which they declined significantly. This response 
was observed even though males received similar or an even higher doses of IGF-1 as the females. Based on these data, we would conclude that IGF-1 is a more potent stimulus of thyroid hormone levels in females than in males. Further study is needed to determine the mechanisms which underlie this sex-dependent response to IGF-1. 
Figure 1

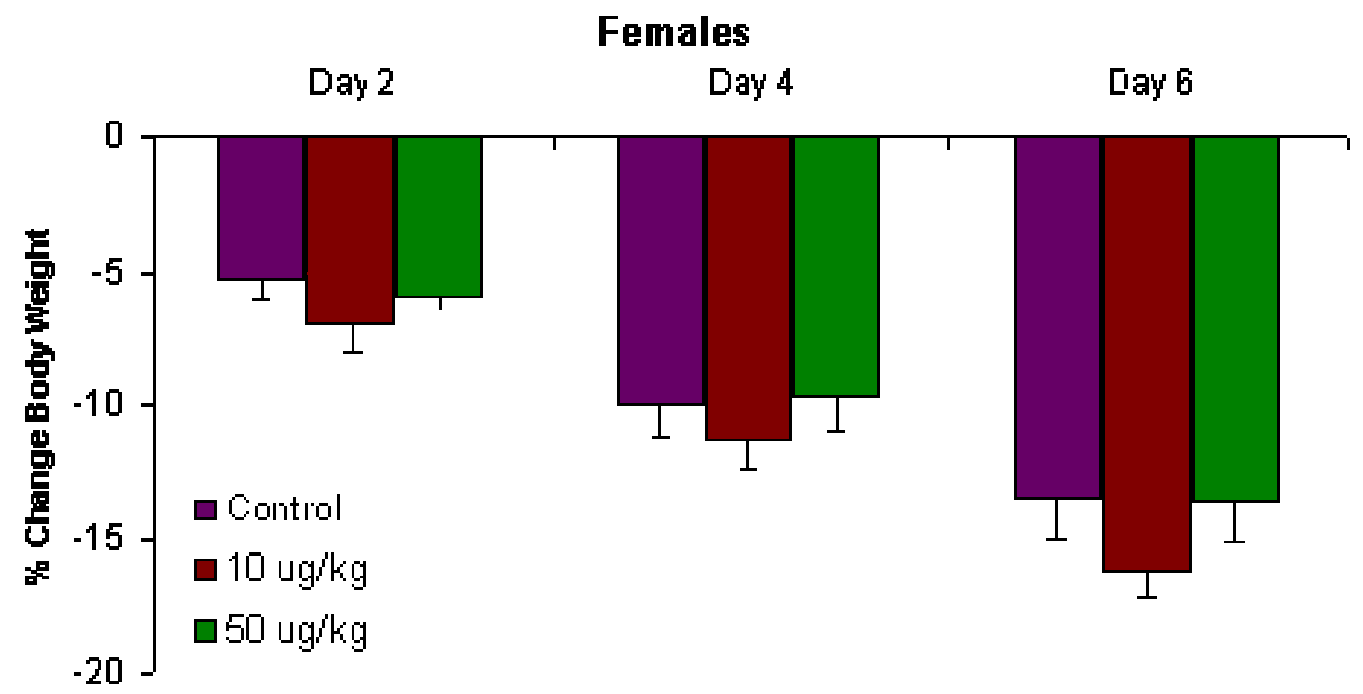


Figure 2

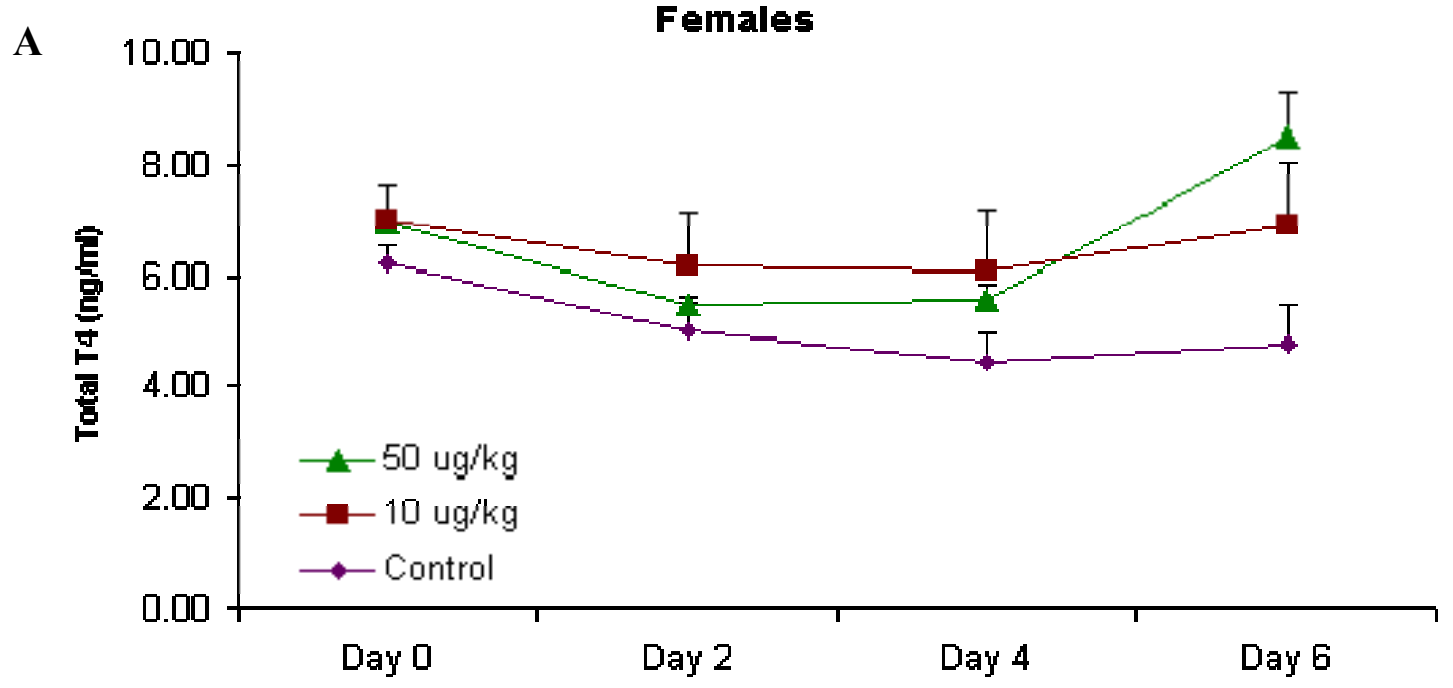

Females

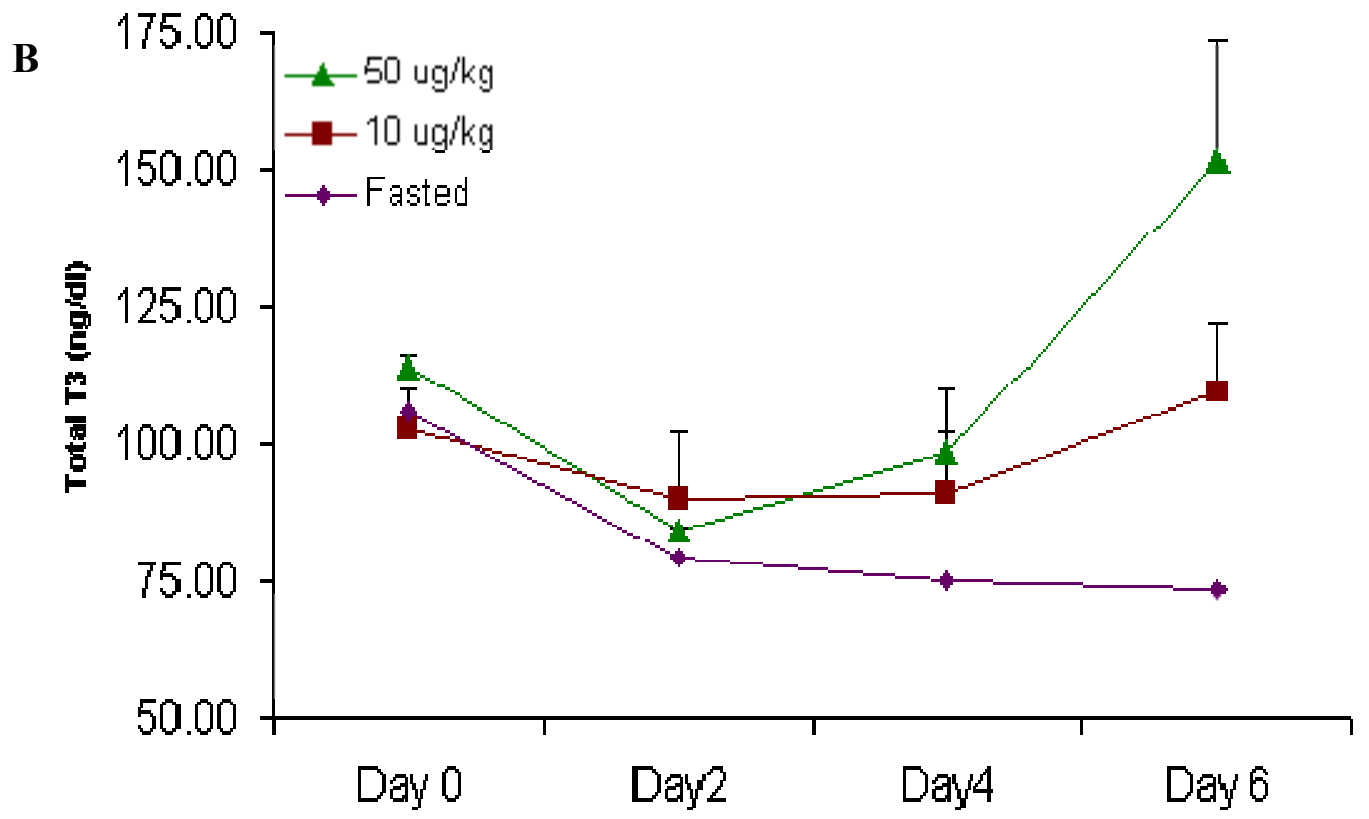




\section{Figure 3}
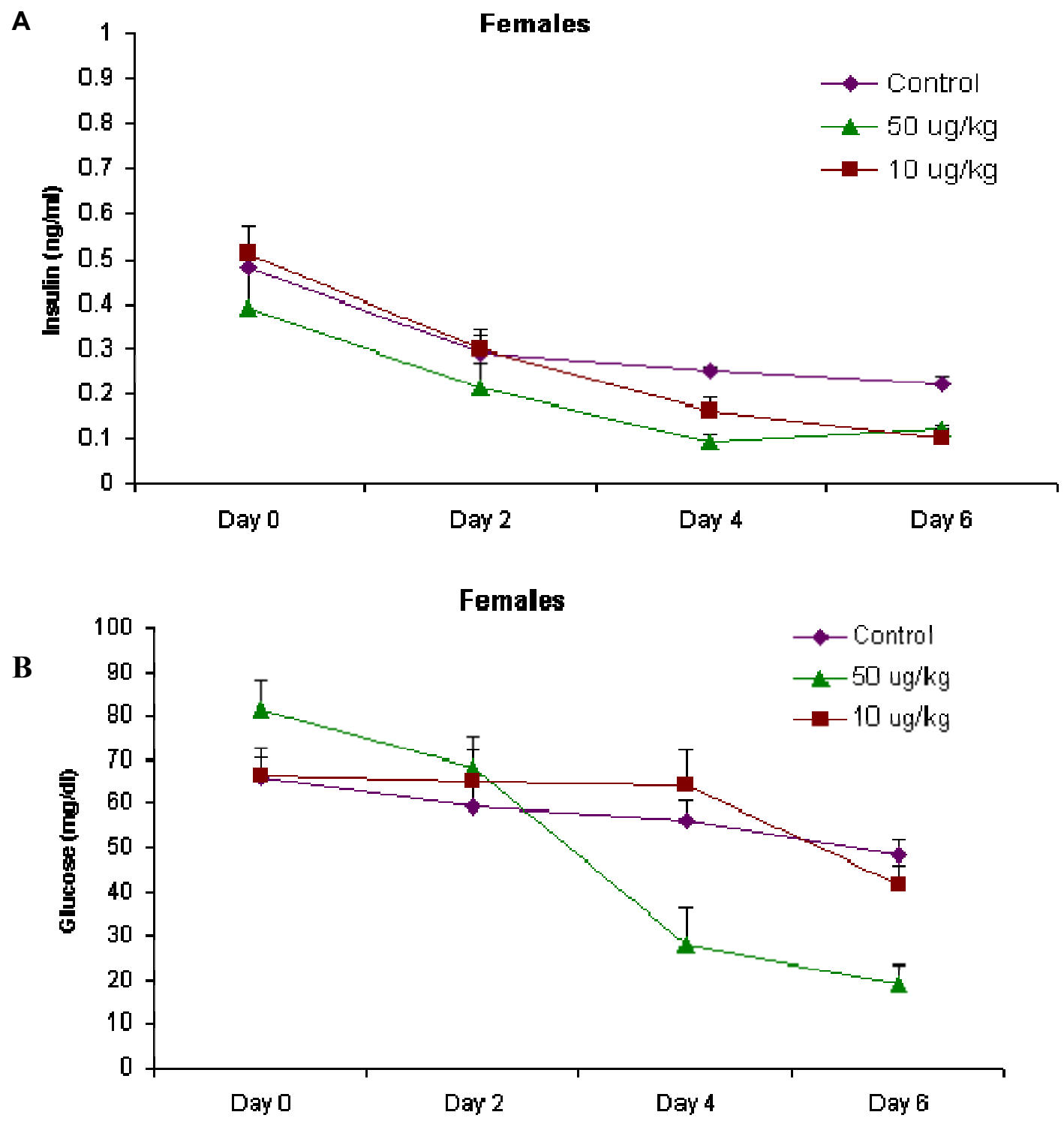
Figure 4

A

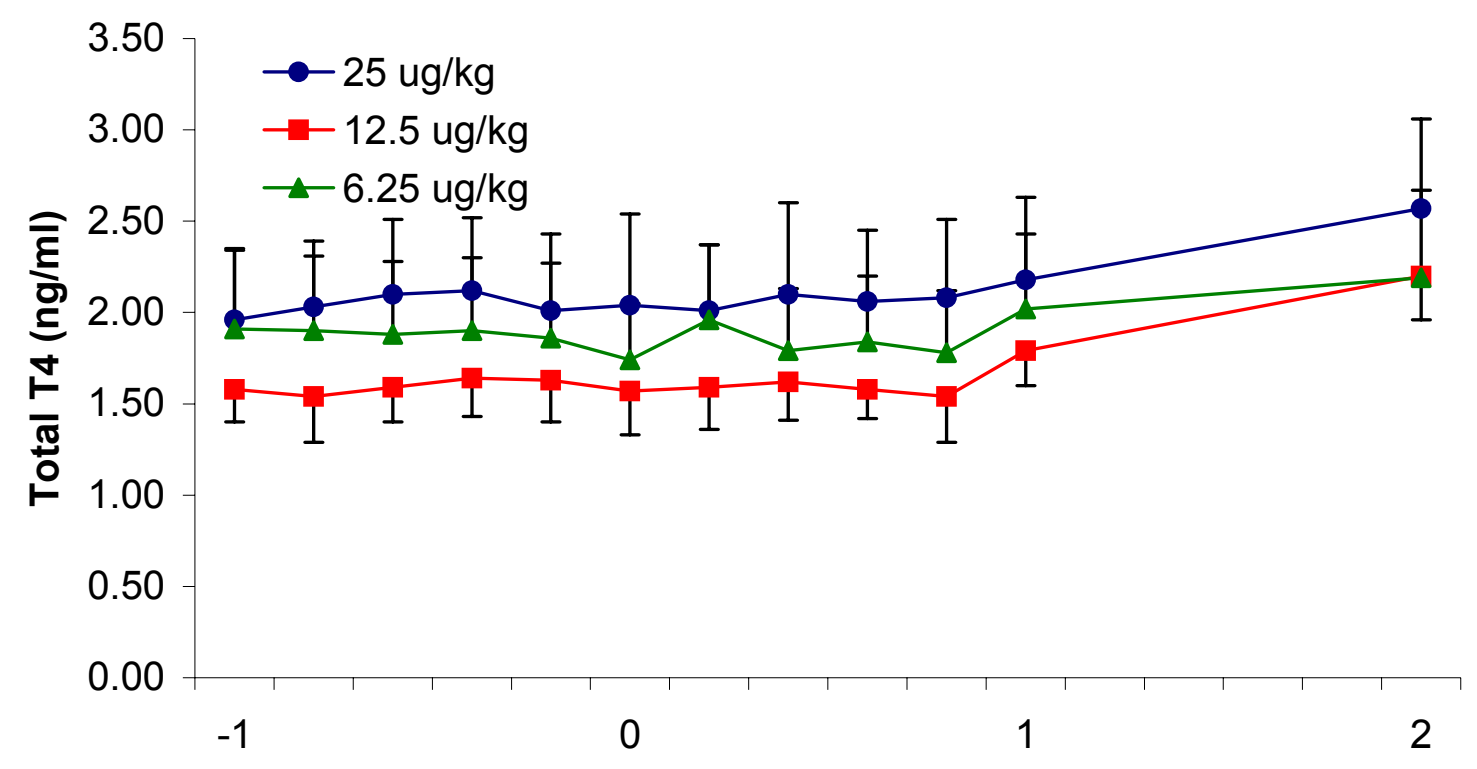

B

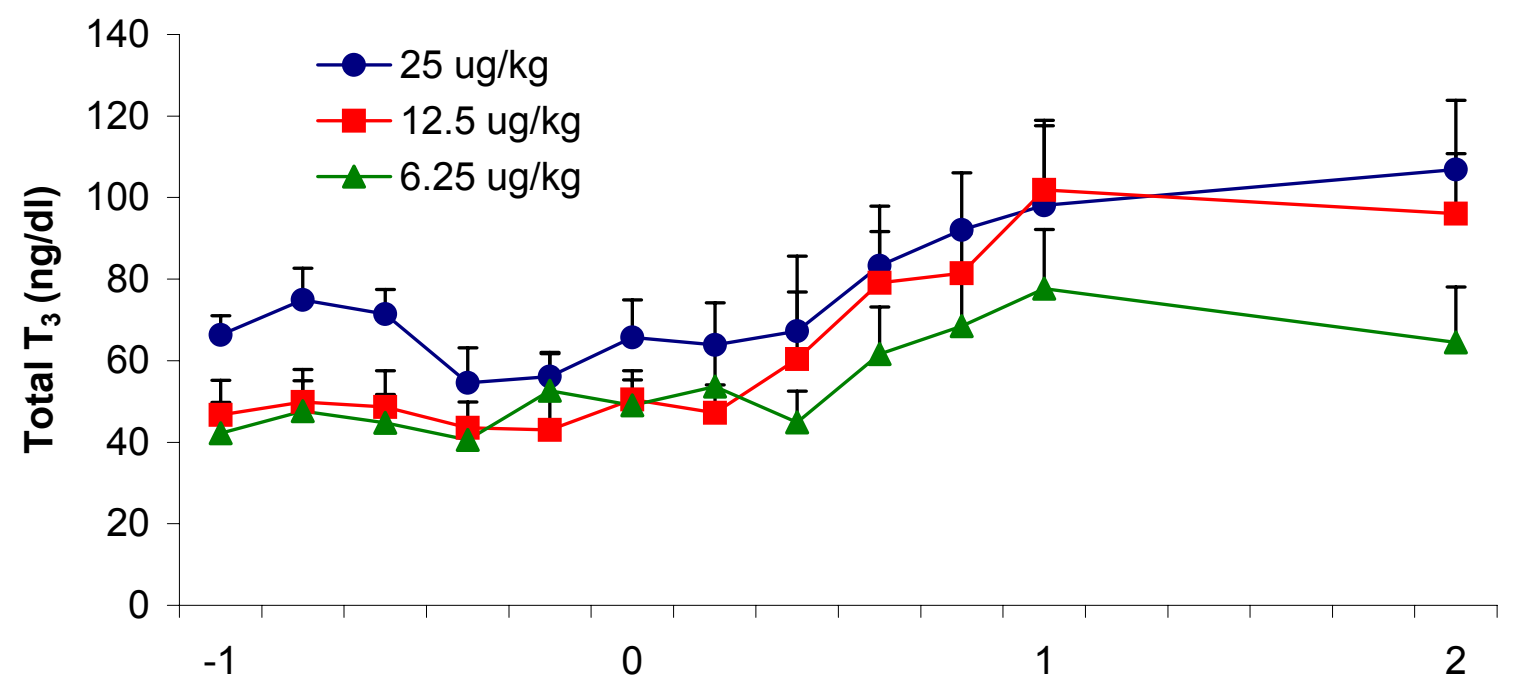


Figure 5

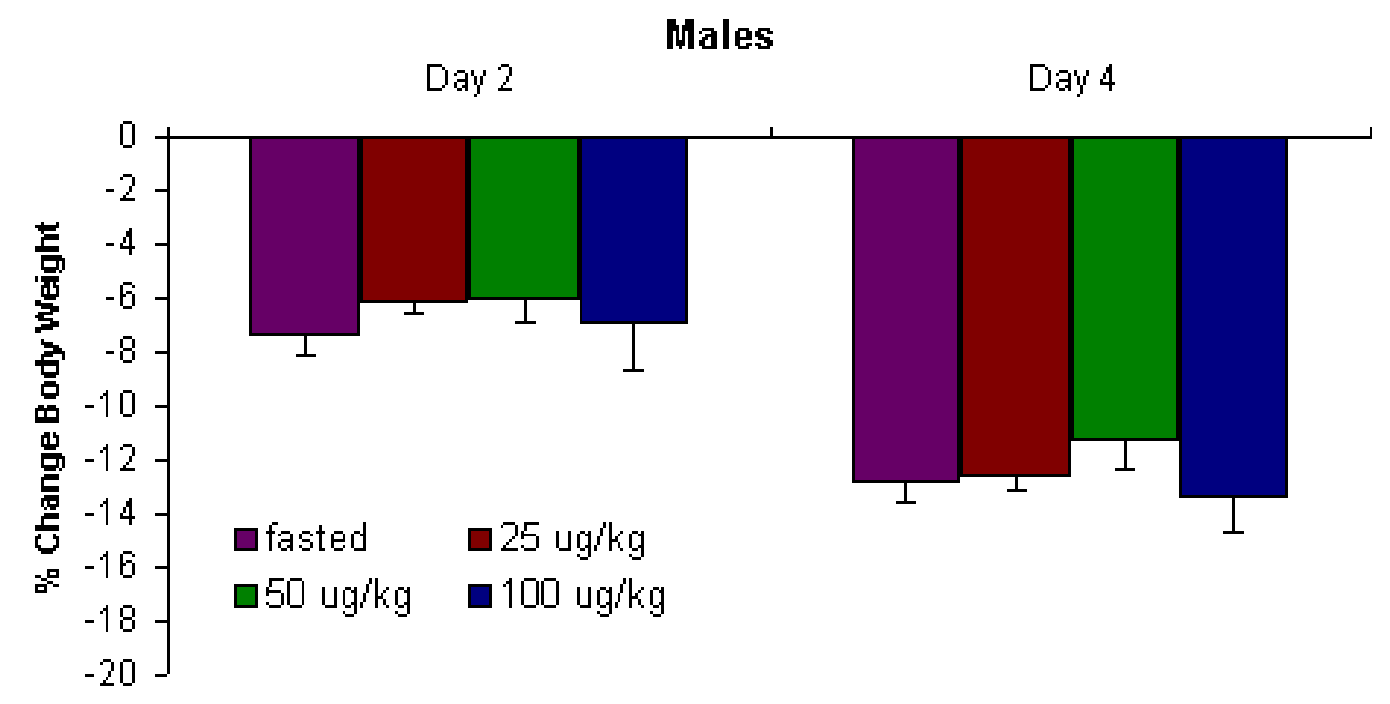




\section{Figure 6}
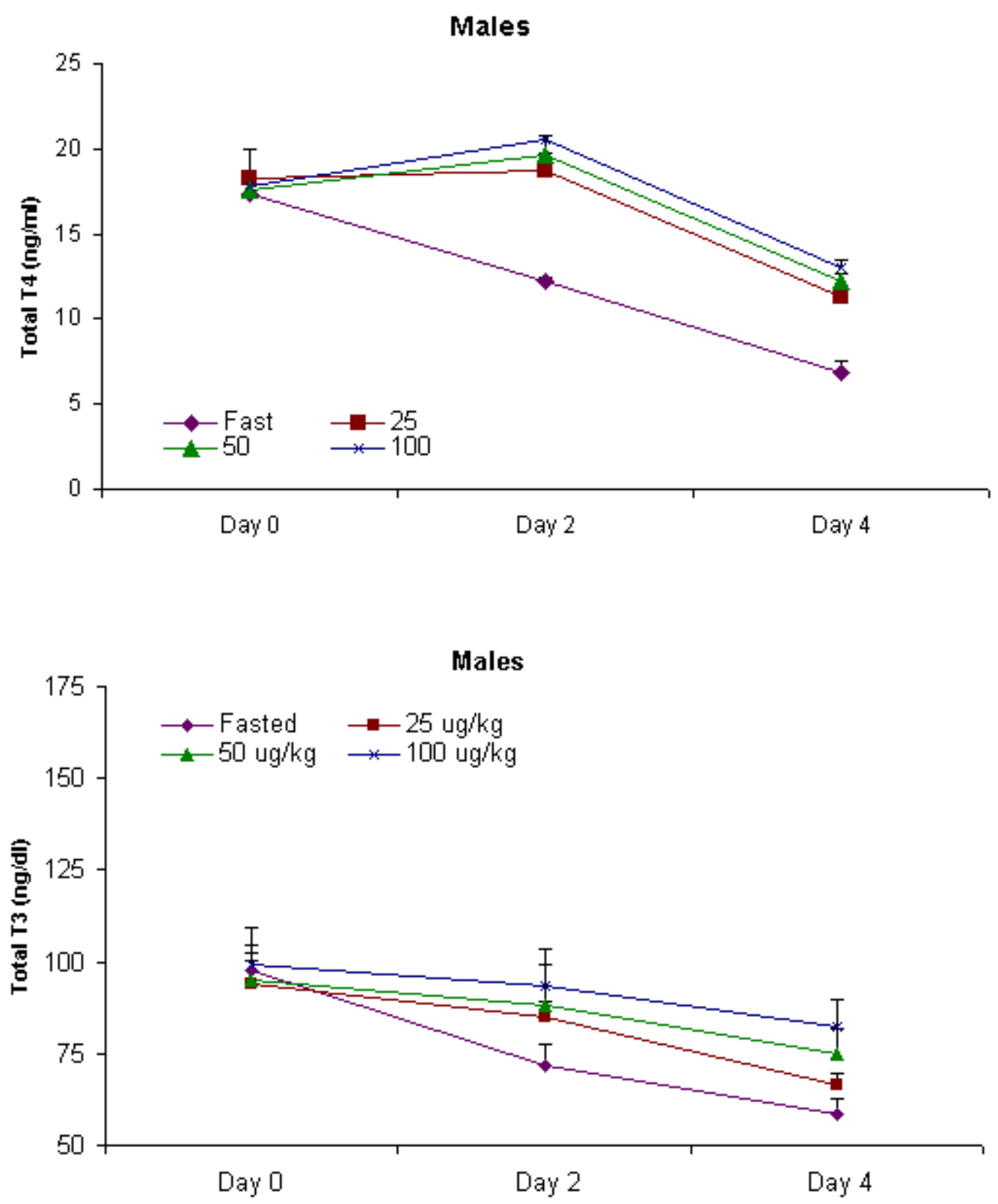
Figure 7
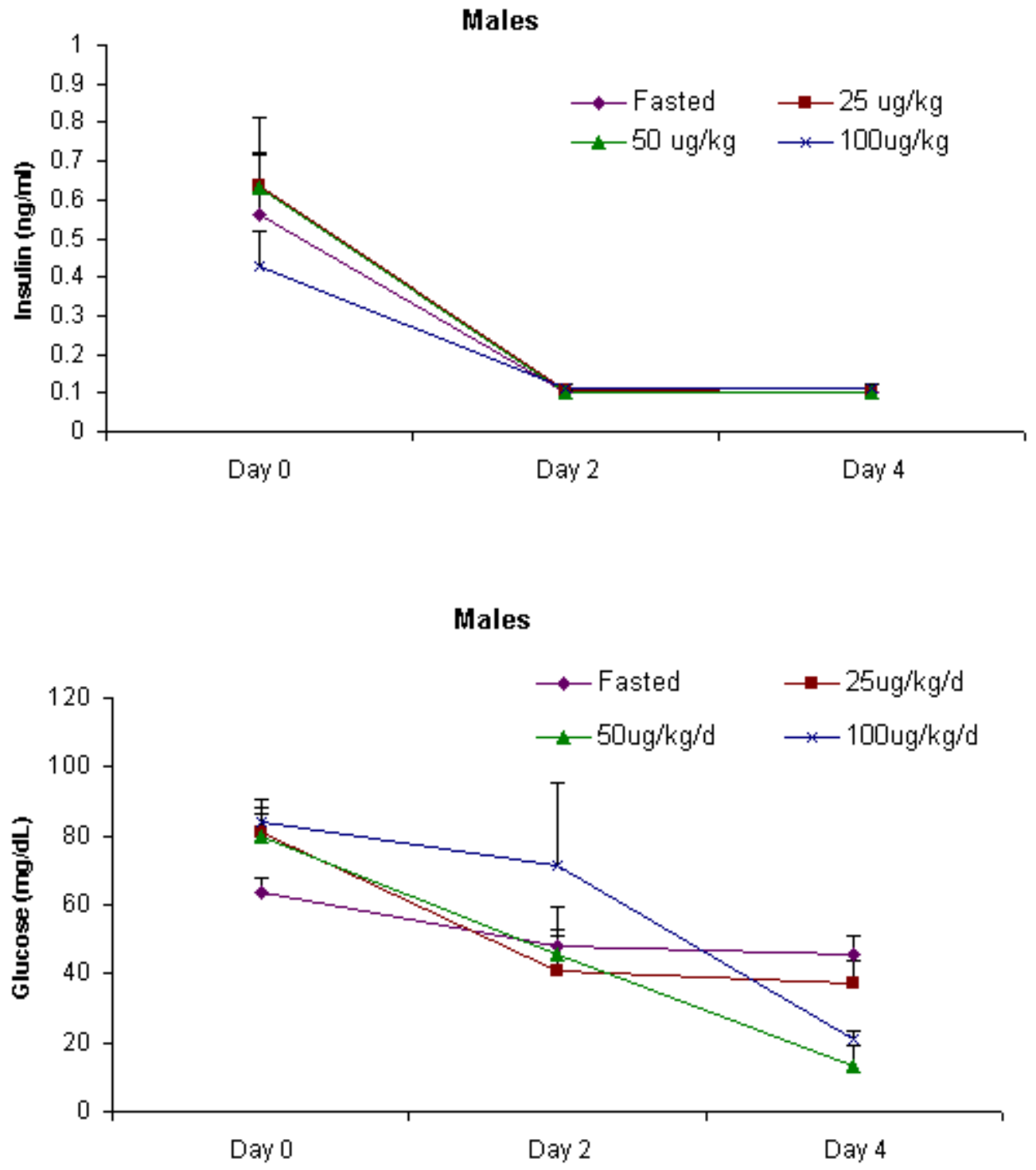
Figure 1

A) Percent change from Day 0 body weight on Day 2 and Day 4 of food removal in controls or wethers receiving IGF-1 subcutaneously twice daily at $25 \mathrm{ug} / \mathrm{kg} / \mathrm{d}, 50 \mathrm{ug} / \mathrm{kg} / \mathrm{d}$, or $100 \mathrm{ug} / \mathrm{kg} / \mathrm{d}$ beginning on Day 1 . Weight loss increased over time $(\mathrm{P}<0.001)$, but did not differ among the four groups $(\mathrm{P}>0.80)$. B) Percent change from Day 0 body weight on Day 2, Day 4, and Day 6 of food removal in controls or ewes receiving IGF-1 at either $10 \mathrm{ug} / \mathrm{kg} / \mathrm{d}$ or $50 \mathrm{ug} / \mathrm{kg} / \mathrm{d}$ subcutaneously twice daily beginning on Day 3. Weight loss did not differ $(\mathrm{P}>0.10)$ for the three groups.

Figure 2

Circulating levels of Total $\mathrm{T}_{3}$ and Total $\mathrm{T}_{4}$ during 6 days of food removal in controls or ewes receiving IGF-1 subcutaneously twice daily at $10 \mathrm{ug} / \mathrm{kg} / \mathrm{d}$ or $50 \mathrm{ug} / \mathrm{kg} / \mathrm{d}$ beginning on Day 3. A) Total $\mathrm{T}_{4}$ in control animals differed from IGF-1 treated groups on Day 2 $(\mathrm{P}<0.006)$ and Day $4(\mathrm{P}<0.007)$. Total $\mathrm{T}_{4}$ increased from Day 0 levels on Day 2 in animals treated with $100 \mathrm{ug} / \mathrm{kg} / \mathrm{d}$ IGF-1 $(\mathrm{P}<0.05)$ and decreased in all groups on Day 4 when compared to Day 2. B) Total $\mathrm{T}_{3}$ levels in all groups did not differ significantly on Days 0,2 , or $4(\mathrm{P}>0.05)$, but were significantly different from each other $(\mathrm{P}<0.05)$ on Day 6.

Figure 3

Insulin and glucose levels during 6 days of food removal in controls or ewes receiving IGF-1 at $10 \mathrm{ug} / \mathrm{kg} / \mathrm{d}$ or $50 \mathrm{ug} / \mathrm{kg} / \mathrm{d}$ subcutaneously twice daily beginning on Day 3. A) Insulin levels in control ewes decreased from initial levels on Day 2 and remained consistent at that level for the remainder of the treatment period. Insulin levels were not significantly different between treated groups $(\mathrm{P}>0.05)$ but were lower $(\mathrm{P}<0.05)$ in IGF-1 treated groups compared to controls on Days 4 and 6 of fasting. B) Glucose did not differ between $10 \mathrm{ug} / \mathrm{kg} / \mathrm{d}$ and control groups, and remained the same throughout the treatment. Day 4 and 6 glucose values were lower than Day 0 and 2 values $(P<0.05)$, and were lower than either of the other groups on Days 4 and $6(\mathrm{P}<0.05)$.

Figure 4

Circulating levels of Total $\mathrm{T}_{3}$ and Total $\mathrm{T}_{4}$ during 4 days of food removal in controls or wethers receiving IGF-1 at $25 \mathrm{ug} / \mathrm{kg} / \mathrm{d}, 50 \mathrm{ug} / \mathrm{kg} / \mathrm{d}$, or $100 \mathrm{ug} / \mathrm{kg} / \mathrm{d}$ subcutaneously twice daily beginning on Day 1. A) Total $\mathrm{T}_{4}$ decreased in control animals on each day of the experiment. All treated groups maintained $\mathrm{T}_{4}$ at the same level between Days 0 and 2, but decreased significantly on Day $4(\mathrm{P}<0.05)$. B) Total $\mathrm{T}_{3}$ levels decreased from Day 0 levels by Day 4 in control and $25 \mathrm{ug} / \mathrm{kg} / \mathrm{d}$ animals only $(\mathrm{P}<0.05)$. On Day 4 Total $\mathrm{T}_{3}$ levels in control animals differed from $50 \mathrm{ug} / \mathrm{kg} / \mathrm{d}$ and $100 \mathrm{ug} / \mathrm{kg} / \mathrm{d}(\mathrm{P}<0.05) .25 \mathrm{ug} / \mathrm{kg} / \mathrm{d}$ were also different from $100 \mathrm{ug} / \mathrm{kg} / \mathrm{d}$ treated groups $(\mathrm{P}<0.05)$. All groups decreased from Day 0 values by Day 4. 
Figure 5

Insulin and glucose levels during 4 days of food removal in controls or wethers receiving IGF-1 at $25 \mathrm{ug} / \mathrm{kg} / \mathrm{d}, 50 \mathrm{ug} / \mathrm{kg} / \mathrm{d}$, or $100 \mathrm{ug} / \mathrm{kg} / \mathrm{d}$ subcutaneously twice daily beginning on Day 1. A) Insulin levels decreased to undetectable levels in all groups by Day 2 $(\mathrm{P}<0.001)$. B) Glucose levels maintained in control animals throughout the experimental period and decreased by for day0 values on Day 4 in all IGF-1 treated groups $(\mathrm{P}<0.05)$. 


\section{Reference List}

1. Advis JP, Kuljis RO, Dey G 1985 Distribution of luteinizing hormone-releasing hormone (LHRH) content and total LHRH-degrading activity (LHRH-DA) in the hypothalamus of the ewe. Endocrinology 116:2410-2418

2. Jansen HT, Lubbers LS, Macchia E, DeGroot LJ, Lehman MN 1997 Thyroid hormone receptor (alpha) distribution in hamster and sheep brain: colocalization in gonadotropin-releasing hormone and other identified neurons. Endocrinology 138:5039-5047

3. Jansen HT, Hileman SM, Lubbers LS, Kuehl DE, Jackson GL, Lehman MN 1997 Identification and distribution of neuroendocrine gonadotropin-releasing hormone neurons in the ewe. Biol Reprod 56:655-662

4. Lehman MN, Robinson JE, Karsch FJ, Silverman AJ 1986 Immunocytochemical localization of luteinizing hormone-releasing hormone (LHRH) pathways in the sheep brain during anestrus and the mid-luteal phase of the estrous cycle. J Comp Neurol 244:19-35

5. Silverman AJ, Jhamandas J, Renaud LP 1987 Localization of luteinizing hormone-releasing hormone (LHRH) neurons that project to the median eminence. J Neurosci 7:2312-2319

6. Caldani M, Batailler M, Thiery JC, Dubois MP 1988 LHRH-immunoreactive structures in the sheep brain. Histochemistry 89:129-139

7. Dees WL, Sorensen AM, Jr., Kemp WM, McArthur NH 1981 Immunohistochemical localization of gonadotropin-releasing hormone $(\mathrm{GnRH})$ in the brain and infundibulum of the sheep. Cell Tissue Res 215:181-191

8. Polkowska J, Dubois MP, Domanski E 1980 Immunocytochemistry of luteinizing hormone releasing hormone (LHRH) in the sheep hypothalamus during variuos reproductive stages: correlation with the gonadotropic hormones of the pituitary. Cell Tissue Res 208:327-341

9. Blache D, Chagas LM, Blackberry MA, Vercoe PE, Martin GB 2000 Metabolic factors affecting the reproductive axis in male sheep. $\mathrm{J}$ Reprod Fertil 120:1-11

10. Clarke IJ, Cummins JT 1982 The temporal relationship between gonadotropin releasing hormone $(\mathrm{GnRH})$ and luteinizing hormone $(\mathrm{LH})$ secretion in ovariectomized ewes. Endocrinology 111:1737-1739

11. Hafez ESE 1952 Studies on the breeding season and of reproduction in the ewe. J Agric Sci 42:189-265 
12. Yeates NTM 1949 The breeding season of the sheep with particular reference to its modification by artificial means using light. J Agric Sci 39:1-43

13. Legan SJ, Karsch FJ, Foster DL 1977 The endocrine control of seasonal reproductive function in the ewe: a marked change in response to the negative feedback action of estradiol on luteinizing hormone secretion. Endocrinology 101:818-824

14. Legan SJ, Karsch FJ 1980 Photoperiodic control of seasonal breeding in ewes: modulation of the negative feedback action of estradiol. Biol Reprod 23:10611068

15. Lincoln GA 1976 Seasonal variation in the episodic secretion of luteinizing hormone and testosterone in the ram. J Endocrinol 69:213-226

16. Lincoln GA 1976 Secretion of LH in rams exposed to two different photoperiods. J Reprod Fertil 47:351-353

17. Lincoln GA 1984 Central effects of photoperiod on reproduction in the ram revealed by the use of a testosterone clamp. J Endocrinol 103:233-241

18. Barrell GK, Moenter SM, Caraty A, Karsch FJ 1992 Seasonal changes of gonadotropin-releasing hormone secretion in the ewe. Biol Reprod 46:1130-1135

19. Baird DT, Scaramuzzi RJ 1976 Changes in the secretion of ovarian steroid and pituitary luteinizing hormone in the peri-ovulatory period in the ewe: the effect of progesterone. J Endocrinol 70:237-245

20. Karsch FJ, Legan SJ, Hauger RL, Foster DL 1977 Negative feedback action of progesterone on tonic luteinizing hormone secretion in the ewe: dependence on the ovaries. Endocrinology 101:800-806

21. Goodman RL, Legan SJ, Ryan KD, Foster DL, Karsch FJ 1980 Two effects of estradiol that normally contribute to the control of tonic LH secretion in the ewe. Biol Reprod 23:415-422

22. Karsch FJ, Foster DL, Bittman EL, Goodman RL 1983 A role for estradiol in enhancing luteinizing hormone pulse frequency during the follicular phase of the estrous cycle of sheep. Endocrinology 113:1333-1339

23. Goodman RL, Bittman EL, Foster DL, Karsch FJ 1982 Alterations in the control of luteinizing hormone pulse frequency underlie the seasonal variation in estradiol negative feedback in the ewe. Biol Reprod 27:580-589

24. Scaramuzzi RJ, Tillson SA, Thorneycroft IH, Caldwell BV 1971 Action of exogenous progesterone and estrogen on behavioral estrus and luteinizing hormone levels in the ovariectomized ewe. Endocrinology 88:1184-1189 
25. Karsch FJ, Dahl GE, Evans NP, Manning JM, Mayfield KP, Moenter SM, Foster DL 1993 Seasonal changes in gonadotropin-releasing hormone secretion in the ewe: alteration in response to the negative feedback action of estradiol. Biol Reprod 49:1377-1383

26. Lincoln GA 2002 Neuroendocrine regulation of seasonal gonadotrophin and prolactin rhythms: lessons from the Soay ram model. Reprod Suppl 59:131-147

27. Rhim TJ, Kuehl D, Jackson GL 1993 Seasonal changes in the relationships between secretion of gonadotropin-releasing hormone, luteinizing hormone, and testosterone in the ram. Biol Reprod 48:197-204

28. Schanbacher BD, Ford JJ 1976 Seasonal profiles of plasma luteinizing hormone, testosterone and estradiol in the ram. Endocrinology 99:752-757

29. Lubbers LS, Jackson GL 1993 Neuroendocrine mechanisms that control seasonal changes of luteinizing hormone secretion in sheep are sexually differentiated. Biol Reprod 49:1369-1376

30. Gettys TW, D'Occhio MJ, Henricks DM, Schanbacher BD 1984 Suppression of LH secretion by oestradiol, dihydrotestosterone and trenbolone acetate in the acutely castrated bull. J Endocrinol 100:107-112

31. Bolt DJ 1971 Changes in the concentration of luteinizing hormone in plasma of rams following administration of oestradiol, progesterone or testosterone. J Reprod Fertil 24:435-438

32. Karsch FJ, Foster DL 1975 Sexual differentiation of the mechanism controlling the preovulatory discharge of luteinizing hormone in sheep. Endocrinology 97:373-379

33. Schanbacher BD 1984 Regulation of luteinizing hormone secretion in male sheep by endogenous estrogen. Endocrinology 115:944-950

34. D'Occhio MJ, Schanbacher BD, Kinder JE 1983 Androgenic and oestrogenic steroid participation in feedback control of luteinizing hormone secretion in male sheep. Acta Endocrinol (Copenh) 102:499-504

35. Hileman SM, Lubbers LS, Kuehl DE, Schaeffer DJ, Rhodes L, Jackson GL 1994 Effect of inhibiting 5 alpha-reductase activity on the ability of testosterone to inhibit luteinizing hormone release in male sheep. Biol Reprod 50:1244-1250

36. Martini L 1982 The 5alpha-reduction of testosterone in the neuroendocrine structures. Biochemical and physiological implications. Endocr Rev 3:1-25

37. Kniewald Z, Kniewald J 1981 Mode of androgen action at male and female calf pituitary level. J Steroid Biochem 15:433-437 
38. Karsch FJ, Bittman EL, Foster DL, Goodman RL, Legan SJ, Robinson JE 1984 Neuroendocrine basis of seasonal reproduction. Recent Prog Horm Res 40:185-232

39. Caraty A, Locatelli A 1988 Effect of time after castration on secretion of LHRH and LH in the ram. J Reprod Fertil 82:263-269

40. Jackson GL, Kuehl D, Rhim TJ 1991 Testosterone inhibits gonadotropinreleasing hormone pulse frequency in the male sheep. Biol Reprod 45:188-194

41. Hileman SM, Jackson GL 1999 Regulation of gonadotrophin-releasing hormone secretion by testosterone in male sheep. J Reprod Fertil Suppl 54:231-242

42. Blache D, Batailler M, Fabre-Nys C 1994 Oestrogen receptors in the preopticohypothalamic continuum: immunohistochemical study of the distribution and cell density during induced oestrous cycle in ovariectomized ewe. J Neuroendocrinol 6:329-339

43. Herbison AE, Robinson JE, Skinner DC 1993 Distribution of estrogen receptor-immunoreactive cells in the preoptic area of the ewe: co-localization with glutamic acid decarboxylase but not luteinizing hormone-releasing hormone. Neuroendocrinology 57:751-759

44. Lehman MN, Ebling FJ, Moenter SM, Karsch FJ 1993 Distribution of estrogen receptor-immunoreactive cells in the sheep brain. Endocrinology 133:876-886

45. Herbison AE 1995 Neurochemical identity of neurones expressing oestrogen and androgen receptors in sheep hypothalamus. J Reprod Fertil Suppl 49:271-283

46. Clarke IJ, Burman K, Funder JW, Findlay JK 1981 Estrogen receptors in the neuroendocrine tissues of the ewe in relation to breed, season, and stage of the estrous cycle. Biol Reprod 24:323-331

47. Mathieson RA, Kitts WD 1980 Binding of phyto-oestrogen and oestradiol-17 beta by cytoplasmic receptors in the pituitary gland and hypothalamus of the ewe. J Endocrinol 85:317-325

48. Tang BY, Adams NR 1978 Changes in oestradiol-17beta binding in the hypothalami and pituitary glands of persistently infertile ewes previously exposed to oestrogenic subterranean clover: evidence of alterations to oestradiol receptors. J Endocrinol 78:171-177

49. Scott CJ, Tilbrook AJ, Simmons DM, Rawson JA, Chu S, Fuller PJ, Ing NH, Clarke IJ 2000 The distribution of cells containing estrogen receptor-alpha (ERalpha) and ERbeta messenger ribonucleic acid in the preoptic area and hypothalamus of the sheep: comparison of males and females. Endocrinology $141: 2951-2962$ 
50. Shughrue PJ, Bushnell CD, Dorsa DM 1992 Estrogen receptor messenger ribonucleic acid in female rat brain during the estrous cycle: a comparison with ovariectomized females and intact males. Endocrinology 131:381-388

51. Hileman SM, Handa RJ, Jackson GL 1999 Distribution of estrogen receptorbeta messenger ribonucleic acid in the male sheep hypothalamus. Biol Reprod 60:1279-1284

52. Shupnik MA 2002 Oestrogen receptors, receptor variants and oestrogen actions in the hypothalamic-pituitary axis. J Neuroendocrinol 14:85-94

53. Menard CS, Harlan RE 1993 Up-regulation of androgen receptor immunoreactivity in the rat brain by androgenic-anabolic steroids. Brain Res $622: 226-236$

54. Herbison AE, Theodosis DT 1992 Localization of oestrogen receptors in preoptic neurons containing neurotensin but not tyrosine hydroxylase, cholecystokinin or luteinizing hormone-releasing hormone in the male and female rat. Neuroscience 50:283-298

55. Shivers BD, Harlan RE, Morrell JI, Pfaff DW 1983 Absence of oestradiol concentration in cell nuclei of LHRH-immunoreactive neurones. Nature 304:345347

56. Lehman MN, Karsch FJ 1993 Do gonadotropin-releasing hormone, tyrosine hydroxylase-, and beta-endorphin-immunoreactive neurons contain estrogen receptors? A double-label immunocytochemical study in the Suffolk ewe. Endocrinology 133:887-895

57. Huang X, Harlan RE 1993 Absence of androgen receptors in LHRH immunoreactive neurons. Brain Res 624:309-311

58. Robinson JE, Radford HM, Karsch FJ 1985 Seasonal changes in pulsatile luteinizing hormone (LH) secretion in the ewe: relationship of frequency of $\mathrm{LH}$ pulses to day length and response to estradiol negative feedback. Biol Reprod $33: 324-334$

59. Pelletier J, Ortavant R 1975 Photoperiodic control of LH release in the ram. II. Light-androgens interaction. Acta Endocrinol (Copenh) 78:442-450

60. Meikle LM, Fisher MW 1996 Regulation of reproductive seasonality in the red deer hind: oestradiol-dependent and -independent influences on the patterns of LH concentrations. J Reprod Fertil 106:213-220

61. Davis GJ, Meyer RK 1973 FSH and LH in the snowshoe hare during the increasing phase of the 10-year cycle. Gen Comp Endocrinol 20:53-60 
62. Anderson GM, Connors JM, Hardy SL, Valent M, Goodman RL 2002 Thyroid hormones mediate steroid-independent seasonal changes in luteinizing hormone pulsatility in the ewe. Biol Reprod 66:701-706

63. Lincoln GA, Clarke IJ 1994 Photoperiodically-induced cycles in the secretion of prolactin in hypothalamo-pituitary disconnected rams: evidence for translation of the melatonin signal in the pituitary gland. J Neuroendocrinol 6:251-260

64. Clarke IJ, Scott CJ, Rao A, Pompolo S, Barker-Gibb ML 2000 Seasonal changes in the expression of neuropeptide $Y$ and pro-opiomelanocortin mRNA in the arcuate nucleus of the ovariectomized ewe: relationship to the seasonal appetite and breeding cycles. J Neuroendocrinol 12:1105-1111

65. Lincoln GA, Rhind SM, Pompolo S, Clarke IJ 2001 Hypothalamic control of photoperiod-induced cycles in food intake, body weight, and metabolic hormones in rams. Am J Physiol Regul Integr Comp Physiol 281:R76-R90

66. Mercer JG, Moar KM, Ross AW, Hoggard N, Morgan PJ 2000 Photoperiod regulates arcuate nucleus POMC, AGRP, and leptin receptor mRNA in Siberian hamster hypothalamus. Am J Physiol Regul Integr Comp Physiol 278:R271-R281

67. Barker-Gibb ML, Scott CJ, Boublik JH, Clarke IJ 1995 The role of neuropeptide Y (NPY) in the control of LH secretion in the ewe with respect to season, NPY receptor subtype and the site of action in the hypothalamus. J Endocrinol 147:565-579

68. Hileman SM, Kuehl DE, Jackson GL 1998 Photoperiod affects the ability of testosterone to alter proopiomelanocortin mRNA, but not luteinizing hormonereleasing hormone mRNA, levels in male sheep. J Neuroendocrinol 10:587-592

69. Clarke IJ, Tilbrook AJ, Turner AI, Doughton BW, Goding JW 2001 Sex, fat and the tilt of the earth: effects of sex and season on the feeding response to centrally administered leptin in sheep. Endocrinology 142:2725-2728

70. Gentry RT, Wade GN 1976 Androgenic control of food intake and body weight in male rats. J Comp Physiol Psychol 90:18-25

71. Wade GN 1975 Some effects of ovarian hormones on food intake and body weight in female rats. J Comp Physiol Psychol 88:183-193

72. Slusser WN, Wade GN 1981 Testicular effects on food intake, body weight, and body composition in male hamsters. Physiol Behav 27:637-640

73. Blank JL, Korytko AI, Freeman DA, Ruf TP 1994 Role of gonadal steroids and inhibitory photoperiod in regulating body weight and food intake in deer mice (Peromyscus maniculatus). Proc Soc Exp Biol Med 206:396-403 
74. Chai JK, Blaha V, Meguid MM, Laviano A, Yang ZJ, Varma M 1999 Use of orchiectomy and testosterone replacement to explore meal number-to-meal size relationship in male rats. Am J Physiol 276:R1366-R1373

75. Czaja JA 1984 Sex differences in the activational effects of gonadal hormones on food intake and body weight. Physiol Behav 33:553-558

76. Kemnitz JW, Sladky KK, Flitsch TJ, Pomerantz SM, Goy RW 1988 Androgenic influences on body size and composition of adult rhesus monkeys. Am J Physiol 255:E857-E864

77. Lobley GE, Connell A, Buchan V, Skene PA, Fletcher JM 1987 Administration of testosterone to wether lambs: effects on protein and energy metabolism and growth hormone status. J Endocrinol 115:439-445

78. Madrid JA, Lopez-Bote C, Martin E 1993 Effect of neonatal androgenization on the circadian rhythm of feeding behavior in rats. Physiol Behav 53:329-335

79. Mauer MM, Bartness TJ 1995 A role for testosterone in the maintenance of seasonally appropriate body mass but not in lipectomy-induced body fat compensation in Siberian hamsters. Obes Res 3:31-41

80. Nunez AA, Grundman M 1982 Testosterone affects food intake and body weight of weanling male rats. Pharmacol Biochem Behav 16:933-936

81. Richard D, Picard F, Lemieux C, Lalonde J, Samson P, Deshaies Y 2002 The effects of topiramate and sex hormones on energy balance of male and female rats. Int J Obes Relat Metab Disord 26:344-353

82. Shimizu H, Ohtani KI, Uehara Y, Abe Y, Takahashi H, Tsuchiya T, Sato N, Ibuki Y, Mori M 1998 Orchiectomy and response to testosterone in the development of obesity in young Otsuka-Long-Evans-Tokushima Fatty (OLETF) rats. Int J Obes Relat Metab Disord 22:318-324

83. Mystkowski P, Schwartz MW 2000 Gonadal steroids and energy homeostasis in the leptin era. Nutrition 16:937-946

84. Gray JM, Nunez AA, Siegel LI, Wade GN 1979 Effects of testosterone on body weight and adipose tissue: role of aromatization. Physiol Behav 23:465-469

85. Dudley SD, Gentry RT, Silverman BS, Wade GN 1979 Estradiol and insulin: independent effects on eating and body weight in rats. Physiol Behav 22:63-67

86. Gavin ML, Gray JM, Johnson PR 1984 Estrogen-induced effects on food intake and body weight in ovariectomized, partially lipectomized rats. Physiol Behav 32:55-59 
87. Thomas DK, Storlien LH, Bellingham WP, Gillette K 1986 Ovarian hormone effects on activity, glucoregulation and thyroid hormones in the rat. Physiol Behav 36:567-573

88. Wade GN, Gray JM 1979 Gonadal effects on food intake and adiposity: a metabolic hypothesis. Physiol Behav 22:583-593

89. Heymsfield SB, Gallagher D, Poehlman ET, Wolper C, Nonas K, Nelson D, Wang ZM 1994 Menopausal changes in body composition and energy expenditure. Exp Gerontol 29:377-389

90. Geary N 2001 Estradiol, CCK and satiation. Peptides 22:1251-1263

91. Baskin DG, Norwood BJ, Schwartz MW, Koerker DJ 1995 Estradiol inhibits the increase of hypothalamic neuropeptide $\mathrm{Y}$ messenger ribonucleic acid expression induced by weight loss in ovariectomized rats. Endocrinology $136: 5547-5554$

92. Bonavera JJ, Dube MG, Kalra PS, Kalra SP 1994 Anorectic effects of estrogen may be mediated by decreased neuropeptide-Y release in the hypothalamic paraventricular nucleus. Endocrinology 134:2367-2370

93. Sahu A, Crowley WR, Kalra PS, Kalra SP 1992 A selective sexually dimorphic response in the median eminence neuropeptide Y. Brain Res 573:235-242

94. Shimizu H, Ohtani K, Kato Y, Tanaka Y, Mori M 1996 Withdrawal of [corrected] estrogen increases hypothalamic neuropeptide Y (NPY) mRNA expression in ovariectomized obese rat. Neurosci Lett 204:81-84

95. Gomez F, Dallman MF 2001 Manipulation of androgens causes different energetic responses to cold in 60- and 40-day-old male rats. Am J Physiol Regul Integr Comp Physiol 280:R262-R273

96. Earley CJ, Leonard BE 1979 Androgens, estrogens and their anti-hormones: effects on body weight and food consumption. Pharmacol Biochem Behav $11: 211-214$

97. Pinilla L, Seoane LM, Gonzalez L, Carro E, Aguilar E, Casanueva FF, Dieguez C 1999 Regulation of serum leptin levels by gonadal function in rats. Eur J Endocrinol 140:468-473

98. Huffman LJ, Inskeep EK, Goodman RL 1987 Changes in episodic luteinizing hormone secretion leading to puberty in the lamb. Biol Reprod 37:755-761

99. Olster DH, Foster DL 1986 Control of gonadotropin secretion in the male during puberty: a decrease in response to steroid inhibitory feedback in the absence of an increase in steroid-independent drive in the sheep. Endocrinology 118:2225-2234 
100. Claypool LE, Foster DL 1990 Sexual differentiation of the mechanism controlling pulsatile secretion of luteinizing hormone contributes to sexual differences in the timing of puberty in sheep. Endocrinology 126:1206-1215

101. Foster DL, Yellon SM 1987 Absence of an increase in gonad-independent drive to pulsatile luteinizing hormone secretion during photoperiod-induced puberty. Biol Reprod 37:634-639

102. Foster DL, Olster DH 1985 Effect of restricted nutrition on puberty in the lamb: patterns of tonic luteinizing hormone (LH) secretion and competency of the LH surge system. Endocrinology 116:375-381

103. Wood RI, Ebling FJ, I'Anson H, Foster DL 1991 The timing of neuroendocrine sexual maturity in the male lamb by photoperiod. Biol Reprod 45:82-88

104. Howles CM, Webster GM, Haynes NB 1980 The effect of rearing under a long or short photoperiod on testis growth, plasma testosterone and prolactin concentrations, and the development of sexual behaviour in rams. J Reprod Fertil $60: 437-447$

105. Ojeda SR, Urbanski HF, Ahmed CE 1986 The onset of female puberty: studies in the rat. Recent Prog Horm Res 42:385-442

106. Claypool LE, Watanabe G, Terasawa E 1990 Effects of electrical stimulation of the medial basal hypothalamus on the in vivo release of luteinizing hormonereleasing hormone in the prepubertal and peripubertal female monkey. Endocrinology 127:3014-3022

107. Plant TM, Gay VL, Marshall GR, Arslan M 1989 Puberty in monkeys is triggered by chemical stimulation of the hypothalamus. Proc Natl Acad Sci U S A $86: 2506-2510$

108. Plant TM 1986 A striking sex difference in the gonadotropin response to gonadectomy during infantile development in the rhesus monkey (Macaca mulatta). Endocrinology 119:539-545

109. Chongthammakun S, Claypool LE, Terasawa E 1993 Ovariectomy increases in vivo luteinizing hormone-releasing hormone release in pubertal, but not prepubertal, female rhesus monkeys. J Neuroendocrinol 5:41-50

110. Plant TM 1985 A study of the role of the postnatal testes in determining the ontogeny of gonadotropin secretion in the male rhesus monkey (Macaca mulatta). Endocrinology 116:1341-1350

111. Richter TA, Terasawa E 2001 Neural mechanisms underlying the pubertal increase in LHRH release in the rhesus monkey. Trends Endocrinol Metab $12: 353-359$ 
112. Plant TM 2001 Leptin, growth hormone, and the onset of primate puberty. J Clin Endocrinol Metab 86:458-460

113. Foster DL, Nagatani S 1999 Physiological perspectives on leptin as a regulator of reproduction: role in timing puberty. Biol Reprod 60:205-215

114. Kennedy GC, Mirta J 1963 Body weight and food intake as initiating factors for puberty in the rat. J Physiol 166:408-418

115. McShane TM, May T, Miner JL, Keisler DH 1992 Central actions of neuropeptide-Y may provide a neuromodulatory link between nutrition and reproduction. Biol Reprod 46:1151-1157

116. I'Anson H, Manning JM, Herbosa CG, Pelt J, Friedman CR, Wood RI, Bucholtz DC, Foster DL 2000 Central inhibition of gonadotropin-releasing hormone secretion in the growth-restricted hypogonadotropic female sheep. Endocrinology 141:520-527

117. I'Anson H, Herbosa CG, Ebling FJ, Wood RI, Bucholtz DC, Mieher CD, Foster DL, Padmanabhan V 1993 Hypothalamic versus pituitary stimulation of luteinizing hormone secretion in the prepubertal female lamb.

Neuroendocrinology 57:467-475

118. Bronson FH 1986 Food-restricted, prepubertal, female rats: rapid recovery of luteinizing hormone pulsing with excess food, and full recovery of pubertal development with gonadotropin-releasing hormone. Endocrinology 118:24832487

119. Yavas Y, Walton JS 2000 Postpartum acyclicity in suckled beef cows: a review. Theriogenology 54:25-55

120. Beam SW, Butler WR 1997 Energy balance and ovarian follicle development prior to the first ovulation postpartum in dairy cows receiving three levels of dietary fat. Biol Reprod 56:133-142

121. Mandiki SMN, Bister JL, Paguay R 1990 Effects of suckling node on endocrine control of reproductive activity resumption in Texel ewes lambing in July or November. Theriogenology 33:397-413

122. Schillo KK 1992 Effects of dietary energy on control of luteinizing hormone secretion in cattle and sheep. J Anim Sci 70:1271-1282

123. Lalman DL, Williams JE, Hess BW, Thomas MG, Keisler DH 2000 Effect of dietary energy on milk production and metabolic hormones in thin, primiparous beef heifers. J Anim Sci 78:530-538 
124. Hightshoe RB, Cochran RC, Corah LR, Kiracofe GH, Harmon DL, Perry RC 1991 Effects of calcium soaps of fatty acids on postpartum reproductive function in beef cows. J Anim Sci 69:4097-4103

125. Ryan DP, Spoon RA, Griffith MK, Williams GL 1994 Ovarian follicular recruitment, granulosa cell steroidogenic potential and growth hormone/insulinlike growth factor-I relationships in suckled beef cows consuming high lipid diets: effects of graded differences in body condition maintained during the puerperium. Domest Anim Endocrinol 11:161-174

126. Connor HC, Houghton PL, Lemenager RP, Malven PV, Parfet JR, Moss GE 1990 Effect of dietary energy, body condition and calf removal on pituitary gonadotropins, gonadotropin-releasing hormone $(\mathrm{GnRH})$ and hypothalamic opioids in beef cows. Domest Anim Endocrinol 7:403-411

127. Lishman AW, Stielau WJ, Dreosti IE, Botha WA, Stewart AM, Swart CE 1974 The release of LH at oestrus in ewes on two planes of nutrition during lactation. J Reprod Fertil 41:227-230

128. Nakanishi Y, Mori J, Nagasawa H 1976 Recovery of pituitary secretion of gonadotrophins and prolactin during re-feeding after chronic restricted feeding in female rats. J Endocrinol 69:329-339

129. Temple JL, Rissman EF 2000 Brief refeeding restores reproductive readiness in food-restricted female musk shrews (Suncus murinus). Horm Behav 38:21-28

130. Tropp J, Markus EJ 2001 Effects of mild food deprivation on the estrous cycle of rats. Physiol Behav 73:553-559

131. Rhodes FM, Entwistle KW, Kinder JE 1996 Changes in ovarian function and gonadotropin secretion preceding the onset of nutritionally induced anestrus in Bos indicus heifers. Biol Reprod 55:1437-1443

132. Richards MW, Wettemann RP, Schoenemann HM 1989 Nutritional anestrus in beef cows: body weight change, body condition, luteinizing hormone in serum and ovarian activity. J Anim Sci 67:1520-1526

133. Bossis I, Wettemann RP, Welty SD, Vizcarra JA, Spicer LJ, Diskin MG 1999 Nutritionally induced anovulation in beef heifers: ovarian and endocrine function preceding cessation of ovulation. J Anim Sci 77:1536-1546

134. Haresign W 1981 The influence of nutrition on reproduction in the ewe: effects on ovulation role, follicle development and luteinizing hormone release. Anim Prod 32:197-202

135. McNeilly AS, Jonassen JA, Rhind SM 1987 Reduced ovarian follicular development as a consequence of low body condition in ewes. Acta Endocrinol (Copenh) 115:75-83 
136. Tatman WR, Judkins MB, Dunn TG, Moss GE 1990 Luteinizing hormone in nutrient-restricted ovariectomized ewes. J Anim Sci 68:1097-1102

137. Gunn RG, Doney JM 1975 The interaction of nutrition and body condition at mating on ovulation rate and on early embryo mortality in Scottish Blackface ewes. J Agric Sci 85:465-470

138. Gunn RG, Doney JM 1979 Fertility in Cheviot ewes. Anim Prod 29:11-16

139. Bronson FH 1989 Mammalian Reproductive Biology.University of Chicago Press,

140. Lopez FJ, Negro-Vilar A 1990 Galanin stimulates luteinizing hormone-releasing hormone secretion from arcuate nucleus-median eminence fragments in vitro: involvement of an alpha-adrenergic mechanism. Endocrinology 127:2431-2436

141. Lopez FJ, Merchenthaler I, Liposits Z, Negro-Vilar A 1996 Steroid imprinting and modulation of sexual dimorphism in the luteinizing hormone-releasing hormone neuronal system. Cell Mol Neurobiol 16:129-141

142. Vitale ML, Parisi MN, Chiocchio SR, Tramezzani JH 1986 Serotonin induces gonadotrophin release through stimulation of LH-releasing hormone release from the median eminence. J Endocrinol 111:309-315

143. Brann DW, Mahesh VB 1995 Glutamate: a major neuroendocrine excitatory signal mediating steroid effects on gonadotropin secretion. J Steroid Biochem Mol Biol 53:325-329

144. Robinson JE 1995 Gamma amino-butyric acid and the control of GnRH secretion in sheep. J Reprod Fertil Suppl 49:221-230

145. Ma YJ, Berg-von der EK, Rage F, Wetsel WC, Ojeda SR 1997 Hypothalamic astrocytes respond to transforming growth factor-alpha with the secretion of neuroactive substances that stimulate the release of luteinizing hormone-releasing hormone. Endocrinology 138:19-25

146. Bauer-Dantoin AC, Knox KL, Schwartz NB, Levine JE 1993 Estrous cycle stage-dependent effects of neuropeptide-Y on luteinizing hormone (LH)-releasing hormone-stimulated LH and follicle-stimulating hormone secretion from anterior pituitary fragments in vitro. Endocrinology 133:2413-2417

147. Malven PV, Haglof SA, Degroot H 1992 Effects of intracerebral administration of neuropeptide-Y on secretion of luteinizing hormone in ovariectomized sheep. Brain Res Bull 28:871-875

148. Woller MJ, Terasawa E 1991 Infusion of neuropeptide $Y$ into the stalk-median eminence stimulates in vivo release of luteinizing hormone-release hormone in gonadectomized rhesus monkeys. Endocrinology 128:1144-1150 
149. Tillet Y, Caldani M, Batailler M 1989 Anatomical relationships of monoaminergic and neuropeptide $\mathrm{Y}$-containing fibres with luteinizing hormonereleasing hormone systems in the preoptic area of the sheep brain: immunohistochemical studies. J Chem Neuroanat 2:319-326

150. Sar M, Sahu A, Crowley WR, Kalra SP 1990 Localization of neuropeptide-Y immunoreactivity in estradiol-concentrating cells in the hypothalamus. Endocrinology 127:2752-2756

151. Ahima RS, Saper CB, Flier JS, Elmquist JK 2000 Leptin regulation of neuroendocrine systems. Front Neuroendocrinol 21:263-307

152. Hoyenga KB, Hoyenga KT 1982 Gender and energy balance: sex differences in adaptations for feast and famine. Physiol Behav 28:545-563

153. Widdowson EM 1976 The response of the sexes to nutritional stress. Proc Nutr Soc 35:175-180

154. Nichols A, Llanza N, McManus CJ, Lubbers LS, Hileman SM, Sexual dimorphism in the response to a high fat diet in C57B1/6J mice. (Abstract)

155. Harris RB, Bowen HM, Mitchell TD 2003 Leptin resistance in mice is determined by gender and duration of exposure to high-fat diet. Physiol Behav 78:543-555

156. Landt M, Gingerich RL, Havel PJ, Mueller WM, Schoner B, Hale JE, Heiman ML 1998 Radioimmunoassay of rat leptin: sexual dimorphism reversed from humans. Clin Chem 44:565-570

157. Ahren B 2000 Diurnal variation in circulating leptin is dependent on gender, food intake and circulating insulin in mice. Acta Physiol Scand 169:325-331

158. Rosenbaum M, Leibel RL 1999 Clinical review 107: Role of gonadal steroids in the sexual dimorphisms in body composition and circulating concentrations of leptin. J Clin Endocrinol Metab 84:1784-1789

159. Hileman SM, Pierroz DD, Dushay J, Ahima RS, Llanza N, Lubbers LS, Flier JS, Sex-dependent response of leptin to fasting in mice. (Abstract)

160. Ahima RS, Prabakaran D, Mantzoros C, Qu D, Lowell B, Maratos-Flier E, Flier JS 1996 Role of leptin in the neuroendocrine response to fasting. Nature $382: 250-252$

161. Wu SY, Wright C, Parker LN, Florsheim W 1990 Induction of type II T4-5'monodeiodinase activity in brown adipose tissue in fasted mice. Am J Med Sci 299:21-25 
162. Bale TL, Contarino A, Smith GW, Chan R, Gold LH, Sawchenko PE, Koob GF, Vale WW, Lee KF 2000 Mice deficient for corticotropin-releasing hormone receptor-2 display anxiety-like behaviour and are hypersensitive to stress. Nat Genet 24:410-414

163. Born J, Ditschuneit I, Schreiber M, Dodt C, Fehm HL 1995 Effects of age and gender on pituitary-adrenocortical responsiveness in humans. Eur J Endocrinol 132:705-711

164. Davis SN, Cherrington AD, Goldstein RE, Jacobs J, Price L 1993 Effects of insulin on the counterregulatory response to equivalent hypoglycemia in normal females. Am J Physiol 265:E680-E689

165. Fanelli C, Pampanelli S, Epifano L, Rambotti AM, Ciofetta M, Modarelli F, Di Vincenzo A, Annibale B, Lepore M, Lalli C, . 1994 Relative roles of insulin and hypoglycaemia on induction of neuroendocrine responses to, symptoms of, and deterioration of cognitive function in hypoglycaemia in male and female humans. Diabetologia 37:797-807

166. Gatford KL, Fletcher TP, Clarke IJ, Owens PC, Quinn KJ, Walton PE, Grant PA, Hosking BJ, Egan AR, Ponnampalam EN 1996 Sexual dimorphism of circulating somatotropin, insulin-like growth factor I and II, insulin-like growth factor binding proteins, and insulin: relationships to growth rate and carcass characteristics in growing lambs. J Anim Sci 74:1314-1325

167. Medrano JF, Bradford GE 1991 Growth performance and plasma insulin-like growth factor I concentrations in sheep selected for high weaning weight. J Anim Sci 69:1912-1918

168. Roberts CA, McCutcheon SN, Blair HT, Gluckman PD, Breier BH 1990 Developmental patterns of plasma insulin-like growth factor-1 concentrations in sheep. Domest Anim Endocrinol 7:457-463

169. Wood RI, Foster DL 1998 Sexual differentiation of reproductive neuroendocrine function in sheep. Rev Reprod 3:130-140

170. Frisch RE, McArthur JW 1974 Menstrual cycles: fatness as a determinant of minimum weight for height necessary for their maintenance or onset. Science 185:949-951

171. Imakawa K, Day ML, Zalesky DD, Garcia-Winder M, Kittok RJ, Kinder JE 1986 Influence of dietary-induced weight changes on serum luteinizing hormone, estrogen and progesterone in the bovine female. Biol Reprod 35:377-384

172. Randel RD 1990 Nutrition and postpartum rebreeding in cattle. J Anim Sci 68:853-862 
173. Schneider JE, Wade GN 1989 Availability of metabolic fuels controls estrous cyclicity of Syrian hamsters. Science 244:1326-1328

174. I'Anson H, Foster DL, Foxcroft GR, Booth PJ 1991 Nutrition and reproduction. Oxf Rev Reprod Biol 13:239-311

175. Nimrod A, Ryan KJ 1975 Aromatization of androgens by human abdominal and breast fat tissue. J Clin Endocrinol Metab 40:367-372

176. Bronson FH 1988 Effect of food manipulation on the GnRH-LH-estradiol axis of young female rats. Am J Physiol 254:R616-R621

177. Dubey AK, Cameron JL, Steiner RA, Plant TM 1986 Inhibition of gonadotropin secretion in castrated male rhesus monkeys (Macaca mulatta) induced by dietary restriction: analogy with the prepubertal hiatus of gonadotropin release. Endocrinology 118:518-525

178. Bronson FH, Manning JM 1991 The energetic regulation of ovulation: a realistic role for body fat. Biol Reprod 44:945-950

179. Warren MP 1980 The effects of exercise on pubertal progression and reproductive function in girls. J Clin Endocrinol Metab 51:1150-1157

180. Bronson FH 1987 Puberty in female rats: relative effect of exercise and food restriction. Am J Physiol 252:R140-R144

181. Glass AR, Dahms WT, Swerdloff RS 1979 Body fat at puberty in rats: alteration by changes in diet. Pediatr Res 13:7-9

182. Hansen PJ, Schillo KK, Hinshelwood MM, Hauser ER 1983 Body composition at vaginal opening in mice as influenced by food intake and photoperiod: tests of critical body weight and composition hypotheses for puberty onset. Biol Reprod 29:924-931

183. Perrigo G, Bronson FH 1983 Foraging effort, food intake, fat deposition and puberty in female mice. Biol Reprod 29:455-463

184. Rinderknecht E, Humbel RE 1976 Polypeptides with nonsuppressible insulinlike and cell-growth promoting activities in human serum: isolation, chemical characterization, and some biological properties of forms I and II. Proc Natl Acad Sci U S A 73:2365-2369

185. Bach MA, Bondy CA 1992 Anatomy of the pituitary insulin-like growth factor system. Endocrinology 131:2588-2594

186. Sara VR, Hall K 1990 Insulin-like growth factors and their binding proteins. Physiol Rev 70:591-614 
187. Schwander JC, Hauri C, Zapf J, Froesch ER 1983 Synthesis and secretion of insulin-like growth factor and its binding protein by the perfused rat liver: dependence on growth hormone status. Endocrinology 113:297-305

188. Cohick WS, Clemmons DR 1993 The insulin-like growth factors. Annu Rev Physiol 55:131-153

189. Funston RN, Roberts AJ, Hixon DL, Hallford DM, Sanson DW, Moss GE 1995 Effect of acute glucose antagonism on hypophyseal hormones and concentrations of insulin-like growth factor (IGF)-I and IGF-binding proteins in serum, anterior pituitary, and hypothalamus of ewes. Biol Reprod 52:1179-1186

190. Funston RN, Moss GE, Roberts AJ 1995 Insulin-like growth factor-I (IGF-I) and IGF-binding proteins in bovine sera and pituitaries at different stages of the estrous cycle. Endocrinology 136:62-68

191. Guler HP, Zapf J, Scheiwiller E, Froesch ER 1988 Recombinant human insulin-like growth factor I stimulates growth and has distinct effects on organ size in hypophysectomized rats. Proc Natl Acad Sci U S A 85:4889-4893

192. LeRoith D, Werner H, Beitner-Johnson D, Roberts CT, Jr. 1995 Molecular and cellular aspects of the insulin-like growth factor I receptor. Endocr Rev $16: 143-163$

193. Fletcher TP, Thomas GB, Dunshea FR, Moore LG, Clarke IJ 1995 IGF feedback effects on growth hormone secretion in ewes: evidence for action at the pituitary but not the hypothalamic level. J Endocrinol 144:323-331

194. Minami S, Suzuki N, Sugihara H, Tamura H, Emoto N, Wakabayashi I 1997 Microinjection of rat GH but not human IGF-I into a defined area of the hypothalamus inhibits endogenous GH secretion in rats. J Endocrinol 153:283290

195. Spencer GS, Bass JJ, Hodgkinson SC, Edgley WH, Moore LG 1991 Effect of intracerebroventricular injection of IGF-I on circulating growth hormone concentrations in the sheep. Domest Anim Endocrinol 8:155-160

196. Bhaumick B, Bala RM 1987 Receptors for insulin-like growth factors I and II in developing embryonic mouse limb bud. Biochim Biophys Acta 927:117-128

197. DeChiara TM, Efstratiadis A, Robertson EJ 1990 A growth-deficiency phenotype in heterozygous mice carrying an insulin-like growth factor II gene disrupted by targeting. Nature 345:78-80

198. DeChiara TM, Robertson EJ, Efstratiadis A 1991 Parental imprinting of the mouse insulin-like growth factor II gene. Cell 64:849-859 
199. Powell-Braxton L, Hollingshead P, Warburton C, Dowd M, Pitts-Meek S, Dalton D, Gillett N, Stewart TA 1993 IGF-I is required for normal embryonic growth in mice. Genes Dev 7:2609-2617

200. Skottner A, Clark RG, Fryklund L, Robinson IC 1989 Growth responses in a mutant dwarf rat to human growth hormone and recombinant human insulin-like growth factor I. Endocrinology 124:2519-2526

201. Stewart CE, Rotwein P 1996 Growth, differentiation, and survival: multiple physiological functions for insulin-like growth factors. Physiol Rev 76:1005-1026

202. McKnight BJ, Goddard C 1989 The effect of food restriction on circulating insulin-like growth factor-I in mice divergently selected for high or low protein or fat to body mass ratios. Comp Biochem Physiol A 92:565-569

203. Sohlstrom A, Katsman A, Kind KL, Grant PA, Owens PC, Robinson JS, Owens JA 1998 Effects of acute and chronic food restriction on the insulin-like growth factor axis in the guinea pig. J Endocrinol 157:107-114

204. Monaco MH, Donovan SM 1997 Moderate food restriction reduces serum IGF-I and alters circulating IGF-binding protein profiles in lactating rats. J Endocrinol $152: 303-316$

205. Breier BH, Bass JJ, Butler JH, Gluckman PD 1986 The somatotrophic axis in young steers: influence of nutritional status on pulsatile release of growth hormone and circulating concentrations of insulin-like growth factor 1 . J Endocrinol 111:209-215

206. Clemmons DR, Klibanski A, Underwood LE, McArthur JW, Ridgway EC, Beitins IZ, Van Wyk JJ 1981 Reduction of plasma immunoreactive somatomedin C during fasting in humans. J Clin Endocrinol Metab 53:1247-1250

207. Merimee TJ, Zapf J, Froesch ER 1982 Insulin-like growth factors in the fed and fasted states. J Clin Endocrinol Metab 55:999-1002

208. Eigenmann JE, de Bruijne JJ, Froesch ER 1985 Insulin-like growth factor I and growth hormone in canine starvation. Acta Endocrinol (Copenh) 108:161-166

209. Bornfeldt KE, Arnqvist HJ, Enberg B, Mathews LS, Norstedt G 1989 Regulation of insulin-like growth factor-I and growth hormone receptor gene expression by diabetes and nutritional state in rat tissues. J Endocrinol 122:651656

210. Straus DS, Takemoto CD 1990 Effect of fasting on insulin-like growth factor-I (IGF-I) and growth hormone receptor mRNA levels and IGF-I gene transcription in rat liver. Mol Endocrinol 4:91-100 
211. Hiney JK, Ojeda SR, Dees WL 1991 Insulin-like growth factor I: a possible metabolic signal involved in the regulation of female puberty.

Neuroendocrinology 54:420-423

212. Bourguignon JP, Gerard A, Alvarez Gonzalez ML, Franchimont P 1993 Acute suppression of gonadotropin-releasing hormone secretion by insulin-like growth factor I and subproducts: an age-dependent endocrine effect. Neuroendocrinology 58:525-530

213. Hiney JK, Srivastava V, Nyberg CL, Ojeda SR, Dees WL 1996 Insulin-like growth factor I of peripheral origin acts centrally to accelerate the initiation of female puberty. Endocrinology 137:3717-3728

214. Armstrong CS, Wuarin L, Ishii DN 2000 Uptake of circulating insulin-like growth factor-I into the cerebrospinal fluid of normal and diabetic rats and normalization of IGF-II mRNA content in diabetic rat brain. J Neurosci Res 59:649-660

215. Adam CL, Gadd TS, Findlay PA, Wathes DC 2000 IGF-I stimulation of luteinizing hormone secretion, IGF-binding proteins (IGFBPs) and expression of mRNAs for IGFs, IGF receptors and IGFBPs in the ovine pituitary gland. J Endocrinol 166:247-254

216. Homburg R 1996 Growth hormone and fertility--clinical studies. Horm Res 45:81-85

217. Spiteri-Grech J, Nieschlag E 1992 The role of growth hormone and insulin-like growth factor I in the regulation of male reproductive function. Horm Res 38 Suppl 1:22-27

218. Adam CL, Findlay PA, Moore AH 1998 Effects of insulin-like growth factor-1 on luteinizing hormone secretion in sheep. Anim Reprod Sci 50:45-56

219. Handelsman DJ, Spaliviero JA, Scott CD, Baxter RC 1987 Hormonal regulation of the peripubertal surge of insulin-like growth factor-I in the rat. Endocrinology 120:491-496

220. Copeland KC, Eichberg JW, Parker CR, Jr., Bartke A 1985 Puberty in the chimpanzee: somatomedin-C and its relationship to somatic growth and steroid hormone concentrations. J Clin Endocrinol Metab 60:1154-1160

221. Renaville R, Massart S, Sneyers M, Falaki M, Gengler N, Burny A, Portetelle D 1996 Dissociation of increases in plasma insulin-like growth factor I and testosterone during the onset of puberty in bulls. J Reprod Fertil 106:79-86

222. Simpson RB, Armstrong JD, Harvey RW, Miller DC, Heimer EP, Campbell RM 1991 Effect of active immunization against growth hormone-releasing factor on growth and onset of puberty in beef heifers. J Anim Sci 69:4914-4924 
223. Murphy LJ 1991 Estrogen induction of insulin-like growth factors and myc proto-oncogene expression in the uterus. J Steroid Biochem Mol Biol 40:223-230

224. Michels KM, Lee WH, Seltzer A, Saavedra JM, Bondy CA 1993 Upregulation of pituitary [125I]insulin-like growth factor-I (IGF-I) binding and IGF binding protein-2 and IGF-I gene expression by estrogen. Endocrinology 132:2329

225. Bassett JM, Weston RH, Hogan JP 1971 Dietary regulation of plasma insulin and growth hormone concentrations in sheep. Aust J Biol Sci 24:321-330

226. Bagdade JD, Bierman EL, Porte D, Jr. 1967 The significance of basal insulin levels in the evaluation of the insulin response to glucose in diabetic and nondiabetic subjects. J Clin Invest 46:1549-1557

227. Schwartz MW, Bergman RN, Kahn SE, Taborsky GJ, Jr., Fisher LD, Sipols AJ, Woods SC, Steil GM, Porte D, Jr. 1991 Evidence for entry of plasma insulin into cerebrospinal fluid through an intermediate compartment in dogs. Quantitative aspects and implications for transport. J Clin Invest 88:1272-1281

228. Baskin DG, Figlewicz DP, Woods SC, Porte D, Jr., Dorsa DM 1987 Insulin in the brain. Annu Rev Physiol 49:335-347

229. van Houten M, Posner BI, Kopriwa BM, Brawer JR 1980 Insulin binding sites localized to nerve terminals in rat median eminence and arcuate nucleus. Science 207:1081-1083

230. Woods SC, Lotter EC, McKay LD, Porte D, Jr. 1979 Chronic intracerebroventricular infusion of insulin reduces food intake and body weight of baboons. Nature 282:503-505

231. Woods SC, Stein LJ, McKay LD, Porte D, Jr. 1984 Suppression of food intake by intravenous nutrients and insulin in the baboon. Am J Physiol 247:R393-R401

232. Schechter R, Sadiq HF, Devaskar SU 1990 Insulin and insulin mRNA are detected in neuronal cell cultures maintained in an insulin-free/serum-free medium. J Histochem Cytochem 38:829-836

233. Boukhliq R, Adams NR, Martin GB 1996 Effect of nutrition on the balance of production of ovarian and pituitary hormones in ewes. Anim Reprod Sci 45:59-70

234. Arias P, Rodriguez M, Szwarcfarb B, Sinay IR, Moguilevsky JA 1992 Effect of insulin on LHRH release by perifused hypothalamic fragments. Neuroendocrinology 56:415-418

235. Miller DW, Blache D, Martin GB 1995 The role of intracerebral insulin in the effect of nutrition on gonadotrophin secretion in mature male sheep. J Endocrinol $147: 321-329$ 
236. Tanaka T, Nagatani S, Bucholtz DC, Ohkura S, Tsukamura H, Maeda K, Foster DL 2000 Central action of insulin regulates pulsatile luteinizing hormone secretion in the diabetic sheep model. Biol Reprod 62:1256-1261

237. Bucholtz DC, Chiesa A, Pappano WN, Nagatani S, Tsukamura H, Maeda KI, Foster DL 2000 Regulation of pulsatile luteinizing hormone secretion by insulin in the diabetic male lamb. Biol Reprod 62:1248-1255

238. Hileman SM, Schillo KK, Hall JB 1993 Effects of acute, intracerebroventricular administration of insulin on serum concentrations of luteinizing hormone, insulin, and glucose in ovariectomized lambs during restricted and ad libitum feed intake. Biol Reprod 48:117-124

239. May JV, Schomberg DW 1981 Granulosa cell differentiation in vitro: effect of insulin on growth and functional integrity. Biol Reprod 25:421-431

240. Barbieri RL, Makris A, Ryan KJ 1983 Effects of insulin on steroidogenesis in cultured porcine ovarian theca. Fertil Steril 40:237-241

241. Owen OE, Morgan AP, Kemp HG, Sullivan JM, Herrera MG, Cahill GF, Jr. 1967 Brain metabolism during fasting. J Clin Invest 46:1589-1595

242. Ritter RC, Slusser PG, Stone S 1981 Glucoreceptors controlling feeding and blood glucose: location in the hindbrain. Science 213:451-452

243. Oomura Y, Ono T, Ooyama H, Wayner MJ 1969 Glucose and osmosensitive neurones of the rat hypothalamus. Nature 222:282-284

244. Richards MW, Wettemann RP, Schoenemann HM 1989 Nutritional anestrus in beef cows: concentrations of glucose and nonesterified fatty acids in plasma and insulin in serum. J Anim Sci 67:2354-2362

245. Hileman SM, Schillo KK, Kearnan JM, Mohapatra S, Effect of restriction of metabolic fuels on LH and GH secretion in ovariectomized lambs. p 138 (Abstract)

246. Clarke IJ, Horton RJ, Doughton BW 1990 Investigation of the mechanism by which insulin-induced hypoglycemia decreases luteinizing hormone secretion in ovariectomized ewes. Endocrinology 127:1470-1476

247. Branum JC, Kline RS, Whisnant CS 1997 The effects of neurotransmitter antagonists and glucose on luteinizing hormone secretion in growth-restricted wethers. Anim Reprod Sci 45:263-272

248. McClure TJ, Nancarrow CD, Radford HM 1978 The effect of 2-deoxy-Dglucose on ovarian function of cattle. Aust J Biol Sci 31:183-186 
249. Crump AD, Lomax MA, Rodway RG 1982 Oestradiol-induced luteinizing hormone release is inhibited by 2-deoxyglucose infusion in sheep. J Physiol 330:93P-94P

250. Bucholtz DC, Vidwans NM, Herbosa CG, Schillo KK, Foster DL 1996 Metabolic interfaces between growth and reproduction. V. Pulsatile luteinizing hormone secretion is dependent on glucose availability. Endocrinology 137:601607

251. Nagatani S, Bucholtz DC, Murahashi K, Estacio MA, Tsukamura H, Foster DL, Maeda KI 1996 Reduction of glucose availability suppresses pulsatile luteinizing hormone release in female and male rats. Endocrinology 137:11661170

252. Blum JW, Gingins M, Vitins P, Bickel H 1980 Thyroid hormone levels related to energy and nitrogen balance during weight loss and regain in adult sheep. Acta Endocrinol (Copenh) 93:440-447

253. Jung RT, Shetty PS, James WP 1980 The effect of refeeding after semistarvation on catecholamine and thyroid metabolism. Int J Obes 4:95-100

254. Ortiz-Caro J, Gonzalez C, Jolin T 1984 Diurnal variations of plasma growth hormone, thyrotropin, thyroxine, and triiodothyronine in streptozotocin-diabetic and food-restricted rats. Endocrinology 115:2227-2232

255. Schreihofer DA, Parfitt DB, Cameron JL 1993 Suppression of luteinizing hormone secretion during short-term fasting in male rhesus monkeys: the role of metabolic versus stress signals. Endocrinology 132:1881-1889

256. Danforth E Jr, Horton ES, O'Connell M, Sims EA, Burger AG, Ingbar SH, Braverman L, Vagenakis AG 1979 Dietary-induced alterations in thyroid hormone metabolism during overnutrition. J Clin Invest 64:1336-1347

257. Jung RT, Shetty PS, James WP 1980 Nutritional effects on thyroid and catecholamine metabolism. Clin Sci (Lond) 58:183-191

258. Vinik AI, Kalk WJ, McLaren H, Hendricks S, Pimstone BL 1975 Fasting blunts the TSH response to synthetic thyrotropin-releasing hormone (TRH). J Clin Endocrinol Metab 40:509-511

259. Danforth E Jr, Burger AG 1989 The impact of nutrition on thyroid hormone physiology and action. Annu Rev Nutr 9:201-227

260. Goldsmith AR, Nicholls TJ 1984 Thyroidectomy prevents the development of photorefractoriness and the associated rise in plasma prolactin in starlings. Gen Comp Endocrinol 54:256-263 
261. Woitkewitsch AA 1940 Dependence of seasonal periodicity in gonadal changes on the thyroid gland in Sturnus vulgaris. C R (Doklady) Acad Sci URSS 27:741745

262. Jallageas M, Assenmacher I 1979 Further evidence for reciprocal interactions between the annual sexual and thyroid cycles in male Peking ducks. Gen Comp Endocrinol 37:44-51

263. Nicholls TJ, Follett BK, Goldsmith AR, Pearson H 1988 Possible homologies between photorefractoriness in sheep and birds: the effect of thyroidectomy on the length of the ewe's breeding season. Reprod Nutr Dev 28:375-385

264. Follett BK, Potts C 1990 Hypothyroidism affects reproductive refractoriness and the seasonal oestrous period in Welsh Mountain ewes. J Endocrinol 127:103-109

265. Moenter SM, Woodfill CJ, Karsch FJ 1991 Role of the thyroid gland in seasonal reproduction: thyroidectomy blocks seasonal suppression of reproductive neuroendocrine activity in ewes. Endocrinology 128:1337-1344

266. Webster JR, Moenter SM, Barrell GK, Lehman MN, Karsch FJ 1991 Role of the thyroid gland in seasonal reproduction. III. Thyroidectomy blocks seasonal suppression of gonadotropin-releasing hormone secretion in sheep. Endocrinology 129:1635-1643

267. Webster JR, Moenter SM, Woodfill CJ, Karsch FJ 1991 Role of the thyroid gland in seasonal reproduction. II. Thyroxine allows a season-specific suppression of gonadotropin secretion in sheep. Endocrinology 129:176-183

268. Goldsmith AR, Nicholls TJ, Plowman G 1985 Thyroxine treatment facilitates prolactin secretion and induces a state of photorefractoriness in thyroidectomized starlings. J Endocrinol 104:99-103

269. Viguie C, Battaglia DF, Krasa HB, Thrun LA, Karsch FJ 1999 Thyroid hormones act primarily within the brain to promote the seasonal inhibition of luteinizing hormone secretion in the ewe. Endocrinology 140:1111-1117

270. Anderson GM, Hardy SL, Valent M, Billings HJ, Connors JM, Goodman RL 2003 Evidence that thyroid hormones act in the ventromedial preoptic area and the premammillary region of the brain to allow the termination of the breeding season in the ewe. Endocrinology 144:2892-2901

271. Dallman MF, Strack AM, Akana SF, Bradbury MJ, Hanson ES, Scribner KA, Smith M 1993 Feast and famine: critical role of glucocorticoids with insulin in daily energy flow. Front Neuroendocrinol 14:303-347

272. Rivier C, Rivier J, Vale W 1986 Stress-induced inhibition of reproductive functions: role of endogenous corticotropin-releasing factor. Science 231:607-609 
273. Juniewicz PE, Johnson BH, Bolt DJ 1987 Effect of adrenal steroids on testosterone and luteinizing hormone secretion in the ram. J Androl 8:190-196

274. Turner AI, Hemsworth PH, Canny BJ, Tilbrook AJ 1999 Inhibition of the secretion of LH in ovariectomised pigs by sustained but not repeated acute elevation of cortisol in the absence but not the presence of oestradiol. J Endocrinol 163:477-486

275. Turner AI, Hemsworth PH, Canny BJ, Tilbrook AJ 1999 Sustained but not repeated acute elevation of cortisol impaired the luteinizing hormone surge, estrus, and ovulation in gilts. Biol Reprod 61:614-620

276. Thibier M, Rolland O 1976 The effect of dexamethasone (DXM) on circulating testosterone $(\mathrm{T})$ and luteinizing hormone $(\mathrm{LH})$ in young postpubertal bulls. Theriogenology 5:53-60

277. Dubey AK, Plant TM 1985 A suppression of gonadotropin secretion by cortisol in castrated male rhesus monkeys (Macaca mulatta) mediated by the interruption of hypothalamic gonadotropin-releasing hormone release. Biol Reprod 33:423431

278. Saketos M, Sharma N, Santoro NF 1993 Suppression of the hypothalamicpituitary-ovarian axis in normal women by glucocorticoids. Biol Reprod 49:12701276

279. Phillips DJ, Clarke IJ 1990 Effects of the synthetic glucocorticoid dexamethasone on reproductive function in the ewe. J Endocrinol 126:289-295

280. Fuquay JW, Moberg GP 1983 Influence of the pituitary-adrenal axis on the induced release of luteinizing hormone in rams. J Endocrinol 99:151-155

281. Daley CA, Sakurai H, Adams BM, Adams TE 1999 Effect of stress-like concentrations of cortisol on gonadotroph function in orchidectomized sheep. Biol Reprod 60:158-163

282. Adams TE, Sakurai H, Adams BM 1999 Effect of stress-like concentrations of cortisol on estradiol-dependent expression of gonadotropin-releasing hormone receptor in orchidectomized sheep. Biol Reprod 60:164-168

283. Turner AI, Hemsworth PH, Hughes PE, Tilbrook AJ 1998 Repeated acute activation of the hypothalamo-pituitary adrenal axis prior to and during estrus did not affect reproductive performance in gilts. Biol Reprod 58:1458-1462

284. Samuels MH, Luther M, Henry P, Ridgway EC 1994 Effects of hydrocortisone on pulsatile pituitary glycoprotein secretion. J Clin Endocrinol Metab 78:211-215 
285. Tilbrook AJ, Turner AI, Clarke IJ 2000 Effects of stress on reproduction in non-rodent mammals: the role of glucocorticoids and sex differences. Rev Reprod 5:105-113

286. Coleman DL, Hummel KP 1973 The influence of genetic background on the expression of the obese $(\mathrm{Ob})$ gene in the mouse. Diabetologia 9:287-293

287. Ingalls AM, Dickie MM, Snell GD 1996 Obese, a new mutation in the house mouse. Obes Res 4:101

288. Coleman DL 1973 Effects of parabiosis of obese with diabetes and normal mice. Diabetologia 9:294-298

289. Zhang Y, Proenca R, Maffei M, Barone M, Leopold L, Friedman JM 1994 Positional cloning of the mouse obese gene and its human homologue. Nature $372: 425-432$

290. Campfield LA, Smith FJ, Guisez Y, Devos R, Burn P 1995 Recombinant mouse OB protein: evidence for a peripheral signal linking adiposity and central neural networks. Science 269:546-549

291. Halaas JL, Gajiwala KS, Maffei M, Cohen SL, Chait BT, Rabinowitz D, Lallone RL, Burley SK, Friedman JM 1995 Weight-reducing effects of the plasma protein encoded by the obese gene. Science 269:543-546

292. Pelleymounter MA, Cullen MJ, Baker MB, Hecht R, Winters D, Boone T, Collins F 1995 Effects of the obese gene product on body weight regulation in ob/ob mice. Science 269:540-543

293. Considine RV, Sinha MK, Heiman ML, Kriauciunas A, Stephens TW, Nyce MR, Ohannesian JP, Marco CC, McKee LJ, Bauer TL, . 1996 Serum immunoreactive-leptin concentrations in normal-weight and obese humans. $\mathrm{N}$ Engl J Med 334:292-295

294. Finn PD, Cunningham MJ, Pau KY, Spies HG, Clifton DK, Steiner RA 1998 The stimulatory effect of leptin on the neuroendocrine reproductive axis of the monkey. Endocrinology 139:4652-4662

295. Heiman ML, Ahima RS, Craft LS, Schoner B, Stephens TW, Flier JS 1997 Leptin inhibition of the hypothalamic-pituitary-adrenal axis in response to stress. Endocrinology 138:3859-3863

296. Vuagnat BA, Pierroz DD, Lalaoui M, Englaro P, Pralong FP, Blum WF, Aubert ML 1998 Evidence for a leptin-neuropeptide Y axis for the regulation of growth hormone secretion in the rat. Neuroendocrinology 67:291-300 
297. Frederich RC, Lollmann B, Hamann A, Napolitano-Rosen A, Kahn BB, Lowell BB, Flier JS 1995 Expression of ob mRNA and its encoded protein in rodents. Impact of nutrition and obesity. J Clin Invest 96:1658-1663

298. Yura S, Ogawa Y, Sagawa N, Masuzaki H, Itoh H, Ebihara K, Aizawa-Abe M, Fujii S, Nakao K 2000 Accelerated puberty and late-onset hypothalamic hypogonadism in female transgenic skinny mice overexpressing leptin. J Clin Invest 105:749-755

299. Swerdloff RS, Batt RA, Bray GA 1976 Reproductive hormonal function in the genetically obese (ob/ob) mouse. Endocrinology 98:1359-1364

300. Swerdloff RS, Peterson M, Vera A, Batt RA, Heber D, Bray GA 1978 The hypothalamic-pituitary axis in genetically obese (ob/ob) mice: response to luteinizing hormone-releasing hormone. Endocrinology 103:542-547

301. Chen H, Charlat O, Tartaglia LA, Woolf EA, Weng X, Ellis SJ, Lakey ND, Culpepper J, Moore KJ, Breitbart RE, Duyk GM, Tepper RI, Morgenstern JP 1996 Evidence that the diabetes gene encodes the leptin receptor: identification of a mutation in the leptin receptor gene in $\mathrm{db} / \mathrm{db}$ mice. Cell 84:491495

302. Chua SC, Jr., Chung WK, Wu-Peng XS, Zhang Y, Liu SM, Tartaglia L, Leibel RL 1996 Phenotypes of mouse diabetes and rat fatty due to mutations in the OB (leptin) receptor. Science 271:994-996

303. Lee GH, Proenca R, Montez JM, Carroll KM, Darvishzadeh JG, Lee JI, Friedman JM 1996 Abnormal splicing of the leptin receptor in diabetic mice. Nature 379:632-635

304. Clement K, Vaisse C, Lahlou N, Cabrol S, Pelloux V, Cassuto D, Gourmelen M, Dina C, Chambaz J, Lacorte JM, Basdevant A, Bougneres P, Lebouc Y, Froguel P, Guy-Grand B 1998 A mutation in the human leptin receptor gene causes obesity and pituitary dysfunction. Nature 392:398-401

305. Ahima RS, Dushay J, Flier SN, Prabakaran D, Flier JS 1997 Leptin accelerates the onset of puberty in normal female mice. J Clin Invest 99:391-395

306. Chehab FF, Mounzih K, Lu R, Lim ME 1997 Early onset of reproductive function in normal female mice treated with leptin. Science 275:88-90

307. Cheung CC, Thornton JE, Kuijper JL, Weigle DS, Clifton DK, Steiner RA 1997 Leptin is a metabolic gate for the onset of puberty in the female rat. Endocrinology 138:855-858 
308. Suter KJ, Pohl CR, Wilson ME 2000 Circulating concentrations of nocturnal leptin, growth hormone, and insulin-like growth factor-I increase before the onset of puberty in agonadal male monkeys: potential signals for the initiation of puberty. J Clin Endocrinol Metab 85:808-814

309. Garcia-Mayor RV, Andrade MA, Rios M, Lage M, Dieguez C, Casanueva FF 1997 Serum leptin levels in normal children: relationship to age, gender, body mass index, pituitary-gonadal hormones, and pubertal stage. J Clin Endocrinol Metab 82:2849-2855

310. Mantzoros CS, Flier JS, Rogol AD 1997 A longitudinal assessment of hormonal and physical alterations during normal puberty in boys. V. Rising leptin levels may signal the onset of puberty. J Clin Endocrinol Metab 82:1066-1070

311. Cheung CC, Thornton JE, Nurani SD, Clifton DK, Steiner RA 2001 A reassessment of leptin's role in triggering the onset of puberty in the rat and mouse. Neuroendocrinology 74:12-21

312. Cunningham MJ, Clifton DK, Steiner RA 1999 Leptin's actions on the reproductive axis: perspectives and mechanisms. Biol Reprod 60:216-222

313. Maciel MN, Zieba DA, Amstalden M, Keisler DH, Neves JP, Williams GL 2004 Leptin prevents fasting-mediated reductions in pulsatile secretion of luteinizing hormone and enhances its gonadotropin-releasing hormone-mediated release in heifers. Biol Reprod 70:229-235

314. Nagatani S, Guthikonda P, Thompson RC, Tsukamura H, Maeda KI, Foster DL 1998 Evidence for GnRH regulation by leptin: leptin administration prevents reduced pulsatile LH secretion during fasting. Neuroendocrinology 67:370-376

315. Zamorano PL, Mahesh VB, De Sevilla LM, Chorich LP, Bhat GK, Brann DW 1997 Expression and localization of the leptin receptor in endocrine and neuroendocrine tissues of the rat. Neuroendocrinology 65:223-228

316. Yu WH, Kimura M, Walczewska A, Karanth S, McCann SM 1997 Role of leptin in hypothalamic-pituitary function. Proc Natl Acad Sci U S A 94:10231028

317. Hakansson ML, Brown H, Ghilardi N, Skoda RC, Meister B 1998 Leptin receptor immunoreactivity in chemically defined target neurons of the hypothalamus. J Neurosci 18:559-572

318. Carro E, Senaris R, Considine RV, Casanueva FF, Dieguez C 1997 Regulation of in vivo growth hormone secretion by leptin. Endocrinology 138:2203-2206 
319. Nagatani S, Zeng Y, Keisler DH, Foster DL, Jaffe CA 2000 Leptin regulates pulsatile luteinizing hormone and growth hormone secretion in the sheep. Endocrinology 141:3965-3975

320. Karlsson C, Lindell K, Svensson E, Bergh C, Lind P, Billig H, Carlsson LM, Carlsson B 1997 Expression of functional leptin receptors in the human ovary. J Clin Endocrinol Metab 82:4144-4148

321. Caprio M, Isidori AM, Carta AR, Moretti C, Dufau ML, Fabbri A 1999 Expression of functional leptin receptors in rodent Leydig cells. Endocrinology 140:4939-4947

322. Isidori AM, Caprio M, Strollo F, Moretti C, Frajese G, Isidori A, Fabbri A 1999 Leptin and androgens in male obesity: evidence for leptin contribution to reduced androgen levels. J Clin Endocrinol Metab 84:3673-3680

323. Sudo M, Minokoshi Y, Shimazu T 1991 Ventromedial hypothalamic stimulation enhances peripheral glucose uptake in anesthetized rats. Am J Physiol 261:E298E303

324. Panicker AK, Mangels RA, Powers JB, Wade GN, Schneider JE 1998 AP lesions block suppression of estrous behavior, but not estrous cyclicity, in fooddeprived Syrian hamsters. Am J Physiol 275:R158-R164

325. Wilding JP 2002 Neuropeptides and appetite control. Diabet Med 19:619-627

326. Tatemoto K, Carlquist M, Mutt V 1982 Neuropeptide Y--a novel brain peptide with structural similarities to peptide YY and pancreatic polypeptide. Nature 296:659-660

327. Tatemoto K 1982 Neuropeptide Y: complete amino acid sequence of the brain peptide. Proc Natl Acad Sci U S A 79:5485-5489

328. Thorsell A, Heilig M 2002 Diverse functions of neuropeptide Y revealed using genetically modified animals. Neuropeptides 36:182-193

329. Leibowitz SF 1991 Brain neuropeptide Y: an integrator of endocrine, metabolic and behavioral processes. Brain Res Bull 27:333-337

330. Beck B, Jhanwar-Uniyal M, Burlet A, Chapleur-Chateau M, Leibowitz SF, Burlet C 1990 Rapid and localized alterations of neuropeptide Y in discrete hypothalamic nuclei with feeding status. Brain Res 528:245-249

331. Kalra SP, Dube MG, Sahu A, Phelps CP, Kalra PS 1991 Neuropeptide Y secretion increases in the paraventricular nucleus in association with increased appetite for food. Proc Natl Acad Sci U S A 88:10931-10935 
332. Michel MC, Beck-Sickinger A, Cox H, Doods HN, Herzog H, Larhammar D, Quirion R, Schwartz T, Westfall T 1998 XVI. International Union of Pharmacology recommendations for the nomenclature of neuropeptide $Y$, peptide YY, and pancreatic polypeptide receptors. Pharmacol Rev 50:143-150

333. Caberlotto L, Tinner B, Bunnemann B, Agnati L, Fuxe K 1998 On the relationship of neuropeptide Y Y1 receptor-immunoreactive neuronal structures to the neuropeptide $\mathrm{Y}$-immunoreactive nerve terminal networks. A double immunolabelling analysis in the rat brain. Neuroscience 86:827-845

334. Naveilhan P, Neveu I, Arenas E, Ernfors P 1998 Complementary and overlapping expression of Y1, Y2 and Y5 receptors in the developing and adult mouse nervous system. Neuroscience 87:289-302

335. Parker RM, Herzog H 1999 Regional distribution of Y-receptor subtype mRNAs in rat brain. Eur J Neurosci 11:1431-1448

336. Nichol KA, Morey A, Couzens MH, Shine J, Herzog H, Cunningham AM 1999 Conservation of expression of neuropeptide Y5 receptor between human and rat hypothalamus and limbic regions suggests an integral role in central neuroendocrine control. J Neurosci 19:10295-10304

337. Gerald C, Walker MW, Criscione L, Gustafson EL, Batzl-Hartmann C, Smith KE, Vaysse P, Durkin MM, Laz TM, Linemeyer DL, Schaffhauser AO, Whitebread S, Hofbauer KG, Taber RI, Branchek TA, Weinshank RL 1996 A receptor subtype involved in neuropeptide-Y-induced food intake. Nature 382:168-171

338. Schaffhauser AO, Stricker-Krongrad A, Brunner L, Cumin F, Gerald C, Whitebread S, Criscione L, Hofbauer KG 1997 Inhibition of food intake by neuropeptide Y Y5 receptor antisense oligodeoxynucleotides. Diabetes 46:17921798

339. Clark JT, Kalra PS, Crowley WR, Kalra SP 1984 Neuropeptide Y and human pancreatic polypeptide stimulate feeding behavior in rats. Endocrinology $115: 427-429$

340. Kalra SP, Kalra PS 1996 Nutritional infertility: the role of the interconnected hypothalamic neuropeptide Y-galanin-opioid network. Front Neuroendocrinol 17:371-401

341. Levine AS, Morley JE 1984 Neuropeptide Y: a potent inducer of consummatory behavior in rats. Peptides 5:1025-1029

342. Stanley BG, Leibowitz SF 1985 Neuropeptide Y injected in the paraventricular hypothalamus: a powerful stimulant of feeding behavior. Proc Natl Acad Sci U S A 82:3940-3943 
343. Zarjevski N, Cusin I, Vettor R, Rohner-Jeanrenaud F, Jeanrenaud B 1993 Chronic intracerebroventricular neuropeptide-Y administration to normal rats mimics hormonal and metabolic changes of obesity. Endocrinology 133:17531758

344. Stanley BG, Kyrkouli SE, Lampert S, Leibowitz SF 1986 Neuropeptide Y chronically injected into the hypothalamus: a powerful neurochemical inducer of hyperphagia and obesity. Peptides 7:1189-1192

345. Kalra SP, Dube MG, KaIra PS 1988 Continuous intraventricular infusion of neuropeptide $\mathrm{Y}$ evokes episodic food intake in satiated female rats: effects of adrenalectomy and cholecystokinin. Peptides 9:723-728

346. Flood JF, Morley JE 1991 Increased food intake by neuropeptide $Y$ is due to an increased motivation to eat. Peptides 12:1329-1332

347. Sahu A, Kalra PS, Kalra SP 1988 Food deprivation and ingestion induce reciprocal changes in neuropeptide $\mathrm{Y}$ concentrations in the paraventricular nucleus. Peptides 9:83-86

348. Barker-Gibb ML, Clarke IJ 2000 Effect of season on neuropeptide Y and galanin within the hypothalamus of the ewe in relation to plasma luteinizing hormone concentrations and the breeding season: an immunohistochemical analysis. J Neuroendocrinol 12:618-626

349. Kalra SP 1993 Mandatory neuropeptide-steroid signaling for the preovulatory luteinizing hormone-releasing hormone discharge. Endocr Rev 14:507-538

350. Leibowitz SF, Akabayashi A, Alexander JT, Wang J 1998 Gonadal steroids and hypothalamic galanin and neuropeptide $\mathrm{Y}$ : role in eating behavior and body weight control in female rats. Endocrinology 139:1771-1780

351. Sahu A, Crowley WR, Kalra SP 1995 Evidence that hypothalamic neuropeptide Y gene expression increases before the onset of the preovulatory LH surge. J Neuroendocrinol 7:291-296

352. Watanobe H, Takebe K 1992 Evidence that neuropeptide Y secretion in the median eminence increases prior to the luteinizing hormone surge in ovariectomized steroid-primed rats: estimation by push-pull perfusion. Neurosci Lett 146:57-59

353. Xu M, Urban JH, Hill JW, Levine JE 2000 Regulation of hypothalamic neuropeptide Y Y1 receptor gene expression during the estrous cycle: role of progesterone receptors. Endocrinology 141:3319-3327 
354. Jain MR, Pu S, Kalra PS, Kalra SP 1999 Evidence that stimulation of two modalities of pituitary luteinizing hormone release in ovarian steroid-primed ovariectomized rats may involve neuropeptide Y Y1 and Y4 receptors. Endocrinology 140:5171-5177

355. Advis JP, Conover CK, McDonald JK, Kuljis RD 1990 Neuropeptide Y regulation of LHRH release in ewe median eminence: immunocytochemistry, tissue content, and in vivo analysis. Ann NY Acad Sci 611:468-470

356. Malven PV, Haglof SA, Jiang H 1995 Serum concentrations of luteinizing hormone, growth hormone, and prolactin in untreated and estradiol-treated ovariectomized ewes after immunoneutralization of hypothalamic neuropeptide Y. J Anim Sci 73:2105-2112

357. Porter DW, Naylor AM, McNeilly AS, Lincoln DW 1993 Endocrine actions of central neuropeptide $Y$ in the ewe: activation of the hypothalamo-pituitaryadrenal axis by exogenous neuropeptide $\mathrm{Y}$ and role of endogenous neuropeptide $\mathrm{Y}$ in the secretion of luteinizing hormone during the oestrous cycle. J Neuroendocrinol 5:163-174

358. Mizuno M, Gearing M, Terasawa E 2000 The role of neuropeptide $Y$ in the progesterone-induced luteinizing hormone-releasing hormone surge in vivo in ovariectomized female rhesus monkeys. Endocrinology 141:1772-1779

359. Woller MJ, Terasawa E 1994 Changes in pulsatile release of neuropeptide-Y and luteinizing hormone ( $\mathrm{LH}$ )-releasing hormone during the progesteroneinduced LH surge in rhesus monkeys. Endocrinology 135:1679-1686

360. Kalra SP, Fuentes M, Fournier A, Parker SL, Crowley WR 1992 Involvement of the Y-1 receptor subtype in the regulation of luteinizing hormone secretion by neuropeptide $\mathrm{Y}$ in rats. Endocrinology 130:3323-3330

361. Crowley WR, Kalra SP 1987 Neuropeptide Y stimulates the release of luteinizing hormone-releasing hormone from medial basal hypothalamus in vitro: modulation by ovarian hormones. Neuroendocrinology 46:97-103

362. Sabatino FD, Collins P, McDonald JK 1989 Neuropeptide-Y stimulation of luteinizing hormone-releasing hormone secretion from the median eminence in vitro by estrogen-dependent and extracellular $\mathrm{Ca} 2+$-independent mechanisms. Endocrinology 124:2089-2098

363. Sahu A, Crowley WR, Tatemoto K, Balasubramaniam A, Kalra SP 1987 Effects of neuropeptide Y, NPY analog (norleucine4-NPY), galanin and neuropeptide $\mathrm{K}$ on LH release in ovariectomized (ovx) and ovx estrogen, progesterone-treated rats. Peptides 8:921-926 
364. Woller MJ, Campbell GT, Liu L, Steigerwalt RW, Blake CA 1993 Estrogen alters the effects of neuropeptide-Y on luteinizing hormone and folliclestimulating hormone release in female rats at the level of the anterior pituitary gland. Endocrinology 133:2675-2681

365. Pau KY, Berria M, Hess DL, Spies HG 1995 Hypothalamic site-dependent effects of neuropeptide $\mathrm{Y}$ on gonadotropin-releasing hormone secretion in rhesus macaques. J Neuroendocrinol 7:63-67

366. Morrison CD, Daniel JA, Hampton JH, Buff PR, McShane TM, Thomas MG, Keisler DH 2003 Luteinizing hormone and growth hormone secretion in ewes infused intracerebroventricularly with neuropeptide Y. Domest Anim Endocrinol 24:69-80

367. Tsuruo Y, Kawano H, Kagotani Y, Hisano S, Daikoku S, Chihara K, Zhang T, Yanaihara N 1990 Morphological evidence for neuronal regulation of luteinizing hormone-releasing hormone-containing neurons by neuropeptide $\mathrm{Y}$ in the rat septo-preoptic area. Neurosci Lett 110:261-266

368. Jansen HT, Cutter C, Hardy S, Lehman MN, Goodman RL 2003 Seasonal plasticity within the gonadotropin-releasing hormone $(\mathrm{GnRH})$ system of the ewe: changes in identified GnRH inputs and glial association. Endocrinology 144:3663-3676

369. Skinner DC, Herbison AE 1997 Effects of photoperiod on estrogen receptor, tyrosine hydroxylase, neuropeptide $\mathrm{Y}$, and beta-endorphin immunoreactivity in the ewe hypothalamus. Endocrinology 138:2585-2595

370. Clarke IJ, Rao A, Chilliard Y, Delavaud C, Lincoln GA 2003 Photoperiod effects on gene expression for hypothalamic appetite-regulating peptides and food intake in the ram. Am J Physiol Regul Integr Comp Physiol 284:R101-R115

371. Erickson JC, Hollopeter G, Palmiter RD 1996 Attenuation of the obesity syndrome of ob/ob mice by the loss of neuropeptide Y. Science 274:1704-1707

372. Sainsbury A, Schwarzer C, Couzens M, Fetissov S, Furtinger S, Jenkins A, Cox HM, Sperk G, Hokfelt T, Herzog H 2002 Important role of hypothalamic Y2 receptors in body weight regulation revealed in conditional knockout mice. Proc Natl Acad Sci U S A 99:8938-8943

373. Murahashi K, Bucholtz DC, Nagatani S, Tsukahara S, Tsukamura H, Foster DL, Maeda KI 1996 Suppression of luteinizing hormone pulses by restriction of glucose availability is mediated by sensors in the brain stem. Endocrinology 137:1171-1176

374. Ritter S, Dinh TT, Zhang Y 2000 Localization of hindbrain glucoreceptive sites controlling food intake and blood glucose. Brain Res 856:37-47 
375. Gobel U, Schrock H, Seller H, Kuschinsky W 1990 Glucose utilization, blood flow and capillary density in the ventrolateral medulla of the rat. Pflugers Arch 416:477-480

376. Gross PM, Wainman DS, Shaver SW, Wall KM, Ferguson AV 1990 Metabolic activation of efferent pathways from the rat area postrema. Am J Physiol 258:R788-R797

377. Ritter S, Stone SL 1987 Area postrema lesions block feeding induced by systemic injections of monosodium glutamate. Physiol Behav 41:21-24

378. Cates PS, O'Byrne KT 2000 The area postrema mediates insulin hypoglycaemia-induced suppression of pulsatile LH secretion in the female rat. Brain Res 853:151-155

379. Schneider JE, Zhu Y 1994 Caudal brain stem plays a role in metabolic control of estrous cycles in Syrian hamsters. Brain Res 661:70-74

380. I'Anson H, Sundling LA, Roland SM, Ritter S 2003 Immunotoxic destruction of distinct catecholaminergic neuron populations disrupts the reproductive response to glucoprivation in female rats. Endocrinology 144:4325-4331

381. Barb CR, Kraeling RR, Rampacek GB 1991 Opioid modulation of gonadotropin and prolactin secretion in domestic farm animals. Domest Anim Endocrinol 8:15-27

382. Havern RL, Whisnant CS, Goodman RL 1991 Hypothalamic sites of catecholamine inhibition of luteinizing hormone in the anestrous ewe. Biol Reprod 44:476-482

383. Riggs BL, Malven PV 1974 Effects of intraventricular infusion of serotonin, norepinephrine, and dopamine on spontaneous LH release in castrate male sheep. Biol Reprod 11:587-592

384. Lehman MN, Durham DM, Jansen HT, Adrian B, Goodman RL 1996 Dopaminergic A14/A15 neurons are activated during estradiol negative feedback in anestrous, but not breeding season, ewes. Endocrinology 137:4443-4450

385. Ferreira SA, Scott CJ, Kuehl DE, Jackson GL 1996 Differential regulation of luteinizing hormone release by gamma-aminobutyric acid receptor subtypes in the arcuate-ventromedial region of the castrated ram. Endocrinology 137:3453-3460

386. Ferreira SA, Hileman SM, Kuehl DE, Jackson GL 1998 Effects of dialyzing gamma-aminobutyric acid receptor antagonists into the medial preoptic and arcuate ventromedial region on luteinizing hormone release in male sheep. Biol Reprod 58:1038-1046 
387. Caraty A, Skinner DC, Huyghe B, Bertault T, Picard S, Delaleu B, Malpaux B, Thiery JC 1998 The GnRH increase following progesterone withdrawal is associated with an increased glutamatergic tone in the preoptic area of the ovariectomized ewe. Ann N Y Acad Sci 839:363-364

388. Yeates NTM 1949 The breeding season of the sheep with particular reference to its modification by artificial means using light. J Agric Sci 39:1-43

389. Legan SJ, Karsch FJ 1980 Photoperiodic control of seasonal breeding in ewes: modulation of the negative feedback action of estradiol. Biol Reprod 23:10611068

390. Lincoln GA 1976 Seasonal variation in the episodic secretion of luteinizing hormone and testosterone in the ram. J Endocrinol 69:213-226

391. Lincoln GA 1976 Secretion of LH in rams exposed to two different photoperiods. J Reprod Fertil 47:351-353

392. Lincoln GA 1984 Central effects of photoperiod on reproduction in the ram revealed by the use of a testosterone clamp. J Endocrinol 103:233-241

393. Huang X, Harlan RE 1993 Absence of androgen receptors in LHRH immunoreactive neurons. Brain Res 624:309-311

394. Shivers BD, Harlan RE, Morrell JI, Pfaff DW 1983 Absence of oestradiol concentration in cell nuclei of LHRH-immunoreactive neurones. Nature 304:345347

395. Hrabovszky E, Shughrue PJ, Merchenthaler I, Hajszan T, Carpenter CD, Liposits Z, Petersen SL 2000 Detection of estrogen receptor-beta messenger ribonucleic acid and 125I-estrogen binding sites in luteinizing hormone-releasing hormone neurons of the rat brain. Endocrinology 141:3506-3509

396. Hrabovszky E, Steinhauser A, Barabas K, Shughrue PJ, Petersen SL, Merchenthaler I, Liposits Z 2001 Estrogen receptor-beta immunoreactivity in luteinizing hormone-releasing hormone neurons of the rat brain. Endocrinology 142:3261-3264

397. Kallo I, Butler JA, Barkovics-Kallo M, Goubillon ML, Coen CW 2001 Oestrogen receptor beta-immunoreactivity in gonadotropin releasing hormoneexpressing neurones: regulation by oestrogen. J Neuroendocrinol 13:741-748

398. Herbison AE, Pape JR 2001 New evidence for estrogen receptors in gonadotropin-releasing hormone neurons. Front Neuroendocrinol 22:292-308

399. Mercer JG 1998 Regulation of appetite and body weight in seasonal mammals. Comp Biochem Physiol C Pharmacol Toxicol Endocrinol 119:295-303 
400. Tatemoto K, Carlquist M, Mutt V 1982 Neuropeptide Y--a novel brain peptide with structural similarities to peptide YY and pancreatic polypeptide. Nature 296:659-660

401. Tatemoto K 1982 Neuropeptide Y: complete amino acid sequence of the brain peptide. Proc Natl Acad Sci U S A 79:5485-5489

402. Barker-Gibb ML, Scott CJ, Boublik JH, Clarke IJ 1995 The role of neuropeptide Y (NPY) in the control of LH secretion in the ewe with respect to season, NPY receptor subtype and the site of action in the hypothalamus. J Endocrinol 147:565-579

403. Bauer-Dantoin AC, Knox KL, Schwartz NB, Levine JE 1993 Estrous cycle stage-dependent effects of neuropeptide-Y on luteinizing hormone (LH)-releasing hormone-stimulated $\mathrm{LH}$ and follicle-stimulating hormone secretion from anterior pituitary fragments in vitro. Endocrinology 133:2413-2417

404. Malven PV, Haglof SA, Degroot H 1992 Effects of intracerebral administration of neuropeptide-Y on secretion of luteinizing hormone in ovariectomized sheep. Brain Res Bull 28:871-875

405. Woller MJ, Terasawa E 1991 Infusion of neuropeptide Y into the stalk-median eminence stimulates in vivo release of luteinizing hormone-release hormone in gonadectomized rhesus monkeys. Endocrinology 128:1144-1150

406. Tillet Y, Caldani M, Batailler M 1989 Anatomical relationships of monoaminergic and neuropeptide $\mathrm{Y}$-containing fibres with luteinizing hormonereleasing hormone systems in the preoptic area of the sheep brain: immunohistochemical studies. J Chem Neuroanat 2:319-326

407. Sar M, Sahu A, Crowley WR, Kalra SP 1990 Localization of neuropeptide-Y immunoreactivity in estradiol-concentrating cells in the hypothalamus. Endocrinology 127:2752-2756

408. Clarke IJ, Rao A, Chilliard Y, Delavaud C, Lincoln GA 2003 Photoperiod effects on gene expression for hypothalamic appetite-regulating peptides and food intake in the ram. Am J Physiol Regul Integr Comp Physiol 284:R101-R115

409. Barker-Gibb ML, Clarke IJ 2000 Effect of season on neuropeptide Y and galanin within the hypothalamus of the ewe in relation to plasma luteinizing hormone concentrations and the breeding season: an immunohistochemical analysis. J Neuroendocrinol 12:618-626

410. Skinner DC, Herbison AE 1997 Effects of photoperiod on estrogen receptor, tyrosine hydroxylase, neuropeptide $\mathrm{Y}$, and beta-endorphin immunoreactivity in the ewe hypothalamus. Endocrinology 138:2585-2595 
411. Hileman SM, Kuehl DE, Jackson GL 1998 Photoperiod affects the ability of testosterone to alter proopiomelanocortin mRNA, but not luteinizing hormonereleasing hormone mRNA, levels in male sheep. J Neuroendocrinol 10:587-592

412. Hileman SM, Kuehl DE, Jackson GL 1998 Photoperiod affects the ability of testosterone to alter proopiomelanocortin mRNA, but not luteinizing hormonereleasing hormone mRNA, levels in male sheep. J Neuroendocrinol 10:587-592

413. Hileman SM, Kuehl DE, Jackson GL 1998 Photoperiod affects the ability of testosterone to alter proopiomelanocortin mRNA, but not luteinizing hormonereleasing hormone mRNA, levels in male sheep. J Neuroendocrinol 10:587-592

414. Greco B, Lubbers LS, Blaustein JD 2003 Estrogen receptor beta messenger ribonucleic acid expression in the forebrain of proestrous, pregnant, and lactating female rats. Endocrinology 144:1869-1875

415. Hileman SM, Kuehl DE, Jackson GL 1998 Photoperiod affects the ability of testosterone to alter proopiomelanocortin mRNA, but not luteinizing hormonereleasing hormone mRNA, levels in male sheep. J Neuroendocrinol 10:587-592

416. Leibowitz SF, Akabayashi A, Alexander JT, Wang J 1998 Gonadal steroids and hypothalamic galanin and neuropeptide Y: role in eating behavior and body weight control in female rats. Endocrinology 139:1771-1780

417. Sahu A, Crowley WR, Kalra SP 1990 An opioid-neuropeptide-Y transmission line to luteinizing hormone (LH)-releasing hormone neurons: a role in the induction of LH surge. Endocrinology 126:876-883

418. Sahu A, Crowley WR, Kalra SP 1995 Evidence that hypothalamic neuropeptide Y gene expression increases before the onset of the preovulatory LH surge. $\mathrm{J}$ Neuroendocrinol 7:291-296

419. Watanobe H, Takebe K 1992 Evidence that neuropeptide Y secretion in the median eminence increases prior to the luteinizing hormone surge in ovariectomized steroid-primed rats: estimation by push-pull perfusion. Neurosci Lett 146:57-59

420. Xu M, Urban JH, Hill JW, Levine JE 2000 Regulation of hypothalamic neuropeptide Y Y1 receptor gene expression during the estrous cycle: role of progesterone receptors. Endocrinology 141:3319-3327

421. Jain MR, Pu S, Kalra PS, Kalra SP 1999 Evidence that stimulation of two modalities of pituitary luteinizing hormone release in ovarian steroid-primed ovariectomized rats may involve neuropeptide Y Y1 and Y4 receptors. Endocrinology 140:5171-5177 
422. Kalra PS, Bonavera JJ, Kalra SP 1995 Central administration of antisense oligodeoxynucleotides to neuropeptide Y (NPY) mRNA reveals the critical role of newly synthesized NPY in regulation of LHRH release. Regul Pept 59:215-220

423. Advis JP, Conover CK, McDonald JK, Kuljis RD 1990 Neuropeptide Y regulation of LHRH release in ewe median eminence: immunocytochemistry, tissue content, and in vivo analysis. Ann NY Acad Sci 611:468-470

424. Porter DW, Naylor AM, McNeilly AS, Lincoln DW 1993 Endocrine actions of central neuropeptide $\mathrm{Y}$ in the ewe: activation of the hypothalamo-pituitaryadrenal axis by exogenous neuropeptide $\mathrm{Y}$ and role of endogenous neuropeptide $\mathrm{Y}$ in the secretion of luteinizing hormone during the oestrous cycle. J Neuroendocrinol 5:163-174

425. Mizuno M, Gearing M, Terasawa $\mathbf{E} 2000$ The role of neuropeptide $Y$ in the progesterone-induced luteinizing hormone-releasing hormone surge in vivo in ovariectomized female rhesus monkeys. Endocrinology 141:1772-1779

426. Woller MJ, Terasawa E 1994 Changes in pulsatile release of neuropeptide-Y and luteinizing hormone ( $\mathrm{LH}$ )-releasing hormone during the progesteroneinduced LH surge in rhesus monkeys. Endocrinology 135:1679-1686

427. Xu M, Hill JW, Levine JE 2000 Attenuation of luteinizing hormone surges in neuropeptide Y knockout mice. Neuroendocrinology 72:263-271

428. Kalra SP, Fuentes M, Fournier A, Parker SL, Crowley WR 1992 Involvement of the Y-1 receptor subtype in the regulation of luteinizing hormone secretion by neuropeptide $\mathrm{Y}$ in rats. Endocrinology 130:3323-3330

429. Sahu A, Crowley WR, Tatemoto K, Balasubramaniam A, Kalra SP 1987 Effects of neuropeptide Y, NPY analog (norleucine4-NPY), galanin and neuropeptide $\mathrm{K}$ on LH release in ovariectomized (ovx) and ovx estrogen, progesterone-treated rats. Peptides 8:921-926

430. Sabatino FD, Collins P, McDonald JK 1989 Neuropeptide-Y stimulation of luteinizing hormone-releasing hormone secretion from the median eminence in vitro by estrogen-dependent and extracellular $\mathrm{Ca} 2+$-independent mechanisms. Endocrinology 124:2089-2098

431. Crowley WR, Kalra SP 1987 Neuropeptide Y stimulates the release of luteinizing hormone-releasing hormone from medial basal hypothalamus in vitro: modulation by ovarian hormones. Neuroendocrinology 46:97-103

432. Woller MJ, Campbell GT, Liu L, Steigerwalt RW, Blake CA 1993 Estrogen alters the effects of neuropeptide-Y on luteinizing hormone and folliclestimulating hormone release in female rats at the level of the anterior pituitary gland. Endocrinology 133:2675-2681 
433. Woller MJ, Terasawa E 1992 Estradiol enhances the action of neuropeptide $Y$ on in vivo luteinizing hormone-releasing hormone release in the ovariectomized rhesus monkey. Neuroendocrinology 56:921-925

434. Woller MJ, Terasawa E 1991 Infusion of neuropeptide Y into the stalk-median eminence stimulates in vivo release of luteinizing hormone-release hormone in gonadectomized rhesus monkeys. Endocrinology 128:1144-1150

435. Pau KY, Berria M, Hess DL, Spies HG 1995 Hypothalamic site-dependent effects of neuropeptide $\mathrm{Y}$ on gonadotropin-releasing hormone secretion in rhesus macaques. J Neuroendocrinol 7:63-67

436. Pau KY, Berria M, Hess DL, Spies HG 1995 Hypothalamic site-dependent effects of neuropeptide $\mathrm{Y}$ on gonadotropin-releasing hormone secretion in rhesus macaques. J Neuroendocrinol 7:63-67

437. Thomas MG, Gazal OS, Williams GL, Stanko RL, Keisler DH 1999 Injection of neuropeptide $Y$ into the third cerebroventricle differentially influences pituitary secretion of luteinizing hormone and growth hormone in ovariectomized cows. Domest Anim Endocrinol 16:159-169

438. Morrison CD, Daniel JA, Hampton JH, Buff PR, McShane TM, Thomas MG, Keisler DH 2003 Luteinizing hormone and growth hormone secretion in ewes infused intracerebroventricularly with neuropeptide Y. Domest Anim Endocrinol 24:69-80

439. McShane TM, May T, Miner JL, Keisler DH 1992 Central actions of neuropeptide-Y may provide a neuromodulatory link between nutrition and reproduction. Biol Reprod 46:1151-1157

440. Malven PV, Haglof SA, Degroot H 1992 Effects of intracerebral administration of neuropeptide-Y on secretion of luteinizing hormone in ovariectomized sheep. Brain Res Bull 28:871-875

441. Barker-Gibb ML, Scott CJ, Boublik JH, Clarke IJ 1995 The role of neuropeptide Y (NPY) in the control of LH secretion in the ewe with respect to season, NPY receptor subtype and the site of action in the hypothalamus. J Endocrinol 147:565-579

442. Gazal OS, Leshin LS, Stanko RL, Thomas MG, Keisler DH, Anderson LL, Williams GL 1998 Gonadotropin-releasing hormone secretion into third-ventricle cerebrospinal fluid of cattle: correspondence with the tonic and surge release of luteinizing hormone and its tonic inhibition by suckling and neuropeptide Y. Biol Reprod 59:676-683

443. Adam CL, Findlay PA, Kyle CE, Young P, Mercer JG 1997 Effect of chronic food restriction on pulsatile luteinizing hormone secretion and hypothalamic neuropeptide Y gene expression in castrate male sheep. J Endocrinol 152:329-337 
444. McShane TM, Petersen SL, McCrone S, Keisler DH 1993 Influence of food restriction on neuropeptide-Y, proopiomelanocortin, and luteinizing hormonereleasing hormone gene expression in sheep hypothalami. Biol Reprod 49:831839

445. Clarke IJ, Rao A, Chilliard Y, Delavaud C, Lincoln GA 2003 Photoperiod effects on gene expression for hypothalamic appetite-regulating peptides and food intake in the ram. Am J Physiol Regul Integr Comp Physiol 284:R101-R115

446. Nowicki M, Bryc W, Kokot F 2001 Hormonal regulation of appetite and body mass in patients with advanced prostate cancer treated with combined androgen blockade. J Endocrinol Invest 24:31-36

447. Baranowska B, Radzikowska M, Wasilewska-Dziubinska E, Kaplinski A, Roguski K, Plonowski A 1999 Neuropeptide Y, leptin, galanin and insulin in women with polycystic ovary syndrome. Gynecol Endocrinol 13:344-351

448. Sohn EH, Wolden-Hanson T, Matsumoto AM 2002 Testosterone (T)-induced changes in arcuate nucleus cocaine-amphetamine-regulated transcript and NPY mRNA are attenuated in old compared to young male brown Norway rats: contribution of $\mathrm{T}$ to age-related changes in cocaine-amphetamine-regulated transcript and NPY gene expression. Endocrinology 143:954-963

449. Sahu A, Phelps CP, White JD, Crowley WR, Kalra SP, Kalra PS 1992 Steroidal regulation of hypothalamic neuropeptide $\mathrm{Y}$ release and gene expression. Endocrinology 130:3331-3336

450. Diez-Guerra FJ, Bicknell RJ, Mansfield S, Emson PC, Dyer RG 1987 Effect of neonatal testosterone upon opioid receptors and the content of beta-endorphin, neuropeptide $\mathrm{Y}$ and neurotensin in the medial preoptic and the mediobasal hypothalamic areas of the rat brain. Brain Res 424:225-230

451. Sahu A, Kalra SP, Crowley WR, Kalra PS 1989 Testosterone raises neuropeptide-Y concentration in selected hypothalamic sites and in vitro release from the medial basal hypothalamus of castrated male rats. Endocrinology $124: 410-414$

452. Urban JH, Bauer-Dantoin AC, Levine JE 1993 Neuropeptide Y gene expression in the arcuate nucleus: sexual dimorphism and modulation by testosterone. Endocrinology 132:139-145

453. Urban JH, Das I, Levine JE 1996 Steroid modulation of neuropeptide Yinduced luteinizing hormone releasing hormone release from median eminence fragments from male rats. Neuroendocrinology 63:112-119 
454. EI Majdoubi M, Ramaswamy S, Sahu A, Plant TM 2000 Effects of orchidectomy on levels of the mRNAs encoding gonadotropin-releasing hormone and other hypothalamic peptides in the adult male rhesus monkey (Macaca mulatta). J Neuroendocrinol 12:167-176

455. Khorram O, Roselli CE, Ellinwood WE, Spies HG 1987 The measurement of neuropeptide $\mathrm{Y}$ in discrete hypothalamic and limbic regions of male rhesus macaques with a human NPY-directed antiserum. Peptides 8:159-163

456. Barker-Gibb ML, Scott CJ, Boublik JH, Clarke IJ 1995 The role of neuropeptide Y (NPY) in the control of LH secretion in the ewe with respect to season, NPY receptor subtype and the site of action in the hypothalamus. J Endocrinol 147:565-579

457. Sahu A, Crowley WR, Kalra PS, Kalra SP 1992 A selective sexually dimorphic response in the median eminence neuropeptide Y. Brain Res 573:235-242

458. Sahu A, Crowley WR, Kalra PS, Kalra SP 1992 A selective sexually dimorphic response in the median eminence neuropeptide Y. Brain Res 573:235-242

459. Baskin DG, Norwood BJ, Schwartz MW, Koerker DJ 1995 Estradiol inhibits the increase of hypothalamic neuropeptide Y messenger ribonucleic acid expression induced by weight loss in ovariectomized rats. Endocrinology 136:5547-5554

460. Bonavera JJ, Dube MG, Kalra PS, Kalra SP 1994 Anorectic effects of estrogen may be mediated by decreased neuropeptide-Y release in the hypothalamic paraventricular nucleus. Endocrinology 134:2367-2370

461. Shimizu H, Ohtani K, Kato Y, Tanaka Y, Mori M 1996 Withdrawal of [corrected] estrogen increases hypothalamic neuropeptide Y (NPY) mRNA expression in ovariectomized obese rat. Neurosci Lett 204:81-84

462. Hileman SM, Lubbers LS, Kuehl DE, Schaeffer DJ, Rhodes L, Jackson GL 1994 Effect of inhibiting 5 alpha-reductase activity on the ability of testosterone to inhibit luteinizing hormone release in male sheep. Biol Reprod 50:1244-1250

463. Gomez F, Dallman MF 2001 Manipulation of androgens causes different energetic responses to cold in 60- and 40-day-old male rats. Am J Physiol Regul Integr Comp Physiol 280:R262-R273

464. Kemnitz JW, Sladky KK, Flitsch TJ, Pomerantz SM, Goy RW 1988 Androgenic influences on body size and composition of adult rhesus monkeys. Am J Physiol 255:E857-E864

465. Earley CJ, Leonard BE 1979 Androgens, estrogens and their anti-hormones: effects on body weight and food consumption. Pharmacol Biochem Behav $11: 211-214$ 
466. Gentry RT, Wade GN 1976 Androgenic control of food intake and body weight in male rats. J Comp Physiol Psychol 90:18-25

467. Wu-Peng S, Rosenbaum M, Nicolson M, Chua SC, Leibel RL 1999 Effects of exogenous gonadal steroids on leptin homeostasis in rats. Obes Res 7:586-592

468. Richard D, Picard F, Lemieux C, Lalonde J, Samson P, Deshaies Y 2002 The effects of topiramate and sex hormones on energy balance of male and female rats. Int J Obes Relat Metab Disord 26:344-353

469. Kemnitz JW, Sladky KK, Flitsch TJ, Pomerantz SM, Goy RW 1988 Androgenic influences on body size and composition of adult rhesus monkeys. Am J Physiol 255:E857-E864

470. Lobley GE, Connell A, Buchan V, Skene PA, Fletcher JM 1987 Administration of testosterone to wether lambs: effects on protein and energy metabolism and growth hormone status. J Endocrinol 115:439-445

471. Czaja JA 1984 Sex differences in the activational effects of gonadal hormones on food intake and body weight. Physiol Behav 33:553-558

472. Nunez AA, Grundman M 1982 Testosterone affects food intake and body weight of weanling male rats. Pharmacol Biochem Behav 16:933-936

473. Mauer MM, Bartness TJ 1995 A role for testosterone in the maintenance of seasonally appropriate body mass but not in lipectomy-induced body fat compensation in Siberian hamsters. Obes Res 3:31-41

474. Blank JL, Korytko AI, Freeman DA, Ruf TP 1994 Role of gonadal steroids and inhibitory photoperiod in regulating body weight and food intake in deer mice (Peromyscus maniculatus). Proc Soc Exp Biol Med 206:396-403

475. Madrid JA, Lopez-Bote C, Martin E 1993 Effect of neonatal androgenization on the circadian rhythm of feeding behavior in rats. Physiol Behav 53:329-335

476. Shimizu H, Ohtani KI, Uehara Y, Abe Y, Takahashi H, Tsuchiya T, Sato N, Ibuki Y, Mori M 1998 Orchiectomy and response to testosterone in the development of obesity in young Otsuka-Long-Evans-Tokushima Fatty (OLETF) rats. Int J Obes Relat Metab Disord 22:318-324

477. Gentry RT, Wade GN 1976 Androgenic control of food intake and body weight in male rats. J Comp Physiol Psychol 90:18-25

478. Clarke IJ, Rao A, Chilliard Y, Delavaud C, Lincoln GA 2003 Photoperiod effects on gene expression for hypothalamic appetite-regulating peptides and food intake in the ram. Am J Physiol Regul Integr Comp Physiol 284:R101-R115 
479. Miner JL, Della-Fera MA, Paterson JA, Baile CA 1989 Lateral cerebroventricular injection of neuropeptide Y stimulates feeding in sheep. Am J Physiol 257:R383-R387

480. Miner JL, Della-Fera MA, Paterson JA, Baile CA 1989 Lateral cerebroventricular injection of neuropeptide Y stimulates feeding in sheep. Am J Physiol 257:R383-R387

481. Sims EA, Horton ES 1968 Endocrine and metabolic adaptation to obesity and starvation. Am J Clin Nutr 21:1455-1470

482. Bernal J, Refetoff S 1977 The action of thyroid hormone. Clin Endocrinol (Oxf) 6:227-249

483. Dauncey MJ 1990 Thyroid hormones and thermogenesis. Proc Nutr Soc 49:203215

484. Haluzik M, Yakar S, Gavrilova O, Setser J, Boisclair Y, LeRoith D 2003 Insulin resistance in the liver-specific IGF-1 gene-deleted mouse is abrogated by deletion of the acid-labile subunit of the IGF-binding protein-3 complex: relative roles of growth hormone and IGF-1 in insulin resistance. Diabetes 52:2483-2489

485. Douyon L, Schteingart DE 2002 Effect of obesity and starvation on thyroid hormone, growth hormone, and cortisol secretion. Endocrinol Metab Clin North Am 31:173-189

486. Yung MC, VandeHaar MJ, Fogwell RL, Sharma BK 1996 Effect of energy balance and somatotropin on insulin-like growth factor I in serum and on weight and progesterone of corpus luteum in heifers. J Anim Sci 74:2239-2244

487. Jorgensen JO, Pedersen SA, Laurberg P, Weeke J, Skakkebaek NE, Christiansen JS 1989 Effects of growth hormone therapy on thyroid function of growth hormone-deficient adults with and without concomitant thyroxinesubstituted central hypothyroidism. J Clin Endocrinol Metab 69:1127-1132

488. Sato T, Suzukui Y, Taketani T, Ishiguro K, Masuyama T 1977 Enhanced peripheral conversion of thyroxine to triiodothyronine during hGH therapy in $\mathrm{GH}$ deficient children. J Clin Endocrinol Metab 45:324-329

489. Rezvani I, DiGeorge AM, Dowshen SA, Bourdony CJ 1981 Action of human growth hormone (hGH) on extrathyroidal conversion of thyroxine (T4) to triiodothyronine (T3) in children with hypopituitarism. Pediatr Res 15:6-9

490. Klinger B, Ionesco A, Anin S, Laron Z 1992 Effect of insulin-like growth factor I on the thyroid axis in patients with Laron-type dwarfism and healthy subjects. Acta Endocrinol (Copenh) 127:515-519 
491. Cortright RN, Koves TR 2000 Sex differences in substrate metabolism and energy homeostasis. Can J Appl Physiol 25:288-311

492. Minuto F, Barreca A, Del Monte P, Cariola G, Torre GC, Giordano G 1989 Immunoreactive insulin-like growth factor I (IGF-I) and IGF-I-binding protein content in human thyroid tissue. J Clin Endocrinol Metab 68:621-626

493. Clement S, Refetoff S, Robaye B, Dumont JE, Schurmans S 2001 Low TSH requirement and goiter in transgenic mice overexpressing IGF-I and IGF-Ir receptor in the thyroid gland. Endocrinology 142:5131-5139

494. Hanew K, Tanaka A 2001 Effect of acute elevation of IGF-I on circulating GH, TSH, insulin, IGF-II and IGFBP-3 levels in non-endocrine short stature (NESS). J Endocrinol Invest 24:1-7

495. Hussain MA, Schmitz O, Jorgensen JO, Christiansen JS, Weeke J, Schmid C, Froesch ER 1996 Insulin-like growth factor I alters peripheral thyroid hormone metabolism in humans: comparison with growth hormone. Eur J Endocrinol 134:563-567

496. Trainer PJ, Holly J, Medbak S, Rees LH, Besser GM 1994 The effect of recombinant IGF-I on anterior pituitary function in healthy volunteers. Clin Endocrinol (Oxf) 41:801-807

497. Buonomo FC, Lauterio TJ, Baile CA, Daughaday WH 1987 Effects of insulinlike growth factor I (IGF-I) on growth hormone-releasing factor (GRF) and thyrotropin-releasing hormone (TRH) stimulation of growth hormone $(\mathrm{GH})$ secretion in the domestic fowl (Gallus domesticus). Gen Comp Endocrinol 66:274-279

498. Porter BA, Refetoff S, Rosenfeld RL, De Groat LJ, Lang US, Stark O 1973 Abnormal thyroxine metabolism in hyposomatotrophic dwarfism and inhibition of responsiveness to TRH during GH therapy. Pediatrics 51:668-674

499. Chopra IJ 1976 An assessment of daily production and significance of thyroidal secretion of 3, 3', 5'-triiodothyronine (reverse T3) in man. J Clin Invest 58:32-40

500. Schimmel M, Utiger RD 1977 Thyroidal and peripheral production of thyroid hormones. Review of recent findings and their clinical implications. Ann Intern Med 87:760-768

501. Salamon E, Rowe RC, Faiman C 1989 Amiodarone-related cyclic thyroid dysfunction. CMAJ 141:1247-1249

502. Grunfeld C, Sherman BM, Cavalieri RR 1988 The acute effects of human growth hormone administration on thyroid function in normal men. J Clin Endocrinol Metab 67:1111-1114 
503. Gordon AH, Gross J, O'Connor D, Pitt-Rivers R 1952 Nature of the circulating thyroid hormone-plasma protein complex. Nature 169:19-20

504. Oppenheimer JH 1968 Role of plasma proteins in the binding, distribution and metabolism of the thyroid hormones. N Engl J Med 278:1153-1162

505. Baulieu E, Kelly PA 1990 Hormones.Hermann Publisher in Arts and Science, Paris, Chapman and Hall, New York

506. Brixen K, Nielsen HK, Bouillon R, Flyvbjerg A, Mosekilde L 1992 Effects of short-term growth hormone treatment on PTH, calcitriol, thyroid hormones, insulin and glucagon. Acta Endocrinol (Copenh) 127:331-336

507. Di Cola G, Cool MH, Accili D 1997 Hypoglycemic effect of insulin-like growth factor-1 in mice lacking insulin receptors. J Clin Invest 99:2538-2544

508. Le Roith D, Scavo L, Butler A 2001 What is the role of circulating IGF-I? Trends Endocrinol Metab 12:48-52 